\title{
Uso de drogas entre alunos da Universidade de São Paulo: 1996 versus 2001
}

Tese apresentada à Faculdade de Medicina da Universidade de São Paulo para obtenção do título de Doutor em Ciências Área de Concentração: Fisiopatologia Experimental

Orientador: Prof. Dr. Arthur Guerra de Andrade

\section{SÃO PAULO}


Para meus pais, Nicolau (in memoriam) e Vanda Para Luciana, minha mulher e companheira Para meus irmãos, Sérgio, Valeska e Pâmela 


\section{AGRADECIMENTOS}

Professor Doutor Arthur Guerra de Andrade, meu orientador neste e em outros trabalhos. Pelas brilhantes idéias e incentivo permanente.

Professor Doutor André Malbergier, pela interlocução permanente, amizade e auxílio na revisão deste material.

Doutor Sérgio Nicastri, de quem partiu o convite para a realização desta pesquisa e pelo auxílio na elaboração do projeto e sua realização.

Professora Doutora Lucia Pereira Barroso pelo auxílio na realização da análise estatística e contribuições na definição dos métodos de análise adotados.

Professor Doutor Wallace Mandell meu orientador na Universidade Johns Hopkins durante o programa Hubert $\mathrm{H}$. Humphrey. Pela ampliação da minha compreensão da problemática do uso de drogas na atualidade com a qual esta pesquisa pretende contribuir.

Professor Doutor Julio Litivoc pelas primeiras noções de epidemiologia e ajuda no cálculo da amostra.

Doutora Sueli de Queiroz pela generosidade com que me passou sua experiência que muito ajudou na realização desta pesquisa.

Celi de Lima Jove e Ednei Rufino de Souza, funcionários do GREA, companheiros valiosos, sempre dispostos e capazes.

Roberta Kimie Yamamoto e Daniela Chiaradia pela pronta ajuda sempre fornecida e apoio logístico.

Psicóloga Thaís H. M. Laranjo pelos contatos com os funcionários da USP e interface com as comissões do Produsp.

Companheiros que trabalharam como Supervisores de Campo, psicólogas Silvia Maria de Carvalho e Betina Leme e Auxiliares de Pesquisa, cuja dedicação, criatividade e perseverança tornaram possível este trabalho.

Funcionários das diversas unidades da USP, por todo o apoio fornecido.

Alunos participantes da pesquisa pela boa vontade, idéias e incentivo para a realização da pesquisa.

Fundação de Amparo à Pesquisa do Estado de São Paulo - FAPESP - pelo apoio financeiro que tornou viável a execução desta pesquisa. 
Esta dissertação está de acordo com:

Universidade de São Paulo. Faculdade de Medicina. Serviço de Biblioteca e Documentação. Guia de apresentação de dissertações, teses e monografias. Elaborado por Anneliese Carneiro da Cunha. São Paulo: Senviço de Biblioteca e Documentação, 1996. 


\section{SUMÁRIO}

Lista de Anexos

Lista de Abreviaturas

Lista de Tabelas

Resumo

Summary

\section{INTRODUÇÃO}

1.1 Conceitos básicos sobre do uso de drogas.....................................................1

1.2 A eterna busca do êxtase .........................................................................

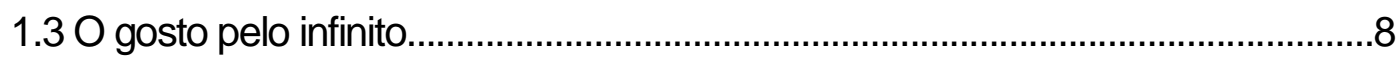

\section{REVISÃO DA LITERATURA}

$2.1 \mathrm{O}$ uso de drogas no mundo...........................................................................11

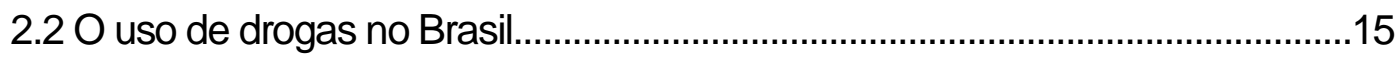

2.3 Estudos epidemiológicos transversais sobre o uso de drogas

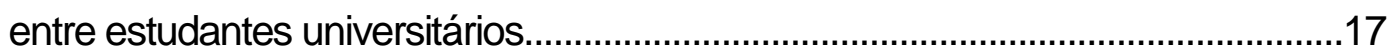

2.4 Fatores de risco para o uso de drogas entre

estudantes universitários...............................................................22

$2.5 \mathrm{O}$ uso de drogas entre estudantes da USP...................................................25

\section{OBJETIVOS E HIPÓTESES}

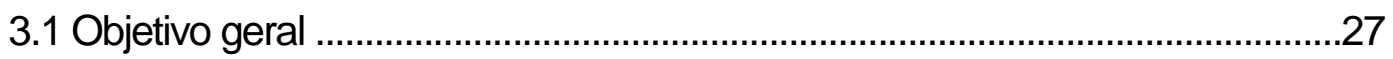

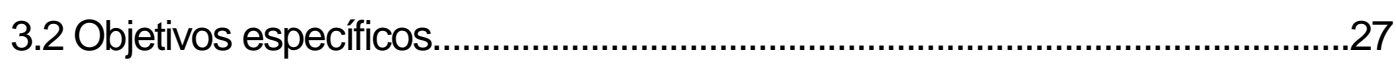

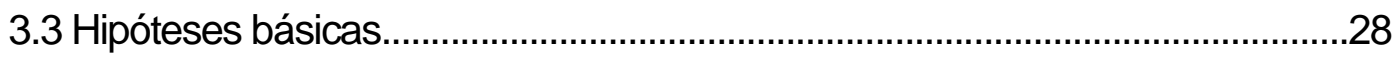

\section{CASUÍSTICAS E MÉTODOS}

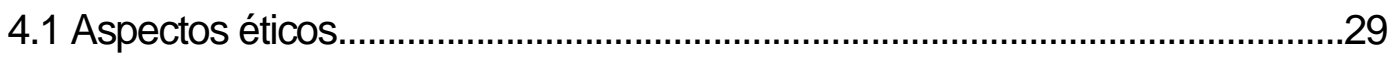

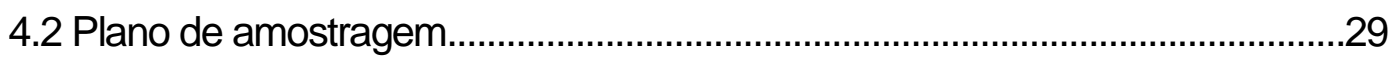




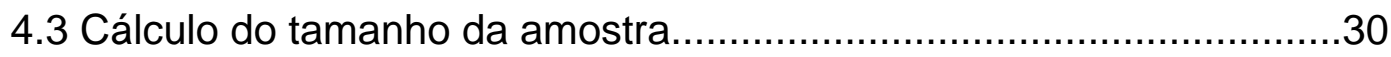

4.4 Realização do sorteio da amostra....................................................32

4.5 Método de coleta de dados

4.5.1 Cartas envidas para as unidades da USP .............................................34

4.5.2 Recrutamento e treinamento dos auxiliares de pesquisa.........................34

4.5.3 Material para a coleta de dados...................................................................

4.5.4 Confecção dos questionários, Termos de Consentimento e cartões

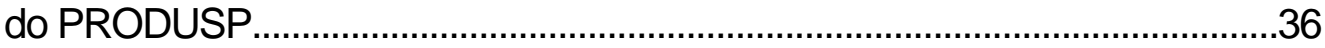

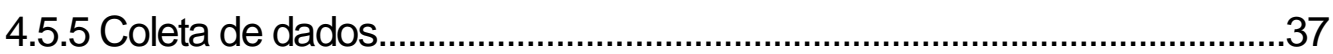

4.5.5.1 Problemas encontrados ...............................................................39

4.5.6 Reposição da amostra...........................................................................40

4.5.7 Visitas de supervisão de campo................................................................41

4.6 Método de análise de dados

4.6.1 Análise estatística dos dados..................................................................42

4.6.2 Procedimentos para a construção dos modelos

de regressão logística........................................................................................4

\section{RESULTADOS}

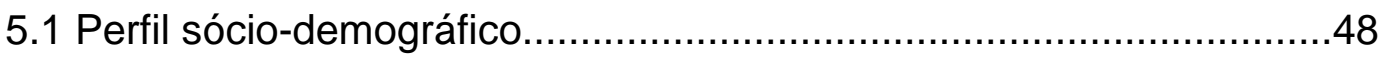

5.2 Informações e atitudes sobre o uso de drogas ..................................................56

5.3 Uso de drogas entre os estudantes................................................................61

5.3.1 Resultados comparando as áreas de Biológicas e Humanas.................63

5.3.2 Resultados comparando as áreas de Humanas e Exatas......................64

5.3.3 Resultados comparando as áreas de Biológicas e Exatas.......................64

5.3.4 Resultados comparando Homens e Mulheres..........................................65

5.3.5 Resultados comparando os períodos Noturno e Diurno............................66

5.3.6 Comparação entre a pesquisas realizadas em 1996 e 2001 ....................66 
5.3.7 Modelos de regressão logística................................................................71

5.3.7.1 Uso corrente de álcool (últimos 30 dias)...................................71

5.3.7.2 Uso recente de drogas ilegais (últimos 12 meses)...................75

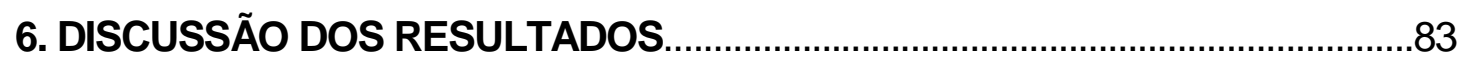

6.1 Dados sócio-demográficos..........................................................................

6.2 Dados sobre opinião quanto ao uso de drogas e suas

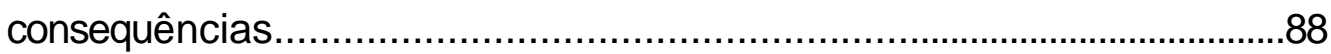

6.3 Dados sobre o uso de drogas e comparações

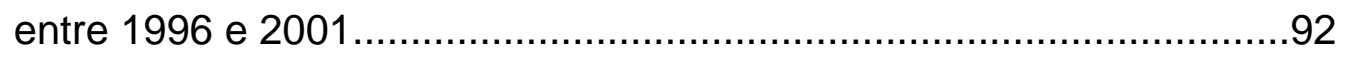

6.4 Comparações do uso de drogas entre alunos das

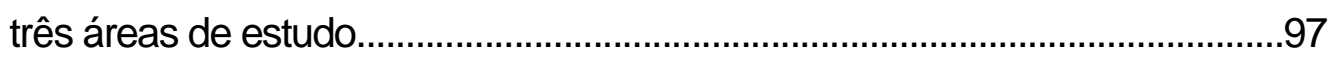

6.5 Comparações do uso de drogas entre alunos

do sexo masculino e feminino............................................................................98

6.6 Variáveis ambientais dos modelos de regressão logística para o uso corrente de álcool.......................................................................100

7. CONCLUSÕES.

8. ANEXOS

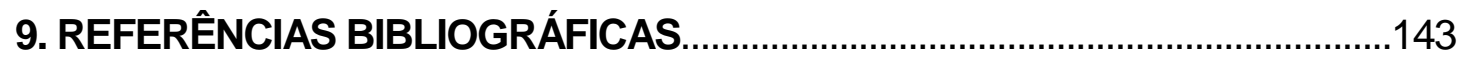




\section{Lista de Anexos}

Anexo A - Parecer da Comissão de Ética para Análise de Projetos de Pesquisa da Diretoria Clínica do Hospital das Clínicas da Faculdade de Medicina da Universidade de São Paulo

Anexo B - Termo de Consentimento Pós-Informação..................................106

Anexo C - Questionário...........................................................................................109

Anexo D - Tabela comparativa das áreas de Biológicas, Exatas e Humanas..........123

Anexo E - Tabela comparativa do uso de drogas entre estudantes do sexo masculino e feminino.

Anexo F - Tabela comparativa do uso de drogas entre estudantes do noturno e diurno.

Anexo G - Trabalhos e apresentações decorrentes desta tese 140 


\section{Lista de Abreviaturas}

ECA Escola de Comunicações e Artes

FAU Faculdade de Arquitetura e Urbanismo

FD Faculdade de Direito

FEA Faculdade de Economia, Administração e Contabilidade

FE Faculdade de Educação

FFLCH Faculdade de Filosofia, Letras e Ciências Humanas

EP Escola Politécnica

IAG Instituto Agronômico e Geofísico

IF Instituto de Física

IGc Instituto de Geociências

IQ Instituto de Química

IME Instituto de Matemática e Estatística

EEFE Escola de Educação Física

EE Escola de Enfermagem

FCF Faculdade de Ciências Farmacêuticas

FM Faculdade de Medicina

FMVZ Faculdade de medicina Veterinária e Zootecnia

FO Faculdade de Odontologia

FSP Faculdade de Saúde Pública

IB Instituto de Biociências

IP Instituto de Psicologia

OMS Organização Mundial de Saúde

CID Classificação internacional de doenças

DSM Manual diagnóstico e estatístico de transtornos mentais

ONU Organização das Nações Unidas

PRODUSP Programa de tratamento e prevenção ao uso de drogas da USP

USP Universidade de São Paulo

UNESP Universidade Estadual Paulista 


\section{Lista de Tabelas}

Tabela 1 - Distribuição dos alunos sorteados por áreas e unidades dos cursos de graduação da USP.

Tabela 2 - Total de questionários sorteados e aplicados por unidade e área.

Tabela 3 - Porcentagem de perdas amostrais por unidade onde este total foi superior a $20 \%$ do total de alunos inicialmente sorteado.

Tabela 4 - Distribuição dos questionários válidos por área.

Números absolutos e porcentagem.

Tabela 5 - Distribuição dos questionários válidos por unidade.

Números absolutos e porcentagem.

Tabela 6 - Distribuição dos questionários válidos por ano de ingresso.

Números absolutos e porcentagem.

Tabela 7 - Distribuição dos questionários válidos por ano que cursou em 2000.

Números absolutos e porcentagem.

Tabela 8 - Distribuição dos questionários válidos por período do curso.

Números absolutos e porcentagem.

Tabela 9 - Distribuição dos questionários válidos por sexo.

Números absolutos e porcentagem.

Tabela 10 - Distribuição dos questionários válidos por idade.

Números absolutos e porcentagem.

Tabela 11 - Distribuição dos questionários válidos por estado civil.

Números absolutos e porcentagem.

Tabela 12 - Distribuição dos questionários válidos ter ou não filhos.

Números absolutos e porcentagem.

Tabela 13 - Distribuição dos questionários válidos por situação de moradia.

Números absolutos porcentagem.

Tabela 14 - Distribuição dos questionários válidos por ter ou não religião.Números absolutos e porcentagem....53

Tabela 15 - Distribuição dos questionários válidos por tipo de religião. Números absolutos e porcentagem

Tabela 16 - Distribuição dos questionários válidos por prática ou não da religião. Números absolutos e porcentagem 
Tabela 17 - Distribuição dos questionários válidos por exercício de alguma atividade remunerada por período maior que um mês nos últimos 6 meses. Números absolutos e porcentagem

Tabela 18 - Distribuição dos questionários válidos por grau de escolaridade do pai. Números absolutos e porcentagem......54

Tabela 19 - Distribuição dos questionários válidos por grau de escolaridade da mãe. Números absolutos e porcentagem....55

Tabela 20 - Distribuição dos questionários válidos por renda familiar em número de salários mínimos. Números absolutos e porcentagem

Tabela 21 - Distribuição dos questionários válidos pelos motivos para o uso de drogas (exceto álcool e tabaco) pela primeira vez. Números absolutos e porcentagem. 56

Tabela 22 - Distribuição dos questionários válidos pelo tipo de pessoa que introduziu no uso de drogas (exceto álcool e tabaco). Números absolutos e porcentagem.

Tabela 23 - Distribuição dos questionários válidos por ter experimentado drogas (exceto álcool e tabaco) sem prescrição médica antes de entrar na universidade. Números absolutos e porcentagem.

Tabela 24 - Distribuição dos questionários válidos por tipo de drogas experimentado (exceto álcool e tabaco) sem prescrição médica antes de entrar na universidade.

Números absolutos e porcentagem.

Tabela 25 - Distribuição dos questionários válidos por motivos para o uso freqüente de drogas. Números absolutos e porcentagem.

Tabela 26 - Distribuição dos questionários válidos por tipo de pessoa com quem usa com mais freqüência drogas. Números absolutos e porcentagem.

Tabela 27 - Distribuição dos questionários válidos pelo tipo de interferência que o uso freqüente de drogas causa. Números absolutos e porcentagem.

Tabela 28 - Distribuição dos questionários válidos por envolvimento em algum acidente de carro após o consumo de álcool e drogas,nos últimos 12 meses. Números absolutos e porcentagem 
Tabela 29 - Distribuição dos questionários válidos por uso de álcool por algum membro da família com prejuízos ao convívio social, familiar e profissional nos últimos 12 meses.

Números absolutos e porcentagem

Tabela 30 - Distribuição dos questionários válidos por uso freqüente de drogas por algum membro da família ou amigos. Números absolutos e porcentagem

Tabela 31 - Distribuição dos questionários válidos por tipo de droga utilizada na vida. Números absolutos e porcentagem.

Tabela 32 - Distribuição dos questionários válidos por tipo de droga utilizada nos últimos 12 meses. Números absolutos e porcentagem.62

Tabela 33 - Distribuição dos questionários válidos por tipo de droga utilizada nos últimos 30 dias. Números absolutos e porcentagem....63

Tabela 34 - Drogas que apresentaram diferença estatisticamente significante a partir da comparação entre a proporções de alunos que fizeram uso de alguma droga na vida por tipo de droga, área de estudo e total das pesquisas realizadas em 1996 e 2001. (Intervalo de confiança 95\%).

Tabela 35 - Drogas que apresentaram diferença estatisticamente significante a partir da comparação entre a proporções de alunos que fizeram uso de alguma droga na vida por tipo de droga, área de estudo e total das pesquisas realizadas em 1996 e 2001. (Intervalo de confiança 95\%).

Tabela 36 - Drogas que apresentaram diferença estatisticamente significante a partir da comparação entre a proporções de alunos que fizeram uso de alguma droga na vida por tipo de droga, área de estudo e total das pesquisas realizadas em 1996 e 2001. (Intervalo de confiança 95\%).

Tabela 37 - Prevalências do uso de drogas na vida, nos últimos 12 meses e nos últimos 30 dias por alunos universitários da USP e da UNESP.

Tabela 38 - Comparação entre as pesquisas de 1996 e 2001 sobre as opiniões sobre uso regular de diversas drogas.

(Intervalo de confiança 95\%).

Tabela 39 - Comparação entre as pesquisas de 1996 e 2001 sobre as opiniões sobre experimentar diversas drogas. (Intervalo de confiança 95\%).

Tabela 40 - Modelo de regressão logística final para uso de álcool no último mês. 
Tabela 41 - Modelo de regressão logística final para o uso de drogas ilegais nos últimos 12 meses.. 


\section{RESUMO}

STEMPLIUK, V.A. Uso de drogas entre alunos da Universidade de São Paulo: 1996 versus 2001. São Paulo, 2004. 150p. Tese (Doutorado) - Faculdade de Medicina, Universidade de São Paulo.

Esta tese apresenta os dados sobre as atitudes e o uso de álcool e outras drogas pelos alunos de graduação da Universidade de São Paulo - USP - no campus São Paulo, matriculados no ano de 2001 e os compara aos dados obtidos em 1996.

Os dois estudos seguiram as mesmas metodologias de amostragem e coleta de dados. Os alunos foram randomicamente selecionados de acordo com suas áreas de estudo: Biológica, Exatas e Humanas. Uma amostra de 2837 estudantes respondeu a um questionário anônimo e de auto-preenchimento desenhado de modo a levantar o uso na vida, nos últimos 12 meses e nos últimos 30 dias de drogas legais e ilegais.

Para a comparação entre as duas pesquisas foram construídos intervalos de confiança (95\%) para a diferença entre as prevalências para cada substância investigada nos dois momentos. O coeficiente de confiança foi controlado como sugerido no Método Bonferroni. O mesmo procedimento foi utilizado para comparar as prevalências entre as três áreas de estudo, sexo e período de curso.

Para calcular os fatores de risco para o uso corrente de álcool e recente de drogas ilegais foram construídos dois modelos de regressão logística. Primeiro foi aplicado o teste qui-quadrado para cada uma das variáveis investigadas. Aquelas cujo teste apresentou resultado de $p$ superior a 0,05 foram sendo retiradas dos modelos através do método backward. Ao final foram construídos dois modelos reunindo todas a variáveis restantes, um para uso de álcool e outro para uso de drogas ilegais.

Observa-se que as principais drogas usadas pelos estudantes são: álcool, tabaco, maconha, inalantes e anfetaminas. Quando as drogas ilegais são agrupadas em uma única categoria, observa-se que as prevalências de uso são: na vida: 45,14\%, nos últimos 12 meses: $31,20 \%$ e nos últimos 30 dias: $21,77 \%$.

A comparação entre 1996 e 2001, mostrou que, nestes últimos seis anos, houve um aumento significativo de uso na vida de: álcool, tabaco, maconha, alucinógenos, anfetaminas, anti-colinérgicos, inalantes, barbitúricos e drogas ilegais; de uso nos últimos 12 meses de: maconha, alucinógenos, anfetaminas, inalantes e drogas ilegais; e de uso nos últimos 30 dias de: maconha, anfetaminas, inalantes e drogas ilegais.

Estes dados reforçam a necessidade do desenvolvimento de atividades de prevenção do abuso e de redução de danos decorrentes do uso de álcool e outras drogas na tentativa de reduzir a vulnerabilidade observada entre grupos específicos de alunos. Fatores pessoais e ambientais demonstraram estar associados a variações na forma e freqüência de utilização de substâncias psicoativas pelos alunos de graduação da USP, constituindo situações de maior ou menor risco para sua saúde. 


\section{SUMMARY}

STEMPLIUK, V.A. Drug use among University of São Paulo students: 1996 versus 2001. São Paulo, 2004. 150p. Tese (Doutorado) - Faculdade de Medicina, Universidade de São Paulo

This dissertation presents data about atitudes towards alcohol and other drug use as well as alcohol and other drug use behaviors among undergraduate stundents from the University of São Paulo, Brazil (São Paulo campus) in 2001 and compares these data with similar data obtained in 1996.

In both studies the same sample calculation and data colection methodologies were applied. The students were randomly selected by field of study: biological sciences, exact sciences and liberal arts. In 2001 the response rate was $83.61 \%$, 2837 students responded an anonymous and self-response questionnaire designed to obtain information about lifetime, past-12month and past-30day drug use prevalence.

In order to compare the two studies Confidence Interval (95\%) were constructed for the difference between prevalence of each drug use at the two moments. The confidence coefficient was controlled by the Bonferroni Method. Similar procedure was utilized to compare drug use prevalence between different fields of study, male and female gender, and year of college study.

A logistic regression model was applied to calculate the risk factors for current alcohol use and recent illegal drug use. The chi-square test was applied for each one of the variables and those tests yielding $p>0.05$ were eliminated from the model by the backward method. After the appropriate adjustments a single model for alcohol and other for illegal drugs was constructed putting together all the remaining variables. In 2001 the primary drugs used by the students were: alcohol, tobacco, marijuana, inhalants, hallucinogens and amphetamines. The prevalence of any illegal drug use joined in one category was: lifetime: $45.14 \%$, past- 12 month: $31.20 \%$ and past-30days: $21.77 \%$.

The comparison between the two surveys showed that drug use increased in the past six years. The lifetime prevalence of alcohol, tobacco, marijuana, inhalants, hallucinogens, amphetamines, anticolinergics, barbiturates and illegal drugs were statistically significantly higher in 2001 than in 1996. Similar results were found for: past-12month prevalence of: marijuana, inhalants, hallucinogens, amphetamines and illegal drugs; past-30day prevalence: marijuana, inhalants, amphetamines and illegal drugs.

These data reinforce the need of developing drug use and abuse prevention activities and harm reduction strategies in order to reduce the students' vulnerability for drug use and its consequences. Personal and environmental factors showed a positive association with drug use and could help us to understand the differences in type of drug, frequency of utilization and adverse consequence observed among the students. 


\section{INTRODUÇÃO}

\subsection{Conceitos básicos sobre o uso de drogas}

É necessário, desde o início, definir dois conceitos que são fundamentais para este trabalho: substâncias psicoativas e uso de drogas. Antes, no entanto, observemos como a Organização Mundial de Saúde (OMS) define a palavra droga:

Termo de uso variado. Em geral, refere-se a qualquer substância com potencial de prevenir ou curar doenças e aumentar o bem-estar físico ou mental. Em farmacologia, refere-se a qualquer agente químico que altera os processos bioquímicos e fisiológicos de tecidos ou organismos. (BERTOLOTE, 1997).

Dentre estas substâncias, as que interessam particularmente a esta pesquisa são as drogas psicotrópicas ou psicoativas, que são definidas como aquelas que atuam sobre os mecanismos de funcionamento do Sistema Nervoso Central. As drogas psicoativas alteram o estado emocional, as sensações, o pensamento e a consciência, podendo ou não propiciar o estabelecimento de uma síndrome de dependência ou produzir transtornos mentais e comportamentais (CID 10, 1993. DSM IV, 1995). O interesse desta pesquisa recaiu sobre as drogas psicoativas que possuem potencial de abuso. Segundo Gold (1997), todas as drogas com potencial de abuso apresentam algumas características em comum como o fato de serem voluntariamente auto-administradas por animais, agirem de maneira a aumentar agudamente os mecanismos de recompensa do cérebro através da produção de efeito agudo agradável, possuem suas propriedades de reforço significativamente atenuadas pelo bloqueio do sistema cerebral de reforço, parecem capazes de alterar a liberação de dopamina nos núcleos acubens e produzem um aumento da espera da oportunidade de animais se auto-administrarem a droga o que nos seres humanos se caracteriza pelos pensamentos, vontade e comportamentos recorrentes de usar a droga. 
Estas drogas são as que potencialmente causam maiores danos aos indivíduos e à sociedade como um todo por seu uso abusivo e decorrentes consequiências. Apesar de potencialmente danosas, muitas substâncias psicoativas possuem também efeitos terapêuticos, o que justifica sua classificação internacional como substâncias de produção, distribuição e uso controlados desde 1961 em 4 diferentes níveis de acordo com seus potenciais de abuso e dependência, efeitos físicos, psíquicos e comportamentais e qualidades terapêuticas (UNODC, 2004). Como afirma Ray (1990), as drogas em si não podem ser consideras boas ou ruins, estas qualidades se expressam na interação com os indivíduos e variam de acordo com as características pessoais, dosagem, frequiência e forma de utilização e o contexto sócio-cultural e histórico de onde provêm os sentidos mais amplos e legais destas substâncias.

Um segundo conceito de importante definição é o de uso de drogas. Bertolote (1997), sistematizou os diversos usos da seguinte forma: uso experimental: simplesmente os primeiros episódios de uso, extremamente infreqüentes ou não persistentes; uso recreativo: uso em circunstâncias sociais ou relaxantes, sem implicações de outros problemas relacionados; uso controlado: refere-se à manutenção de um uso regular, não compulsivo e que não interfere com o funcionamento habitual do indivíduo; e o uso social: que pode ser entendido como o uso em companhia de outras pessoas e de maneira socialmente aceitável. As definições de uso nocivo ou abuso e dependência são caracterizadas no CID 10 (1993), e no DSM IV (1995), e como não constituem objeto desta investigação, não serão definidos neste trabalho.

Os conceitos apresentados até o momento fundamentam o desenvolvimento desta pesquisa, mas, para sua melhor compreensão e interpretação dos resultados obtidos, uma outra perspectiva deve ser recordada. Um outro modo de abordar as relações indivíduo/droga é enfatizar o contexto sócio-cultural específico onde esta relação se estabelece. Gilberto Velho (1994), comentando estas outras variáveis que constituem o fenômeno, afirma: 
A contribuição da antropologia em mostrar com existem $n$ maneiras

de utilizar as substâncias, em função de variáveis culturais e

sociológicas. Estas não só se somam, como complexificam as

distinções que possam se registradas ao nível da análise

bioquímica(...). Insistimos que para a compreensão do fenômeno das

drogas, assim como qualquer outro, o passo indispensável é sua

contextualização. Todas as tentativas de explicações genéricas,

baseadas em premissas fisiológicas e psicológicas, tenderam a ficar no

nível da rotulação e da estigmatização. Assim o fenômeno cultural

apresenta a sua inevitável dimensão de poder.(VELH0, 1994, p. 24-7).

Ou seja, o autor recorda que o uso de drogas deve sempre ser enxergado contra o pano de fundo da cultura e da sociedade. A importância destes aspectos é atestada pelos vários contornos sociais que este fenômeno tem assumido em todo o mundo ao longo da história. Discutir-se-á dois modos expressivos desta interação indivíduo, droga e sociedade, que demonstram esta diversidade: o uso religioso e o uso estético de drogas.

\subsection{A eterna busca do êxtase}

O êxtase religioso foi a forma que o homem popularmente encontrou, desde os temos primordiais, de romper as barreiras da realidade concreta e adentrar o mundo espiritual. Lá, era onde ele encontrava respostas às suas indagações mais básicas e essenciais e ajuda para lidar com seus medos, suas doenças, suas perdas e catástrofes cotidianas. O uso de certas plantas e animais com efeitos psicoativos era um dos instrumentos utilizados para a obtenção deste estado e êxtase. O uso da droga dava-se neste contexto muito específico, respaldado pela crença coletiva e pelos rituais religiosos.

Tradicionalmente, a pessoa a que era capaz de atingir o êxtase e realizar esta comunicação era o Xamã. Como afirma Eliade (1998a), "Em toda a imensa área que compreende o centro e o norte da Ásia, a vida mágico-religiosa da sociedade gira em 
torno do Xamã..." Uma primeira definição desse fenômeno complexo, e possivelmente a menos arriscada, será: xamanismo=técnica do êxtase" (p. 16).

Claro está que o uso de drogas neste contexto em nada tem a ver com o uso que se faz contemporaneamente e que se constitui em um problema de Saúde Pública. No passado, e na atualidade em comunidades muito específicas - povos indígenas e religiosos - o uso de drogas é um instrumento de obtenção do êxtase e parte do arsenal mágico utilizado na cura das doenças. Possui, portanto, todo um sistema de valores sociais e sentidos culturais compartilhados que o tornam um fenômeno aceito e valorizado dentro destas sociedades.

Um exemplo é fornecido por Eliade (1998a), ao relatar uma cerimônia religiosa em que o tabaco é utilizado:

Em geral são iniciados seis rapazes ao mesmo tempo. Vivem completamente isolados numa cabana construída só para essa finalidade e coberta com folhas de palmeira. Exige-se deles certo trabalho manual: cuidam da plantação de tabaco do mestre-iniciador e constroem com um tronco de cedro um banco em forma de jacaré (...). Seis moças providenciam diariamente o suco de tabaco que eles devem beber em grande quantidade(...). Durante todo o tempo que dura a instrução o jejum é quase absoluto: os aprendizes fumam continuamente e mascam folhas de tabaco e bebem o suco de tabaco. Após as danças extenuantes da noite, com a ajuda do jejum e da intoxicação, os aprendizes são preparados para a viagem extática (p. 150).

Eliade (1998a), cita os costumes funerários discutidos por Heródoto, recordando que entre os gregos, o uso de plantas alucinógenas se dava também neste contexto religioso. Após os funerais eram feitas as purificações nas quais jogavam-se folhas de maconha sobre as pedras em brasa e respirava-se a fumaça. O culto dos mortos, a utilização do cânhamo, a estufa e ou "uivos" constituem, na verdade, um conjunto religioso específico, cujo objetivo só podia ser o êxtase“. (p. 429).

O ópio e a maconha são conhecidos há milhares de anos pela humanidade. Segundo uma antiga lenda da Índia, a cannabis foi um presente dos deuses para a 
humanidade para que esta pudesse obter prazer, valor e desejos sexuais potencializados (SCHULTES \& HOFMANN, 2000, p. 92). Estes autores estimam que esta relação com estas duas plantas existe há pelo menos 10.000 anos, ou seja, desde o período neolítico. (SCHULTES \& HOFMANN, 2000, p. 92).

Por ser um fenômeno muito antigo e presente na história da humanidade em diferentes culturas e épocas, o uso de substâncias psicoativas nem sempre se deu somente dentro do contexto religioso e, mesmo dentro dele, parece ter sofrido historicamente mudanças importantes. O fato de a substância ser utilizada dentro dos rituais, provavelmente funcionava também como um controle social. Ao privilegiar o uso coletivo ao individual, compartilhava-se os benefícios da droga e controlava-se seu dano.

Nestes exemplos do uso religioso fica claro que é o conjunto de valores culturais associados a estas substâncias que Ihes vão atribuir os sentidos. Em nossa sociedade também é assim, sobre elas compartilhamos variados sentidos que estão relacionados a suas variadas formas de utilização.

No entanto, apesar desta positividade atribuída às substâncias, há também o receio concomitante de que seu uso domine e degrade os valores humanos. Que a relação se transforme, e o uso destas substâncias passe a ocupar o lugar central e não o de veículo potencializador. As conclusões de Eliade (1998a), de que há uma distinção entre o êxtase conseguido através dos meios rigorosos de iniciação e o êxtase provocado pelo uso das plantas alucinógenas parecem expressar que esse receio.

Os narcóticos são apenas substitutos vulgares do transe "puro". Já tivemos oportunidades de constatar que, entre vários povos siberianos, as intoxicações (álcool e tabaco etc.) são inovações recentes e denotam uma espécie de decadência da técnica xamânica. Tenta-se imitar, pela embriaguez narcótica, um estado espiritual não mais acessível de outro modo (...). Também cabe lembrar o papel do haxixe e de outros 
narcóticos na mística islâmica, embora os santos mais puros jamais tenham recorrido a tais métodos" (ELIADE, 1998a, p. 436-7).

Outro autor registrou em seus escritos os antigos usos das substâncias psicoativas associadas a atos de violência e dominação. Marco Pólo, o famoso viajante Veneziano do século XVI, relata em seu "Livro da Maravilhas", uma lenda sobre Aladino, o velho da Montanha, que possuía um exército de guerreiros a seu dispor que, ao realizar seus desígnios de vingança e assassinatos, ganhavam como prêmio viver um jardim maravilhoso que se assemelhava ao paraíso descrito por Maomé, onde maconha e o haxixe faziam parte do conjunto de "dádivas" com que eram gratificados. "Estes assassinos, eram os hashash, ou hashish, a droga que seria utilizada pelos membros da seita ismaelita fundada em 1090 por Hassan Sabbah". (POLO, 1999, p. 101).

Uma outra categoria de substâncias psicoativas que estão na própria origem de noção de humanidades são as bebidas alcoólicas. O vinho parece ter tido sua origem nas antigas terras da Geórgia e Armênia e a viticultura origina-se do período entre 7000 e 5000 a.C.. Foram os egípcios que primeiro registraram todos os passos da elaboração do vinho com hieróglifos datados de 5000 a.C. Mas foram os gregos e os romanos quem mais contribuíram para que o vinho ficasse indissociavelmente ligado à humanidade e a seus deuses. "A vinha era identificada pelos paleorientais à 'planta de vida', e o sinal sumério para a vida era originariamente uma folha de videira". (ELIADE, 1998b, p. 230).

Enfim, como resumem Schultes e Hofmam (2000), "Em todo o mundo primitivo, nas Américas, na Europa, na Ásia e na África, o homem vem se utilizando de substâncias psicotrópicas há milênios e este uso tem sido considerado central dentro destas culturas" (p. 92). Ao longo da história, esse consumo foi ocupando 
espaço em diferentes contextos culturais, ganhando aceitação e proibição, em diversos países. (MASUR, 1978). 


\subsection{0 gosto pelo infinito.}

As expansões européias que começam a ocorrer na idade média e se incrementam com as grandes navegações, possibilitaram o contato dos europeus com as plantas psicoativas utilizadas tradicionalmente pelas culturas chamadas primitivas. Assim foi com o ópio e com o cânhamo, que passaram a ser comercializados pelos europeus e, paulatinamente, a serem objetos de uso e de pesquisas nos mais diversos campos. Intelectuais, cientistas e artistas da Europa passaram a usar, pesquisar e refletir sobre os efeitos psicoativos destas substâncias. É o caso de Charles Baudelaire, que juntamente com poetas, pintores e jovens intelectuais franceses de meados do séc. XIX reunia-se no "Club dês Hachichins", no Hôtel Pimodan, em Paris. A partir destes famosos encontros, o autor reflete sobre o êxtase provocado pelas drogas e discute seus efeitos sobre o caráter, o pensamento e o processo criativo. Lança, em 1861, o livro Paraísos Artificiais, um dos primeiros clássicos sobre o tema, onde se encontra um exemplo desta atividade reflexiva inspirada pelos efeitos do uso de drogas.

\footnotetext{
È, na verdade, ao fim deste período de embriaguez que se manifesta uma sagacidade, uma acuidade superior a todos os sentidos. $\mathrm{O}$ olfato, a visão, a audição, o tato participam igualmente deste processo. Os olhos alcançam o infinito. $\mathrm{O}$ ouvido percebe sons quase inaudíveis no centro do maior tumulto. È aí então que começam a alucinações. Lentamente, sucessivamente, os objetos ganham aparências estranhas; deformamse e se transformam. (BAUDELAIRE, 1982. p.23)
}

Ele percebe, no entanto, que, além do prazer e da modificação perceptiva, o uso exagerado destas substâncias pode ser prejudicial. “... duas características do ópio são perfeitamente aplicáveis ao haxixe; tanto em um quanto em outro, a inteligência, ainda há pouco livre, torna-se escrava"' (BAUDELAIRE, 1982. p. 30). Apesar do encantamento com os efeitos impressionantes sobre a sensibilidade e a percepção, o autor nos faz uma advertência. 
E se ainda, à custa de sua dignidade, de sua honestidade e de seu livre arbítrio, o homem pudesse tirar do haxixe grandes benefícios espirituais, fazer dele uma espécie de máquina de pensar, um instrumento fecundo?. A magia os engana e acende para eles uma falsa felicidade e uma falsa luz; enquanto nós, poetas e filósofos, regeneramos nossa alma pelo trabalho sucessivo e pela contemplação; pelo exercício assíduo da vontade e pela nobreza permanente da intenção, criamos para nosso uso um jardim de beleza verdadeira. (BAUDELAIRE, 1982, p. 40-1).

Novamente, depara-se aqui, com a mesma ressalva feita por Eliade (1998a). Há uma diferença entre o que se consegue construir através da genialidade, do esforço criativo e o que vem através da ilusão do êxtase psicoativo.

Um outro intelectual marcou a literatura mundial com um livro que se tornou também um clássico sobre o relato das experiências do uso de substâncias psicoativas. O livro chama-se Confissões de um Comedor de Ópio (1988). Seu autor, Thomas de Quincey, foi usuário de ópio por quase 50 anos, e em suas confissões, percebe-se claramente as diversas fases desse relacionamento intenso com a droga; desde o deslumbramento das primeiras experiências, até a desilusão e decadência moral do período da dependência.

É preciso compreender estes movimentos relatados por Quincey, Baudelaire e outros intelectuais da época, dentro de um momento cultural da Europa, onde os principais motivos para a busca das drogas psicotrópicas eram o alívio das dores físicas e espirituais e a busca de respostas para os questionamentos artísticos e estéticos dos meados do século XIX. Estas duas características constituem a concepção moderna do êxtase provocado pelos psicotrópicos: "Trata-se de uma meditação dentro do mecanismo da imaginação"(QUINCEY, 1988, p. 14).

Sobre este envolvimento profundo com a droga este autor escreve: "Esta é a doutrina da verdadeira igreja na questão do ópio, uma igreja da qual suponho ser o único membro". (p. 51) e mais à frente em seu livro escreve: "Assim sendo, repito, no momento em que comecei a tomar ópio diariamente, não pude fazer outra coisa. 
Nada que conseguisse quebrar o hábito, mesmo porque me parecia que todos os esforços que fiz foram inúteis por não me terem levado muito longe". (QUINCEY, 1988, p. 59). Êxtase e degradação, a ambigüidade que parece estar presente em todos estes contextos, os dois grandes limites do humano.

Mais tardiamente, Walter Benjamin (1984), escreveu sobre os efeitos do haxixe, droga que experimentou algumas vezes. $O$ relato que se segue é sobre a experiência da qual participou em 1932, em lbiza, na casa de um amigo. O autor escreve:

Para melhor compreender a enigmática felicidade proporcionada pelo haxixe, seria preciso evocar o fio de Ariadne. Quanto prazer pode caber no simples ato de desenrolar um novelo! Profundo parentesco entre esse prazer e o da droga, assim como o da criação. (BENJAMIN, 1984, p. 33).

Com estes exemplos acredita-se que tenha ficado claro que o fenômeno do uso de drogas pela humanidade é extremamente complexo e intensamente imbricado com os anseios humanos mais profundos. Como fenômeno cultural, não poderia deixar de expressar a ambigüidade dos seres humanos ao lidar com suas necessidades e limites. O fascínio que o uso das substâncias psicoativas exerceu e exerce sobre a humanidade, como vimos, foi mudando de significado ao longo da história e continua a se transformar cotidianamente. Vivemos um momento histórico em que se observam variados tipos de uso, mas que possuem em comum, a busca do prazer, da identidade social, do alivio das tensões cotidianas, de algo eficaz que propicie alterações psíquicas rápidas e dêem uma sensação de bem estar. $\mathrm{Na}$ atualidade, sentir os efeitos da droga, aliviar as tensões e estresse, integrar-se socialmente, são os principais motivos apontados para o uso de drogas, na atualidade (ANDRADE et al., 1996. KERR-CORREA et al., 2001, LANIER et al., 2001, SWADDI, 1999, LEEMAN, 2001). 


\section{REVISÃO DA LITERATURA}

$\mathrm{Na}$ atualidade, o uso de drogas transformou-se num fenômeno global e altamente lucrativo. Milhões de pessoas consumem os mais diversas tipos de substâncias psicoativas e praticamente todos os países de mundo. Para compreender os dados relativos aos estudantes da USP, é interessante conhecer as estatísticas dos contextos mais amplos em que estes estudantes se inserem.

\subsection{Uso de drogas no mundo}

Segundo os dados da ONU (Organização das Nações Unidas), estima-se que, aproximadamente, 200 milhões de pessoas, com 15 ou mais anos de idade, fizeram uso de drogas ilícitas entre 2000 e 2001. Isso corresponde a 4,7\% da população mundial nesta faixa etária (GLOBAL ILLICIT DRUG TRENDS, 2003). As drogas ilícitas mais utilizadas foram: maconha (162,8 milhões); estimulantes-tipoanfetaminas (metanfetaminas, anfetaminas e ecstasy - 34,3 milhões); opiáceos (14,9 milhões) e cocaína (14,1 milhões). Observou-se que o uso de estimulantes-tipoanfetamina é o que mais aumentou e que o uso do ecstasy disseminou-se para a Ásia e para as Américas.

Segundo outro relatório da mesma organização, mais de 130 países, entre desenvolvidos e em desenvolvimento, relataram problemas de abuso de drogas em sua população. O abuso de drogas é, há mais de 10 anos, um fenômeno global (WORLD DRUG REPORT, 2000).

A maconha continua a ser a droga mais consumida em termos globais, sendo usada em praticamente todos os países do mundo. A cocaína vem apresentando declínio de consumo nos EUA, mas aumento em vários países da América do Sul e 
Central, sul e oeste da África e Europa. A heroína tem crescido principalmente nos países do leste europeu e Ásia Central (WORLD DRUG REPORT, 2000).

Em outro relatório emitido pela ONU, o Global Illict Drug Trends (2002), são apresentados dados semelhantes aos de 2000, mas com algumas diferenças importantes. Observou-se que o consumo das anfetaminas-tipoestimulante continua a crescer, sendo o ecstasy uma das drogas deste tipo mais consumida, tendo se espalhado dos países do oeste europeu para as Américas.

As diferenças das formas e tipos de drogas consumidas por homens e mulheres continuam a ser importantes. Os homens ainda mantêm a posição de principais consumidores de drogas ilícitas. Apesar desta diferença, a cada ano que passa, as mulheres têm se aproximado dos homens em termos das prevalências dos consumos, principalmente nos países desenvolvidos. Nos países ditos mais tradicionais, como os asiáticos e mulçumanos, e em desenvolvimento, notadamente os da América Latina, as diferenças por gênero ainda são muito expressivas. (GLOBAL ILLICIT DRUG TRENDS, 2002). Outra diferença marcada ainda pelo gênero é o tipo de droga preferencialmente consumida por homens e mulheres. As mulheres continuam a consumir, em maior escala, os medicamentos como: tranqüilizantes, sedativos, analgésicos e anfetaminas. Os homens consomem mais heroína, crack, cocaína e metanfetaminas. (GLOBAL ILLICIT DRUG TRENDS, 2002).

Outro fator apontado como tendo associação com um maior consumo de substâncias psicoativas é a situação de emprego. Entre pessoas desempregadas, a prevalência de uso de drogas é maior do que entre pessoas empregadas. Esta associação parece estar presente na maior parte dos países do mundo, no entanto, são nos países desenvolvidos onde se encontrou resultado mais expressivo. Por exemplo, nos EUA, o risco de consumo de drogas entre desempregados é $40 \%$ 
maior do que entre os empregados. O relatório não esclarece, no entanto, quais os critérios de classificação de emprego/desemprego foram utilizados na pesquisa, o que dificulta saber como esta variável poderia ser medida e nosso país e se estas conclusões são válidas para nossa. Queiroz (2000), analisando os dados do estudo realizado em 1996 entre estudantes da Universidade de São Paulo (ANDRADE, 1997), constatou que estar trabalhando, mostrou associação positiva com um maior consumo de drogas ilícitas. Exatamente o contrário do apontado naquele relatório. Fato que indica a variabilidade e complexidade do fenômeno estudado.

Quanto à idade, em praticamente todos os países do mundo, a prevalência de drogas ilícitas é maior entre pessoas mais jovens do que entre as mais velhas. $O$ maior consumo concentra-se na faixa que vai dos 18 aos 25 anos. A droga ilícita de maior prevalência no mundo, entre os jovens, é a maconha. No entanto, tem-se observado um aumento no consumo de múltiplas drogas entre jovens na faixa de 1516 anos. (GLOBAL ILLICIT DRUG TRENDS, 2002). Nesta faixa etária, nos países do leste europeu, como Romênia, Lituânia, Rússia e Croácia, a heroína é a droga mais popular. Outra droga que tem sido utilizada em grande escala por jovens dessa faixa etária é a anfetamina-tipo-estimulante, principalmente nos países do oeste da Europa, EUA e Austrália. (GLOBAL ILLICIT DRUG TRENDS, 2002).

Em termos das tendências mundiais, tem-se observado que apesar de algumas drogas apresentarem declínio no seu consumo em alguns países, no geral, mais países têm apresentado um aumento de consumo de drogas do que diminuição. (GLOBAL ILLICIT DRUG TRENDS, 2002). No ano de 2000, 64 países relataram aumento de consumo de maconha, enquanto que 11 declararam diminuição. A única substância em que este quadro se inverte, ou seja, mais países apresentaram diminuição do que aumento foi a morfina. As outras formas de opiáceos, que não heroína, morfina e ópio, apresentaram um quadro de equilíbrio, 9 
países apresentaram aumento e diminuição de consumo. (GLOBAL ILLICIT DRUG TRENDS, 2002). 


\subsection{O uso de drogas no Brasil}

Comparado ao padrão mundial, o Brasil apresenta prevalências importantes para diversos tipos de drogas. É importante, no entanto, atentar para algumas especificidades.

O álcool é a droga mais utilizada pelos brasileiros. Cerca de 68,7 \% da população fez uso pelo menos uma vez na vida desta substância. A variável sexo continua a marcar diferenças de consumo destas substâncias. Os homens bebem mais do que as mulheres, $77,3 \%$ contra $60,6 \%$. O tabaco é a segunda droga mais consumida. $41,1 \%$ já fizeram uso pelo menos uma vez na vida. (CARLINI et al., 2002), ou seja, as substâncias legais são as mais intensamente consumidas.

Sobre as drogas ilegais, seguindo a tendência mundial, a maconha é a principal droga ilegal utilizada no Brasil. Segundo o CARLINI et al. (2002), em seu levantamento domiciliar, cerca de $6,9 \%$ dos entrevistados fez uso pelo menos uma vez na vida de maconha. Dado que é semelhante aos 6,8\%, estimado pelo World Drug Report (2000), para o uso nos últimos 12 meses de maconha dentro da população Brasileira. Como as estimativas da ONU (Organização das Nações Unidas) foram feitas a partir de pesquisas com amostras parciais de população brasileira, pode-se esperar uma revisão destes dados para os próximos relatórios, provavelmente para menos. A segunda droga ilegal mais consumida são os solventes, com 5,8\% de prevalência dentro da população (CARLINI et al., 2002). Segundo estes pesquisadores o uso na vida de orexígenos (remédios para abrir o apetite) foi feito por 4,3\% da população, e o uso de benzodiazepínicos sem indicação ou receita médica, por 3.3\% (CARLINI et al., 2002). Os estimulantes, principalmente como parte dos medicamentos anorexígenos, foi utilizado por $1,5 \%$ dos entrevistados (CARLINI et al., 2002). Segundo a UNODC (Escritório das Nações Unidas para o Controle de Drogas e Crimes), o uso de anfetaminas nos últimos 12 meses foi de 
0,7\% (GLOBAL ILLICIT DRUG TRENDS, 2002). O ecstasy, que aparentemente não foi investigado na pesquisa de CARLINI et al. (2002) e, no relatório da UNODC, também aparece como um dado não disponível para a população brasileira, tem sido mundialmente considerada uma droga de abuso, principalmente entre os mais jovens (GLOBAL ILLICIT DRUG TRENDS, 2002).

O uso na vida de cocaína tem a prevalência de 2,3\% entre os entrevistados (CARLINI et al., 2002). Segundo dados da UNDCP, a prevalência de uso desta droga nos últimos 12 meses no Brasil foi de 0,8\% na última década (GLOBAL ILLICIT DRUG TRENDS, 2002).

Pode-se concluir, por estes dados, que o Brasil apresenta um consumo de drogas menor que a maior parte dos países do mundo, principalmente os da América do Norte e da Europa. No entanto, dentro da América do Sul, o Brasil apresenta um dos maiores índices da região para diversas drogas como maconha e anfetaminas (GLOBAL ILLICIT DRUG TRENDS, 2002).

Outras fontes importantes de dados sobre o tema são os levantamentos com populações de estudantes de primeiro e segundo graus. O estudo de Galduróz et al. (1997), demonstrou tendências de aumento de consumo de algumas drogas nos últimos 10 anos entre os estudantes brasileiros em 10 capitais. Apresentaram aumento de uso na vida: maconha, cocaína, tabaco, anfetamínicos, solventes, ansiolíticos e Álcool - as três primeiras drogas da lista apresentaram aumento de uso na cidade de São Paulo. Aumento de uso freqüente: maconha, nas 10 capitais; cocaína, em 6 capitais (Belém, Belo horizonte, Brasília, Porto Alegre, Salvador e São Paulo) e álcool, em 6 capitais (Brasília, Curitiba, Fortaleza, Porto Alegre, Rio de Janeiro e São Paulo). Apresentaram aumento de uso pesado: maconha, nas 10 capitais e álcool, em 8 capitais (exceto Belo Horizonte e Salvador). 
Podemos observar significativamente que, para a cidade de São Paulo, foram encontrados aumento do consumo de álcool, tabaco, cocaína e maconha entre os estudantes de primeiro e segundo graus de escolas públicas.

\subsection{Estudos epidemiológicos transversais sobre o uso de drogas entre estudantes universitários.}

Estudos epidemiológicos transversais, como é o caso desta pesquisa, possibilitam a elaboração de hipóteses sobre os fatores que expõem ou protegem os indivíduos de determinada característica, por exemplo, ao uso de drogas (GRISSO, 1993; KELSEY et al. 1996). Levantamentos epidemiológicos transversais são especialmente úteis para estabelecer a prevalência e identificar fatores de risco para determinadas doenças ou comportamentos de interesse (KELSEY et al., 1996). O padrão do uso de drogas e seus fatores associados podem ser identificados através deste método (KELSEY et al., 1996), que, se repetido periodicamente, pode fornecer dados sobre como as variáveis investigadas se comportam ao longo do tempo e se é possível identificar alguma tendência, podendo vir a se constituir num estudo seriado (GRISSO, 1993, BAUMAN, 1999). As limitações principais destes tipos de estudo referem-se à possibilidade de estabelecer relações temporais entre estas duas categorias de variáveis e, portanto, suas causalidades. Quando se pretende estabelecer tal relação deve-se recorrer aos estudos de coorte e prospectivos (GORDIS, 2000). Através da geração de hipóteses mais fortes sobre os fatores de risco associados, será possível compreender melhor este fenômeno, de modo a subsidiar outros tipos de pesquisa que aprofundem a investiguem as hipóteses levantadas e orientem as ações preventivas que vem sendo desenvolvidas com esta população. 
Quando se quer monitorar a evolução do uso de drogas, ou seja, como este comportamento está variando ao longo do tempo, uma possível resposta pode ser obtida através de estudos transversais periódicos com esta mesma população ou população semelhante. Este tipo de metodologia tem sido tradicionalmente utilizado e tem demonstrado confiabilidade em seus resultados comparando com os resultados de estudos de coorte e prospectivos (FÁVERO, 1984).

As pesquisas realizadas com alunos universitários nos últimos quinze anos (ZANINI et al., 1977-78; MURAD, 1979; GORESTEIN, 1983; SZEGO et al., 1985; PLOTNIK, 1986; BRENES, 1986; CARVALHO, 1986; BUCHER e TOTUGUI, 1988; BOSKOWITZ et al., 1990; MAGALHÃES et al., 1991; ARAP et al., 1992; MESQUITA et al., 1992) possuem diferentes metodologias, com amostragens distintas, dificultando estudos comparativos. No entanto, a maioria dos estudos concorda sobre dois pontos: que o uso de álcool e drogas por estudantes universitários é maior do que a população em geral e que entre estudantes de nível fundamental e intermediário; e que este consumo é, na maioria das vezes, recreativo.

Poucos estudos foram feitos no Brasil tentando caracterizar os estudantes em termos dos diagnósticos de abuso ou dependência. Ou seja, o fato de não se ter investigado estas questões pode, na verdade, dar a impressão de que este tipo de comportamento é raramente observado entre os estudantes universitários brasileiros. Tomando por base estudos realizados com estudantes de universidades americanas, pode-se concluir, no entanto, que a realidade deve ser outra. Wechsler et al. (WECHSLER et al. 1999) calculou a prevalência de uso excessivo de álcool (cinco ou mais doses em uma mesma situação de uso nas últimas duas semanas para homens e quatro doses para mulheres) em $44 \%$ dos estudantes de uma amostra nacional de estudantes universitários americanos. Knight et al. (kNIGHT et al. 2002) calculou para a mesma amostra de estudantes que 31\% cumpriam critério para diagnóstico de abuso de álcool segundo o DSM IV e 6\% para dependência nos últimos 12 meses.

Apesar das diferenças culturais entre Brasil e Estados Unidos da América, algumas semelhanças podem ser observadas quanto ao uso de drogas por estudantes universitários. Como no Brasil, as prevalências para a maioria das drogas tendem a ser maiores do que para a população em geral da mesma faixa etária e estudantes de nível secundário (O’MALLEY e JOHNSTON, 2002). Vários estudos enfatizam a importância do ambiente universitário e fatores psicossociais para a compreensão deste fenômeno (O’MALLEY e JOHNSTON, 2002; PRENDERGAST, 1994), das atitudes quanto ao uso de drogas e percepção de seu risco (BACHMAN, JOHNSTON e O'MALLEY, 1998), do estilo de vida dos estudantes (POPE, IONESCU-PIOGGIA e POPE, 2001), dos relacionamentos com os amigos (READ et al 2002; BORSARI e CAREY, 2001) e familiares (SZALAY, INN e DOHERTY, 1996), etc. 
Outra categoria de dados importantíssima para a compreensão deste fenômeno e para a implementação de ações de saúde com esta população, mas que não dispomos em nosso país, é a tendência do uso de drogas. Tomando por base pesquisas norte-americanas, aparentemente o que se observa ao longo das três últimas décadas, em que os estudos epidemiológicos com esta população tornaram-se mais sistemáticos e padronizados, são variações para mais ou para menos dependendo da década observada. A década de 70 foi a que o consumo atingiu seus maiores índices, caiu na década de 80 e voltou a subir um pouco no início dos anos 90, voltando a cair no final desta última década e no início dos anos 2000 (BACHMAN, JOHNSTON e O'MALLEY, 1998; POPE, IONESCU-PIOGGIA e POPE, 2001).

A USP possui um serviço especializado para o tratamento da dependência de drogas, o PRODUSP (Programa de prevenção e tratamento do uso de drogas na USP). A análise dos dados relativos a procura deste serviço, revela que em 6 anos de funcionamento $o$ serviço foi procurado por 34 alunos para realizar tratamento para a dependência de alguma substância psicoativa. Mesmo sendo um número que não expressa a realidade da dependência de drogas entre os alunos, pois pode ter havido a procura por alguns alunos de serviços fora da universidade. Chama a atenção a diferença entre as relativamente altas prevalências do consumo de drogas encontradas por Andrade et al. (1997), e a procura por tratamento. Além da idade, é possível imaginar que outros fatores ajudem a explicar este fenômeno configurando um contexto sócio-cultural que de alguma maneira protege os alunos dos danos da dependência.

No entanto, outros danos importantes acontecem decorrentes do uso excessivo de drogas pelos estudantes universitários. Kerr-Correa et al. (2001), encontrou associação positiva entre a freqüência de consumo de álcool e a queda do desempenho acadêmico (p. 34). Yu (2001), concluiu em seu estudo que o uso do álcool se dá em situações de interação social e que quanto mais alcoolizados, mais risco os estudantes apresentam em sofrer algum dano decorrente deste uso excessivo. Portanto, parece importante investir em programas de prevenção que atuem nas variadas formas de uso de drogas, a fim de reduzir a experimentação, prevenir o abuso ou dependência, e reduzir os danos decorrentes de qualquer forma de consumo, mas principalmente o excessivo.

Um estudo recentemente concluído que auxilia a vislumbrar um quadro mais atual do uso de drogas entre estudantes universitários fora do município e do estado 
de São Paulo, é a pesquisa realizada por Mourão (2001). Neste estudo o pesquisador realizou um levantamento do uso de drogas com estudantes de graduação de quatro faculdades da Universidade Federal de Minas Gerais: Belas Artes, Biblioteconomia, Odontologia e Veterinária. Foram investigados 641 alunos, o que permitiu ao autor concluir que "o consumo de drogas entre os alunos das quatro faculdades da UFMG é extremamente preocupante. As prevalências de álcool, tabaco, maconha e cocaína foram muito altas em toda a amostra". (MOURÃO, 2001).

Os dados encontrados por Mourão (2001), são muito semelhantes aos encontrados por Andrade et al. (1997) e Kerr-Correa et al. (2001), e reforçam o grupo de pesquisas que apontam uma prevalência relativamente alta de diversas drogas entre a população universitária, com relação principalmente a população em Geral (CARLINI et al., 2002, VEGA et al, 2002).

\subsection{Fatores de risco para o uso de drogas entre estudantes universitários}

De acordo com Swadi (SWADI, 1999) "fatores de risco na área de saúde mental são características, variáveis ou eventos, que se presentes em um indivíduo, fazem com que este tenha uma probabilidade maior, se comparado com alguém selecionado da população em geral, de desenvolver algum tipo de distúrbio psicológico ou psiquiátrico". Com relação ao abuso de drogas, vários estudos têm buscado determinar fatores relacionados ao início, manutenção e dependência de substâncias psicoativas. Paralelamente, diferentes teorias têm sido elaboradas com o objetivo de dar um sentido mais abrangente e explicativo aos diferentes grupos de fatores encontrados. Swadi (SWADI, 1999) lista nove categorias de fatores que têm 
mostrado associação com o aumento do risco para o uso de drogas: Eles são: fatores constitucionais (características de personalidade, comportamento anti-social e agressivo, psicopatologia, distúrbios de conduta, distúrbios de humor, uso anterior de drogas e fatores genéticos); fatores ambientais (grupo de amigos, uso de drogas pelos pais ou membros da família e relacionamentos afetivos); e eventos experienciados na vida.

Kilpatrick et al. (KILPATRICK, 2000) investigaram fatores de risco para abuso de drogas e/ou dependência em uma amostra de 4.023 adolescentes entre 12 e 17 anos. Os autores encontraram que "adolescentes que sofreram agressão física ou sexual, que testemunharam violência ou tiveram membros da família com problemas de uso de álcool ou alguma droga ilegal, apresentavam maior risco para uso corrente, abuso e dependência de drogas". Outros fatores que apresentaram associação foram: "Distúrbio de stress pós-traumático" que aumenta o risco para o uso de maconha e o abuso e dependência de outras drogas como cocaína e heroína; raça: "Adolescentes afro-americanos, ao contrário de centro e sul americanos ou indígenas, apresentaram $1 / 3$ do risco dos adolescentes brancos para abuso ou dependência de drogas" após o controle das variáveis "ter sido vítima de violência física ou sexual ou testemunhado violência” (KILPATRICK, 2000).

Pesquisando questões semelhantes, Bates e Labouvie (BATES e LABOUVIE, 1997) investigaram em qual medida fatores de risco que estavam presentes em adolescentes aos 18 anos poderiam prever o abuso de álcool e outras drogas anos mais tarde, quando estes adolescentes atingissem a idade adulta. Em uma amostra de 823 adolescentes do estado de New Jersey, EUA, os autores determinaram seis prováveis "preditores" do abuso de álcool e outras drogas da adolescência para a vida adulta: "características de personalidade que predispõem ao uso de drogas (desinibição e estrutura 
de pensamento); predisposição comportamental, comportamento desviante, características ambientais, amigos com comportamento desviante e ter passado por eventos stressantes na vida". Apesar do modelo se útil para descrever algumas características associadas com diferentes possíveis trajetórias de vida entre os adolescentes, os autores concluem: "no entanto, quando as diferenças que concorrem para o uso de álcool e outras drogas na adolescência são controladas, não existe uma expressiva relação entre o uso de drogas na adolescência e o uso de drogas na vida adulta e as conseqüências adversas desse uso entre 28 e 31 anos" (BATES e LABOUVIE, 1997). Com estas constatações os autores enfatizam a importância das ações preventivas para esta faixa etária. Ao promover mudanças ambientais, comportamentais e cognitivas programas de prevenção podem ser efetivos em reduzir o risco do agravamento do uso de drogas por adolescentes e mesmo extingui-lo.

Entre estudantes universitários alguns estudos mostraram algumas características que aumentam o risco para o uso de álcool e drogas ilegais. Schall et al. (SCHALL, KEMENY e MALTZMAN, 1992), estudando 731 estudantes de graduação matriculados em um curso introdutório de psicologia, encontraram que gênero, raça e diferenças de grupos sociais eram fatores relacionados a maior prevalência do uso de álcool. Para estudantes do sexo masculino, latinos ou brancos, viver longe da família mostrou ser o mais forte preditor para uso de álcool. Outras variáveis importantes eram: "expectativas positivas quanto aos efeitos do álcool; usar álcool para aumentar auto-estima, autoconfiança e esquecer os problemas; atitude favorável ao consumo excessivo de álcool e participação em atividades sociais envolvendo consumo excessivo de álcool (festas onde somente é servido álcool para beber e gostar de sair com os amigos para 
beber)" (SCHALL, KEMENY e MALTZMAN, 1992). A limitação deste estudo é que suas conclusões não podem ser generalizadas para outros estudantes. No entanto, os autores determinaram variáveis extremamente importantes para 0 objetivo de reduzir 0 consumo de álcool entre estudantes universitários.

No Brasil, por sua abrangência amostral, destacam-se duas pesquisas realizadas com estudantes universitários que investigaram os fatores de risco para o uso de drogas nesta população. Nas pesquisas realizadas por KerrCorrêa et al. (KERR-CORRÊA et al., 2001) e Queiroz (QUEIROZ, 2000) as seguintes variáveis estavam associadas com um risco maior de uso de drogas: características pessoais; opinião favorável com relação a alguém usar drogas; fazer uso de alguma droga e características dos amigos e familiares. Estes estudos são relevantes, pois ajudam a visualizar como o uso de drogas se distribui nesta população e quais indivíduos e grupos estão mais vulneráveis. A abordagem teórica que orientou a interpretação dos resultados enfatizou a quantidade de fatores de risco presente como preditor do nível de vulnerabilidade. Nossa hipótese é que as normas e os valores compartilhados entre as redes sociais (BERKMAN e GLASS, 2000) estabelecidas pelos estudantes são importantes grupos de fatores para prever e compreender o nível e o perfil do uso de álcool e outras drogas entre estudantes universitários e constituem importantes alvos de programas preventivos.

\subsection{0 uso de drogas entre estudantes da USP}

O GREA com o apoio financeiro da FAPESP e do estabelecimento de outras parcerias tem contribuído para tornar mais clara a visão da questão do uso de drogas 
entre estudantes universitários da cidade e do estado de São Paulo (ANDRADE et al., 1995, 1996, 1997). Os resultados obtidos através da pesquisa "Álcool e Drogas: Pesquisa sobre Atitudes e Uso em Alunos da Universidade de São Paulo - Campus São Paulo" (1995-96), indicam prevalência de uso de drogas ilícitas de 38,1\% na vida, 26,3\% últimos 12 meses e 18,9\% nos últimos 30 dias (ANDRADE, 1997), resultados superiores aos encontrados por Galduroz et al. (1997), com estudantes de $1^{\circ}$ e $2^{\circ}$ graus e por Magalhães et al. (1991), com estudantes universitários da cidade de São Paulo. Outro dado relevante demonstrado por Andrade et al. (1997), provém dos diversos subgrupos em que a amostra de estudantes da USP foi dividida (áreas de estudo; sexo; situação de moradia; período de curso; e ano de ingresso), e que apresentavam padrões diferentes de consumo de drogas. Por exemplo, o fato do consumo de drogas ilícitas ser maior entre os alunos da área de humanas e os que moram sem a família.

Verifica-se também que a maconha é a droga de maior aprovação para uso regular e experimental dentro da Universidade de São Paulo (QUEIROZ, 2000), o que demonstrou ser um fator de risco para o uso de outras drogas. Estudantes com opinião positiva quanto ao uso experimental de maconha apresentam prevalência 2,7 vezes superior de ter feito uso de algum tipo de droga ilícita no último ano, e entre os que são de opinião favorável ao uso regular de maconha, esta prevalência é 3,2 vezes superior do que a encontrada entre aqueles que possuem opinião desfavorável. 


\section{OBJETIVOS E HIPÓTESES}

\subsection{Objetivo geral}

Avaliar o padrão de uso de álcool e outras drogas pelos alunos de graduação da USP, no Campus São Paulo.

\subsection{Objetivos específicos}

3.2.1 Comparar o padrão de uso de álcool e outras drogas com o levantamento realizado em 1996.

3.2.2 Comparar as atitudes frente ao uso de álcool e outras drogas com o levantamento realizado em 1996.

3.2.3 Identificar os grupos específicos mais expostos ao problema e as drogas mais utilizadas.

3.2.4 Avaliar a relação entre características individuais, sócio-econômicas e ambientais e o consumo corrente (últimos 30 dias) de álcool e recente (últimos 12 meses) de drogas ilegais. 


\subsection{Hipóteses básicas}

Foram adotadas como hipóteses nulas $\left(\mathrm{H}_{0}\right)$ que as atitudes e as prevalências do uso das diversas drogas entre os alunos não mudaram entre as duas pesquisas e não são diferentes entre os alunos das diversas áreas de ensino, sexo e período de curso. As hipóteses alternativas $\left(H_{1}\right)$ são que existem variáveis que apresentem prevalências diferentes das esperadas. Caso as hipóteses nulas sejam refutadas, será possível identificar as variáveis relacionadas a estas diferenças e que estão influenciando os usos diferenciados de drogas por parcelas desta população. 


\section{CASUÍSTICA E MÉTODOS}

\subsection{Aspectos éticos}

O projeto foi submetido à Comissão de Ética do Departamento de Psiquiatria da Faculdade de Medicina da Universidade de São Paulo e recebeu parecer positivo para ser realizado (anexo A). A participação dos alunos no projeto foi voluntária e se deu após esclarecimento de seus objetivos. Os alunos que concordaram em participar do projeto assinaram um termo de consentimento pós-informação, conforme modelo em anexo (anexo B). O nome dos alunos foi mantido em sigilo de modo a preservar o anonimato das informações e garantir a liberdade de expressão das opiniões.

\subsection{Plano de amostragem}

O plano de amostragem foi elaborado de modo semelhante ao da primeira pesquisa realizada em 1996. A população de estudo constitui-se dos alunos matriculados em 2000 e 2001 em algum curso de graduação da Universidade de São Paulo, que, segundo o Anuário Estatístico USP (1999), o mais atualizado até aquele momento, totalizava 32.894 alunos. O objetivo foi estimar as proporções desses alunos que fizeram uso de drogas em três níveis: na vida, nos últimos 12 meses e nos últimos 30 dias.

Estimou-se as proporções separadamente em cada "Área de Estudo", as três em que se dividem os cursos da USP: Ciências Humanas, Exatas e Biológicas. Cada área de estudo constituiu-se num domínio de estudo. Em cada uma delas, o estimador a ser utilizado foi: 


$$
P_{h}=\frac{}{n_{h}}
$$

sendo $y_{h i}=1$ i-ésimo aluno da área $\mathrm{h}$ tiver usado a droga em estudo

$\mathrm{y}_{\mathrm{hi}}=0$ caso contrário

$\mathrm{n}_{\mathrm{h}}$ é o número de alunos da área $\mathrm{h}$

Para o conjunto das áreas, o estimador passa a ser

$\mathrm{p}=\sum \mathrm{W}_{\mathrm{h}} \cdot \mathrm{p}_{\mathrm{h}}$

$$
\mathrm{W}_{\mathrm{h}}=\frac{\mathrm{N}_{\mathrm{h}}}{\mathrm{N}}
$$

Onde $\mathrm{N}_{\mathrm{h}}$ 'e o número de alunos matriculados na área $\mathrm{h}$

N é o número total de alunos

\subsection{Cálculo do tamanho da amostra}

Para determinar o número de alunos a serem entrevistados em cada área, fixou-se que a diferença absoluta entre uma particular proporção obtida pela amostra e o seu valor na população deverá estar dentro do intervalo de confiança de $95 \%$ e uma margem de erro de 5\%. Optou-se por considerar, para fins de cálculo do tamanho da amostra, que a proporção estimada equivale a $40 \%$, pois o primeiro estudo determinou esta proporção como a encontrada na população de estudo (uso de drogas ilícitas na vida, total: 38,1\%, IC [35.3; 41,0] (ANDRADE et al., 1997).

O número inicial de alunos a serem sorteados em cada uma das áreas é dado por: 


$$
\mathrm{n}_{0}=\frac{P(1-p)}{(d / z)^{2}}
$$

onde p é a proporção de alunos que fazem uso de droga em estudo

d é a diferença máxima aceitável entre a proporção obtida na amostra e a populacional

z é o valor correspondente ao nível de significância de 5\% na distribuição Normal reduzida

Com os valores já definidos

$$
\mathrm{No}=\frac{0,4^{\star} 0,6}{(0,05 / 1,96)^{2}}=369
$$

Uma vez que se esperava obter em cada área, um número de entrevistas que permitisse conhecer as estimativas para grupos de alunos segundo sexo, período e ano de ingresso, o tamanho da amostra acima determinado foi dividido por 0,37 , que correspondia ao menor percentual de alunos segundo algum desses grupos.

$\mathrm{n}=369 / 0,37=997$

Para compensar possíveis perdas de unidades sorteadas, pelo não comparecimento do aluno para responder ao questionário ou pela necessidade de anulação de questões nele contidas, foi sorteado um número maior de alunos. Admitindo-se que as perdas seriam de $20 \%$, esse número foi transformado para 1197.

Considerando as três áreas, o número total de alunos que foram sorteados foi 3590. E a serem entrevistados, 2.872 (valor correspondente a $80 \%$ da amostra). 


\subsection{Realização do sorteio da amostra}

A amostra utilizada foi estratificada por área (Humanas, Exatas e Biológicas), com partilha igual, sendo a fração de amostragem dada por

$$
f_{h}=\frac{n_{h}}{N_{h}}
$$

Onde $\quad n_{h}$ é o número de alunos amostrados na área $h$

$\mathrm{N}_{\mathrm{h}}$ é o número de alunos matriculados na área $\mathrm{h}$

Os alunos foram selecionados por sorteio sistemático, tendo como intervalos de amostragens os valores 15,$1095 ; 5,2648 ; 7,1061$ nas áreas de Humanas, Biológicas e Exatas, respectivamente. Este sorteio foi realizado pelo setor de informática da Pró-Reitoria de Graduação da USP. Através de carta, foram passadas as informações de como deveria ser feito o sorteio e emitida a listagem de alunos sorteados.

$\mathrm{Na}$ tabela abaixo, estão totalizados os alunos distribuídos por área e unidade em função da listagem recebida da Pró-Reitoria de Graduação. O total de alunos sorteados foi de 3393, menor do que o previsto no Plano de Amostragem descrito acima. Esta diferença em relação ao total inicialmente calculado deveu-se a diferenças entre os totais de alunos matriculados no ano de 1999, utilizado para os cálculos iniciais, e o total de alunos matriculados no final de 2000, utilizado para o sorteio da amostra. Os principais motivos desta perda amostral foram o trancamento de matrícula e abandono do curso por parte dos alunos.

\section{Tabela 1 - Distribuição dos alunos sorteados por áreas e unidades dos cursos de graduação da USP.}




\begin{tabular}{llr}
\hline Área & Unidade & Sorteados \\
\hline Humanas & ECA & 95 \\
& FAU & 61 \\
& FD & 160 \\
& FEA & 235 \\
& FE & 38 \\
& FFLCH & 586 \\
\hline Exatas & Subtotal & 1175 \\
& EP & 577 \\
& IAG & 27 \\
& IF & 205 \\
& IGC & 43 \\
& IME & 187 \\
& IQ & 75 \\
\hline Biológicas & Subtotal & 1114 \\
& EEFE & 125 \\
& EE & 79 \\
& FCF & 153 \\
& FM & 252 \\
& FMVZ & 68 \\
& FO & 131 \\
& FSP & 41 \\
& IB & 159 \\
& IP & 96 \\
\hline Subtotal & 1104 \\
\hline Total & 3393 \\
\hline
\end{tabular}




\subsection{Método de Coleta de Dados}

\subsubsection{Cartas para as unidades da USP}

No dia 29 de novembro de 2000, foram enviadas cartas para todas as unidades da USP, informando sobre o início da coleta de dados da pesquisa e solicitando aos diretores de unidade autorização para a realização da mesma durante o período de matrículas. Entre os dias 4 e 8 de dezembro, foram visitadas as 13 unidades onde a coleta de dados efetivamente teria início. Dessa forma, confirmouse, junto aos Assistentes Acadêmicos e responsáveis pela Seções de Alunos, a autorização para o início da pesquisa e acertados detalhes do desenvolvimento desta atividade. Todas as unidades mostraram-se receptivas e concordaram em participar da pesquisa e colaboraram conosco fornecendo os horários corretos de matrícula e disponibilizando cadeiras e mesas para a realização da coleta.

\subsubsection{Recrutamento e treinamento dos auxiliares de pesquisa}

Para a realização da aplicação dos questionários, foram recrutados e treinados alunos de graduação da própria USP. A coleta de dados foi realizada por alunos da própria USP. É possível que está escolha dos aplicadores tenha facilitado a concordância dos sujeitos em participar da pesquisa, pois estes se apresentaram como alunos e pesquisadores, dirimindo algumas desconfianças inerentes a este tipo de pesquisa, onde há o relato de um comportamento ilícito (uso de drogas ilícitas). 0 índice de recusas foi baixo, 3,09 \% (105 alunos), e o motivo mais alegado para não participar da pesquisa foi a falta de tempo e não a desconfiança com relação as intenções da pesquisa. O restante da perda da amostra se deu em função da impossibilidade de encontrar estes alunos nas salas de aula dentro do prazo da pesquisa. 
Com o objetivo de padronizar o tipo de abordagem e as informações dadas pelos pesquisadores aos sujeitos, foram realizados 2 treinamentos com 2 horas de duração cada um. O primeiro aconteceu no dia 4 de dezembro e o segundo, no dia 8 de dezembro. Nas fases seguintes de coleta de dados, novos alunos foram recrutados e treinados seguindo este mesmo modelo, descrito a seguir.

O treinamento teve início com os alunos respondendo ao questionário da pesquisa. Em seguida, foi aberta uma discussão sobre as dúvidas a respeito dos objetivos da pesquisa e a redação e compreensão das questões, metodologia de amostragem e sugestões. Foi dada a seguir uma explicação de como seria feita a abordagem e aplicação: apresentação do material da pesquisa, o uso da listagem; apresentação e discussão do termo de consentimento; como se apresentar e explicar a pesquisa.

Por fim, houve dramatizações de abordagens com os alunos para que os mesmos tivessem a experiência da situação de abordagem e explicação da pesquisa, tirando dúvidas e treinando uma abordagem padronizada.

\subsubsection{Material para a coleta de dados}

Para cada unidade que participou da pesquisa, foram montadas duas urnas identificadas com o nome da unidade e as especificações, "questionários" ou "termos de consentimento". Cada aplicador possuía também uma pasta com os questionários e termos de consentimento na quantidade necessária para aquela unidade, a listagem de alunos sorteados, duas canetas de reserva e o crachá de identificação do aplicador. Foi elaborado um texto explicativo retomando questões do treinamento como: objetivos da pesquisa, forma de abordagem, metodologia de composição da amostra. 


\subsubsection{Confecção dos questionários, termos de consentimento e cartões do PRODUSP.}

O questionário aplicado nos alunos da USP (anexo C) foi basicamente o mesmo utilizado na pesquisa de 1996. Algumas alterações foram realizadas a fim de atualizá-lo, por exemplo, incluindo substâncias psicoativas que em 1996 não apresentavam uso expressivo, como ecstasy, ice etc, bem como retirando questões elaboradas especificamente para aquele primeiro levantamento.

Foram confeccionados 3000 questionários e termos de consentimento na gráfica que apresentou o menor orçamento e condições de preparar o material no tempo necessário.

Em função dos treinamentos e das reuniões para planejamento da pesquisa, foi decidido que os alunos que responderam o questionário receberam um cartão com os telefones do GREA, PRODUSP (Programa de Tratamento e Prevenção ao Abuso de Drogas da USP) e do Álcoolfone (Serviço de Orientação por telefone sobre assistência a complicações decorrentes do uso de álcool e outras drogas, para que qualquer dúvida ou necessidade de orientação e encaminhamento fosse atendida.

\subsubsection{Coleta de dados}

A pesquisa teve início durante o período da matrícula entre os dias 11 e 22 de dezembro de 2000 com 13 unidades. Deste modo, não participaram desta primeira fase a Escola Politécnica (EP) e a Faculdade de Economia e Administração (FEA), que optaram por matrícula via internet; e a Faculdade de Educação (FE), Faculdade de Filosofia, Letras e Ciências Humanas (FFLCH), Instituto de Psicologia (IP), Faculdade de Medicina (FM), Faculdade de Saúde Pública (FSP) e Faculdade de Direito (FD), que realizaram a matrícula antes do dia 4 de dezembro, caso da FM, 
FSP e FD, ou entre os dias 4 e 8 de dezembro. O Instituto de Biociências (IB) foi abordado apenas nos 2 últimos dias de matricula, dias 11 e 12, e, parcialmente, dada a dificuldade de selecionar aplicadores adequados para cobrir todos os períodos da matrícula. Desta forma, privilegiou-se outras unidades que teriam um comparecimento mais expressivo de alunos nestes dias.

Para a realização desta fase da coleta de dados, utilizamos a sala do GREA na Escola Politécnica que, por sua localização na Cidade Universitária e estrutura de espaço físico, armários, telefone, fax, computadores e proximidade dos locais de coleta, foi de grande utilidade para a agilização das atividades.

A coleta de dados teve início no dia 11 de dezembro de 2000 e se estendeu até o dia 21 de dezembro do mesmo ano. No dia 11/12, todos os auxiliares de pesquisa que estavam iniciando suas atividades foram levados pessoalmente pelos supervisores às unidades participantes e apresentados aos encarregados das Seções de Alunos. Este procedimento foi repetido todas as vezes em que um auxiliar comparecia pela primeira vez numa determinada unidade.

A coleta transcorreu como planejado, mas algumas alterações foram necessárias em função da percepção das necessidades específicas se apresentavam. Os principais problemas foram a falta de alguns auxiliares, que tiveram de ser substituídos por outros, e a colocação de mais de um auxiliar em algumas unidades em determinados horários, em função da enorme quantidade de alunos programados para comparecer à matrícula. Este foi o caso do Instituto de Física, onde trabalharam dois auxiliares em cada horário, e da Faculdade de Arquitetura e Urbanismo, onde também a abordagem foi feita por uma dupla de auxiliares.

A tabela abaixo apresenta o número de questionários aplicados nesta fase, por Unidades da USP e os totais em termos absolutos. 
Tabela 2 - Total de questionários sorteados e aplicados por unidade $e$ área.

\begin{tabular}{lrr}
\hline Unidades & Alunos sorteados & Questionários Aplicados \\
\hline FO & 131 & 74 \\
IME & 187 & 67 \\
FAU & 61 & 23 \\
IF & 205 & 75 \\
FCF & 153 & 38 \\
EEFE & 124 & 34 \\
EE & 78 & 19 \\
FMVZ & 68 & 27 \\
IQ & 75 & 17 \\
IAG & 27 & 19 \\
IGC & 43 & 20 \\
IB & 159 & 1 \\
ECA & 95 & 95 \\
Total & 1406 & 513 \\
\hline
\end{tabular}

Com a liberação dos recursos pela FAPESP, em março de 2001, teve início a segunda fase da coleta de dados, que durou de abril a outubro deste mesmo ano. Nesta fase, a estratégia de abordagem dos alunos foi a seguinte: o auxiliar foi até a sala de aula onde o aluno estava matriculado e convidou-o a participar da pesquisa. Para isso, houve a colaboração das secretarias de alunos de cada uma das 21 unidades, que levantaram as disciplinas em que o aluno estava matriculado, a sala e horários de aula.

Este trabalho foi realizado pelos próprios auxiliares e acompanhado pelos supervisores de campo. Apesar de ter se mostrado a melhor estratégia para chegar aos alunos, o trabalho transcorreu lentamente em função das dificuldades para encontrar os alunos nos horários fornecidos pelas secretarias, por faltas, atrasos, mudanças de horário e sala. Isso exigiu uma ida muito mais freqüente do que o planejado às unidades e ficou patente a necessidade de acrescentar à remuneração dos pesquisadores o ressarcimento das despesas com o transporte, o que implicou uma alteração no plano inicial de pesquisa que previa a aplicação da verba de transporte para o ressarcimento de despesas com transporte dos entrevistados. 


\subsubsection{Problemas encontrados}

Alguns problemas ocorreram durante a coleta de dados. Em função do período de final de ano e dos aplicadores serem todos alunos da graduação da USP, muitos estavam também realizando suas provas finais. Este fato foi o principal fator responsável pelo alto número de auxiliares recrutados e treinados, pois muitos não possuíam disponibilidade para permanecer trabalhando por horários e dias seguidos.

A listagem fornecida pela Pró-Reitoria de Graduação não estava totalmente atualizada, contendo alunos que já não freqüentavam o curso e com seus telefones e endereços desatualizados.

Em função das dificuldades e lentidão do andamento da coleta de dados, foi alterada também a forma de remuneração dos auxiliares: passaram a receber por questionário aplicado, e não por hora de trabalho, como inicialmente previsto. Esta mudança permitiu ter um maior controle sobre a aplicação dos recursos financeiros.

\subsubsection{Reposição da amostra}

Ao final de agosto de 2001, foi feita uma reposição de 738 alunos. Este número correspondeu ao total de perdas amostrais em função do levantamento dos alunos matriculados, sala e horário. Constatou-se que diversos alunos que constavam da listagem inicial fornecida pela Pró-Reitoria de Graduação não constavam das listagens levantadas junto as secretarias de graduação das diversas unidades e haviam trancado matrícula, mudado de curso ou abandonado a universidade. Somente nas unidades em que esta diferença ultrapassou vinte por cento da amostra foi realizada a reposição. 
Tabela 3 - Porcentagem de perdas amostrais por unidade onde este total foi superior a $\mathbf{2 0} \%$ do total de alunos inicialmente sorteado.

\begin{tabular}{lrrr}
\hline & Sorteados & Total de perdas & \% de Perda \\
\hline FE & 38 & 15 & 39.47 \\
FD & 160 & 34 & 21.25 \\
EEFE & 125 & 50 & 40,00 \\
EE & 79 & 27 & 34.17 \\
FAU & 61 & 30 & 49.18 \\
IP & 96 & 45 & 46.85 \\
FFLCH & 586 & 216 & 36.86 \\
EP & 577 & 140 & 24.26 \\
IF & 205 & 60 & 29.26 \\
FCF & 153 & 40 & 26.14 \\
FM & 252 & 53 & 21.03 \\
FMVZ & 68 & 28 & 41.17 \\
\hline TOTAL & 2400 & 738 & \\
\hline
\end{tabular}

Esta reposição foi feita através de um novo sorteio, utilizando a mesma metodologia do primeiro e obtendo-se uma listagem com os 738 alunos com matrícula no segundo semestre de 2001.

\subsubsection{Visitas de supervisão de campo}

Durante todo o período de aplicação, pelo menos um supervisor permaneceu na USP para resolver qualquer intercorrência. Periodicamente, uma vez pela manhã, tarde e noite, um supervisor comparecia aos locais de aplicação para checar o andamento da pesquisa, repor materiais e recolher os questionários aplicados. Estas atividades do supervisor mostraram-se extremamente importantes e permitiram que a coleta transcorresse sem qualquer problema não solucionado imediatamente.

Nas fases seguintes, coube aos supervisores o acompanhamento diário do processo de coleta de dados através de reuniões com os aplicadores. 


\subsection{Método de análise de dados}

\subsubsection{Descrição da amostra e comparações entre as áreas, sexo, período e os anos de 1996 e 2001}

As análises foram realizadas durante a coleta de dados e ao final da pesquisa. No período da coleta de dados, o objetivo das análises foi o de acompanhar o desenvolvimento da coleta de dados e obter resultados preliminares que permitissem monitorar o processo. Ao final da pesquisa, foram realizadas análises estatísticas para comparar os resultados desta pesquisa aos resultados da pesquisa realizada em 1996 e também comparar as proporções de uso de drogas entre as três áreas de estudo, os sexos e os períodos. As comparações segundo sexo e período foram feitas através da construção de intervalos de confiança para as diferenças de prevalências nas

duas categorias (Diurno e Noturno, Masculino e Feminino). Para a comparação entre áreas, foram construídos intervalos de confiança simultâneos, controlando o nível de confiança como no Método de Bonferroni (NETER et al, 1996).

Para a comparação de período, o estimador de cada área em relação ao período é:

$\hat{p}_{h d}=\frac{\sum_{i=1}^{n_{h d}} y_{i}}{n_{h d}}$

$h=1,2,3 \quad$ (humanas,biológicas exatas respectivamente)

$n_{h d}=$ númerode alunos da área $\mathrm{h}$ e do períododiurnoque responderam ao questionáio sobrea droga em questão $\mathrm{y}_{\mathrm{i}}=1$ se o $\mathrm{i}$ - ésimoalunoda área h e períododiurnotiver usadoa droga em estudoe zerocasa contrário (análogo para o período noturno $\hat{p}_{h n}$ ) 
O estimador de cada período é:

$\hat{p}_{d}=\frac{\sum_{h=1}^{3} N_{h d} \hat{p}_{h d}}{N_{d}}$

$N_{h d}=$ número de alunos matriculados da área h e do período diurno

$N_{d}=$ número de alunos matriculados do periodo diurno

(análogo para o período noturno $\hat{p}_{n}$ )

A variância do estimador da prevalência em cada período foi aproximada por:

$\operatorname{Var}\left(\hat{p}_{d}\right) \cong \sum_{h=1}^{3}\left(\frac{N_{h d}}{N_{d}}\right)^{2} \operatorname{Var}\left(\hat{p}_{h d}\right)$

$\operatorname{Var}\left(\hat{p}_{h d}\right)=\frac{\left(N_{h d}-n_{h d}\right) \hat{p}_{h d}\left(1-\hat{p}_{h d}\right)}{N_{h d}\left(n_{h d}-1\right)} \quad$ para $\mathrm{h}=1,2,3$

(análoga para $\left.\operatorname{Var}\left(\hat{p}_{n}\right)\right)$

Para efetuar a comparação entre as prevalências

$\left(\hat{p}_{d}-\hat{p}_{n}\right) \pm 1,96 \sqrt{\operatorname{Var}\left(\hat{p}_{d}\right)+\operatorname{Var}\left(\hat{p}_{n}\right)}$

para $\alpha=5 \%$

Caso as prevalências nos períodos Noturno e Diurno sejam iguais, espera-se que o zero esteja contido no intervalo.

Por exemplo: para cocaína de uso na vida, o intervalo obtido foi ( -0,05622 ; 0,00555), concluindo assim que o consumo é maior entre os alunos do período Noturno, pois analisamos $\hat{p}_{d}-\hat{p}_{n}$.

Para a comparação de sexo foi feito processo análogo ao descrito no parágrafo anterior.

Para a comparação de áreas, como temos três áreas, fizemos a comparação duas a duas, utilizando a mesma idéia do Método de Bonferroni (NETER et al, 1996).

Estimador da prevalência em cada área: 
$\hat{p}_{h}=\frac{\sum_{i=1}^{n_{h}} y_{h i}}{n_{h}}$ para $\mathrm{h}=1,2,3$

$y_{h i}=1$ se o i - ésimo aluno da área h tiver usado a droga em estudo, e zero caso contrário

$n_{h}=$ número de alunos da área h que responderam ao questionário sobre a droga em estudo

Cálculo da variância

$\operatorname{Var}\left(\hat{p}_{h}\right)=\frac{\left(N_{h}-n_{h}\right) \hat{p}_{h}\left(1-\hat{p}_{h}\right)}{N_{h}\left(n_{h}-1\right)} \quad$ para $h=1,2,3$

$N_{h}=$ número de alunos matriculados da área $\mathrm{h}$

Comparação duas a duas

Para humanas(1) e biológicas(2): $\left(\hat{p}_{1}-\hat{p}_{2}\right) \pm 2,39 \sqrt{\operatorname{Var}\left(\hat{p}_{1}\right)+\operatorname{Var}\left(\hat{p}_{2}\right)}$

Para humanas(1) e exatas(3): $\left(\hat{p}_{1}-\hat{p}_{3}\right) \pm 2,39 \sqrt{\operatorname{Var}\left(\hat{p}_{1}\right)+\operatorname{Var}\left(\hat{p}_{3}\right)}$

Para biológicas(2) e exatas(3): $\left(\hat{p}_{2}-\hat{p}_{3}\right) \pm 2,39 \sqrt{\operatorname{Var}\left(\hat{p}_{2}\right)+\operatorname{Var}\left(\hat{p}_{3}\right)}$

O nível de confiança é controlado pelo número de intervalos que se queira construir:

para $\alpha=5 \%$,

$1-\frac{\alpha}{2 g}=0,9916 \quad$ sendo $\mathrm{g}=$ número de possíveis comparações, no caso são três

As conclusões são determinadas de maneira análoga às conclusões obtidas nas comparações de período e sexo.

Por exemplo, para o uso de álcool na vida entre as áreas Humanas e Biológicas $\hat{p}_{1}-\hat{p}_{2}$, o intervalo foi $(-0,07136 ;-0,01664)$, notando assim um consumo maior da droga entre os alunos da área de Biológicas.

\subsubsection{Procedimentos para a construção dos modelos de regressão logística}


Foram construídos dois modelos de regressão logística: uso corrente de álcool que foi definido como qualquer uso de álcool no último mês. Foi considerado como resposta, o fato de ter usado ou não; e uso recente de drogas ilegais, definido como qualquer uso de drogas ilegais no último ano, foi considerado como uso o fato de ter usado pelo menos uma das drogas ilegais e como não uso o fato de não ter usado nenhuma delas.

Primeiro foi realizada uma análise individual das seguintes variáveis versus a uso ou não: Perfil do Aluno (sexo, faixa etária, estado civil, condições de moradia (pais, cônjuge,etc.), ter religião, praticar religião e atividade remunerada); ambiente familiar (escolaridade do pai, escolaridade da mãe, renda familiar, pais vivem, problemas causadas pela bebida por algum familiar (sim/não), pai faz uso freqüente de álcool, mãe faz uso freqüente de álcool, irmão faz uso freqüente de álcool, pai faz uso freqüente de drogas, mãe faz uso freqüente de drogas e irmão faz uso freqüente de drogas); curso universitário (ano de ingresso, área, unidade, ano do curso e período); vida acadêmica (lugares que freqüenta na universidade, satisfação com a escolha profissional, pensou em abandonar o curso, ano em que pensou em abandonar o curso, deixa de fazer trabalhos acadêmicos, desempenho escolar, perspectivas de trabalho e financeiras após formatura, aprovação no último semestre e atividade quando falta às aulas); grupo de amigos (dificuldades em fazer novos amigos, sentir-se rejeitado pelos amigos, julgar-se facilmente influenciável pelos amigos, amigos fazem uso freqüente de álcool e amigos fazem uso freqüente de drogas); lazer (horas livres nos dias úteis, horas livres nos fins de semana, atividades nas horas livres e dedica às atividades tempo satisfatório); uso pessoal de drogas (usou álcool nos últimos 12 meses (aqui inverter para usou drogas nos últimos 12 meses para o modelo para uso corrente de álcool), usou tabaco no últimos 12 meses, experimentou drogas antes de entrar na universidade e envolveu-se em acidente de carro após uso de drogas e/ou álcool); atitudes relacionadas ao uso de 
drogas (o que pensa a respeito de uma pessoa experimentar álcool, o que pensa a respeito de uma pessoa experimentar maconha, o que pensa a respeito de uma pessoa experimentar cocaína, o que pensa a respeito de uma pessoa experimentar crack, o que pensa a respeito de uma pessoa experimentar tranqüilizantes, o que pensa a respeito de uma pessoa experimentar anfetaminas, o que pensa a respeito de uma pessoa experimentar inalantes, o que pensa a respeito de uma pessoa usar regularmente álcool, o que pensa a respeito de uma pessoa usar regularmente maconha, o que pensa a respeito de uma pessoa usar regularmente cocaína, o que pensa a respeito de uma pessoa usar regularmente crack, o que pensa a respeito de uma pessoa usar regularmente tranqüilizantes, o que pensa a respeito de uma pessoa usar regularmente anfetaminas e o que pensa a respeito de uma pessoa usar regularmente inalantes). Foi realizado um teste qui-quadrado para cada uma e foram eliminadas as variáveis com $p>0,05$. Para os casos em que o teste qui-quadrado não fosse adequado foi feita uma análise descritiva para avaliar a associação com a resposta; na dúvida a variável foi mantida.

A seguir foram ajustados oito modelos, um para cada grupo de variáveis (perfil do aluno, ambiente familiar, curso universitário, vida acadêmica, grupo de amigos, lazer, uso pessoal de drogas e atitudes relacionadas às drogas). O método utilizado foi o Backward (todas as variáveis foram incluídas a princípio e as não significantes foram sendo excluídas uma a uma).

Depois disso foi ajustado um modelo único, reunindo todas as variáveis que ficaram mantidas nos oito modelos. O mesmo critério de exclusão foi utilizado. A categoria de referência foi a de menor uso de álcool/drogas. 


\section{RESULTADOS}

Totalizou-se 2837 questionários válidos o que corresponde a 83,61\% da amostra sorteada. Dos 2865 coletados, 28 foram excluídos por terem a pergunta 63 respondida afirmativamente. Esta questão, caso fosse respondida afirmativamente, implicaria a exclusão do questionário. Ela foi elaborada com opções de resposta falsas e tinha a finalidade de controlar a fidedignidade das respostas ao questionário. $\mathrm{Na}$ impossibilidade de uma resposta verdadeira, quem assinalou "sim" em alguma resposta, muito provavelmente, o fez, ou por querer assinalar uma resposta falsa, ou por não ter lido, atentamente o suficiente, as opções de resposta, para ter compreendido seus enunciados. Em ambos os casos, as respostas que este aluno deu para as outras perguntas tornaram-se suspeitas de não expressarem realmente 0 que $o$ aluno pensa e fez.

\subsection{Perfil sócio-demográfico}

Observa-se que a distribuição dos questionários aplicados manteve proporção entre as três áreas em que os cursos de graduação estão divididos (tabela 4). Como descrito no Plano de Amostragem do projeto original, foi utilizado o método de partilha igual para a realização do cálculo do tamanho da amostra entre as três áreas. 
Tabela 4 - Distribuição dos questionários válidos por área.

\begin{tabular}{lrr}
\hline Área & № & $\%$ \\
\hline Humanas & 956 & 33,70 \\
Biológicas & 927 & 32,68 \\
Exatas & 954 & 33,63 \\
\hline Total & 2837 & 100.00 \\
\hline
\end{tabular}

Tabela 5 - Distribuição dos questionários válidos por unidade.

\begin{tabular}{|c|c|c|c|c|c|}
\hline & & & & & \\
\hline & & & Unidade & № & $\%$ \\
\hline & & & $\overline{E C A}$ & 104 & 3,67 \\
\hline & & & $\mathrm{EE}$ & 74 & 2,61 \\
\hline & & & EEFE & 94 & 3,31 \\
\hline & & & EP & 508 & 17,91 \\
\hline & & & FAU & 50 & 1,76 \\
\hline & & & FCF & 127 & 4,48 \\
\hline & & & FD & 158 & 5,57 \\
\hline FE & 18 & 0,63 & & & \\
\hline & & & FEA & 201 & 7,08 \\
\hline & & & FFLCH & 425 & 14,98 \\
\hline & & & FM & 216 & 7,61 \\
\hline & & & FMVZ & 54 & 1,90 \\
\hline & & & $\mathrm{FO}$ & 108 & 3,81 \\
\hline & & & FSP & 40 & 1,41 \\
\hline & & & IAG & 24 & 0,85 \\
\hline & & & IB & 124 & 4,37 \\
\hline & & & IF & 162 & 5,71 \\
\hline & & & IGC & 35 & 1,23 \\
\hline & & & IME & 171 & 6,03 \\
\hline & & & IP & 90 & 3,17 \\
\hline & & & $\mathrm{IQ}$ & 54 & 1,90 \\
\hline & & & Total & 2837 & 100.00 \\
\hline
\end{tabular}


Quanto ao ano de ingresso, a maior parte dos questionários foi respondida por alunos que ingressaram na USP entre os anos de 1997 e 2000 (tabela 6).

Tabela 6 - Distribuição dos questionários válidos por ano de ingresso.

\begin{tabular}{lrr}
\hline $\begin{array}{l}\text { Ano de } \\
\text { Ingresso }\end{array}$ & № & $\%$ \\
\hline 1981 & 1 & 0,04 \\
1986 & 1 & 0,04 \\
1987 & 1 & 0,04 \\
1988 & 1 & 0,04 \\
1989 & 5 & 0,15 \\
1990 & 7 & 0,25 \\
1991 & 7 & 0,25 \\
1992 & 13 & 0,46 \\
1993 & 20 & 0,71 \\
1994 & 34 & 1,20 \\
1995 & 79 & 2,80 \\
1996 & 208 & 7,36 \\
1997 & 359 & 12,71 \\
1998 & 544 & 19,23 \\
1999 & 645 & 22,83 \\
2000 & 756 & 26,76 \\
2001 & 144 & 5,10 \\
\hline Total & 2825 & 100,00 \\
\hline Brancos e nulos & 12 & \\
\hline
\end{tabular}


Pela tabela abaixo (tabela 7), observa-se que a maior parte dos alunos da nossa amostra estava cursando entre o primeiro e o quarto ano em 2000.

Tabela 7 - Distribuição dos questionários válidos por ano que cursou em 2000.

\begin{tabular}{lrr}
\hline Ano & № & $\%$ \\
\hline 1 & 762 & 28,70 \\
2 & 709 & 26,70 \\
3 & 582 & 21,92 \\
4 & 387 & 14,58 \\
5 & 162 & 6,10 \\
6 & 53 & 2,00 \\
\hline Total & 2655 & 100,00 \\
\hline Brancos e nulos & 182 & \\
\hline
\end{tabular}

A maior parte da nossa amostra, (76,08\%), estava cursando o período diurno (matutino e integral) por ocasião da pesquisa (tabela 8).

Tabela 8 - Distribuição dos questionários válidos por período do curso

\begin{tabular}{lrr}
\hline Período & № & $\%$ \\
\hline Diurno & 2137 & 76,08 \\
Noturno & 672 & 23,92 \\
\hline Total & 2809 & 100,00 \\
\hline Brancos e nulos & 28 & \\
\hline
\end{tabular}

Tabela 9 - Distribuição dos questionários válidos por sexo.

\begin{tabular}{lrr}
\hline Sexo & № & $\%$ \\
\hline masculino & 1631 & 57,78 \\
feminino & 1192 & 42,22 \\
\hline Total & 2823 & 100,00 \\
\hline Brancos e nulos & 14 & \\
\hline
\end{tabular}

A faixa etária que concentrou a maior parte dos questionários foi entre 20 e 24 anos $(67,71 \%)$ (tabela 10$)$.

Tabela 10 - Distribuição dos questionários válidos por idade.

Idade № $\%$




\begin{tabular}{lrr}
$15-19$ & 396 & 14,04 \\
$20-24$ & 1910 & 67,71 \\
$25-29$ & 336 & 11,91 \\
30 ou + & 179 & 6,34 \\
\hline Total & 2821 & 100,00 \\
\hline Brancos e nulos & 16 & \\
\hline
\end{tabular}

Nas tabelas seguintes (11, 12 e 13), observa-se que os alunos, em sua maioria, são solteiros, não têm filhos e vivem com os pais.

Tabela 11 - Distribuição dos questionários válidos por estado civil.

\begin{tabular}{lrr}
\hline Estado civil & № & $\%$ \\
\hline Solteiro(a) & 2608 & 92,42 \\
Casado(a)/vive junto & 168 & 5,95 \\
Separado(a) & 42 & 1,49 \\
Viúvo(a) & 4 & 0,14 \\
\hline Total & 2822 & 100,00 \\
\hline Brancos e nulos & 15 & \\
\hline
\end{tabular}

Tabela 12 - Distribuição dos questionários válidos ter ou não filhos.

\begin{tabular}{lrr}
\hline Ter filhos & № & $\%$ \\
\hline Sim & 147 & 5,21 \\
Não & 2674 & 94,79 \\
\hline Total & 2821 & 100,00 \\
\hline Brancos e nulos & 16 & \\
\hline
\end{tabular}

Tabela 13 - Distribuição dos questionários válidos por situação de moradia.

\begin{tabular}{lrr}
\hline Mora com: & № & $\%$ \\
\hline Pais/familiares & 2089 & 74,16 \\
Cônjuge & 169 & 6,00 \\
Amigos/república & 287 & 10,19 \\
Sozinho & 165 & 5,86 \\
CRUSP & 68 & 2,41 \\
outro & 39 & 1,38 \\
\hline Total & 2817 & 100,00 \\
\hline Brancos e nulos & 20 & \\
\hline
\end{tabular}


Os alunos possuem alguma religião,

principalmente a católica, mas não a praticam

(tabelas 14, 15 e 16).

Tabela 14 - Distribuição dos questionários válidos por ter ou não religião.

\begin{tabular}{lrr}
\hline Religião & $№$ & $\%$ \\
\hline sim & 1802 & 64,17 \\
não & 1006 & 35,83 \\
\hline Total & 2808 & 100,00 \\
\hline Brancos e nulos & 29 & \\
\hline
\end{tabular}

Tabela 15 - Distribuição dos questionários válidos por tipo de religião.

\begin{tabular}{lrr}
\hline Religião & № & $\%$ \\
\hline Católica & 1179 & 64,32 \\
Espírita & 242 & 13,20 \\
Protestante & 173 & 9,44 \\
Outras & 239 & 13,04 \\
\hline Total & 1833 & 100,00 \\
\hline Brancos e nulos & 1004 & \\
\hline
\end{tabular}


Tabela 16 - Distribuição dos questionários válidos por prática ou não da religião.

\begin{tabular}{lrr}
\hline Pratica religião & № & $\%$ \\
\hline sim & 909 & 40,42 \\
não & 1340 & 59,58 \\
\hline Total & 2249 & 100,00 \\
\hline Brancos e nulos & 588 & \\
\hline
\end{tabular}

A maior parte exerceu algum tipo de atividade remunerada nos últimos seis meses (tabela 17).

Tabela 17 - Distribuição dos questionários válidos por exercício de alguma atividade remunerada por período maior que um mês nos últimos 6 meses.

\begin{tabular}{lrr}
\hline Atividade & & \\
Remunerada & $N$ & $\%$ \\
\hline sim & 1645 & 58,62 \\
não & 1161 & 41,38 \\
\hline Total & 2806 & 100,00 \\
\hline Brancos e nulos & 31 & \\
\hline
\end{tabular}

\section{A maioria possui pai e mãe com diploma de}

\section{curso superior (tabelas 18 e 19).}

Tabela 18 - Distribuição dos questionários válidos por grau de escolaridade do pai.

\begin{tabular}{lrr}
\hline Escolaridade & № & $\%$ \\
\hline Não teve educação formal & 24 & 0,86 \\
Primeiro grau incompleto & 272 & 9,69 \\
Primeiro grau completo & 162 & 5,77 \\
Segundo grau incompleto & 102 & 3,63 \\
Segundo grau completo & 397 & 14,14 \\
Superior incompleto & 241 & 8,59 \\
Superior completo & 1595 & 56,82 \\
Não sei & 14 & 0,50 \\
\hline Total & 2807 & 100,00 \\
\hline Brancos e nulos & 30 & \\
\hline
\end{tabular}


Tabela 19 - Distribuição dos questionários válidos por grau de escolaridade da mãe.

\begin{tabular}{lrr}
\hline Escolaridade & № & $\%$ \\
\hline Não teve educação formal & 25 & 0,89 \\
Primeiro grau incompleto & 294 & 10,45 \\
Primeiro grau completo & 232 & 8,24 \\
Segundo grau incompleto & 131 & 4,66 \\
Segundo grau completo & 531 & 18,87 \\
Superior incompleto & 249 & 8,85 \\
Superior completo & 1342 & 47,68 \\
Não sei & 10 & 0,36 \\
\hline Total & 2814 & 100,00 \\
\hline Brancos e nulos & 23 & \\
\hline
\end{tabular}

Apesar da renda familiar ser bem distribuída entre as diversas faixas investigadas, a maior parte das famílias dos alunos concentra-se nas faixas entre 11 até 30 salários mínimos (tabela 20).

Tabela 20 - Distribuição dos questionários válidos por renda familiar em número de salários mínimos.

\begin{tabular}{lrr}
\hline Salários mínimos & № & $\%$ \\
\hline até 10 & 550 & 20,42 \\
de 11 a 20 & 685 & 25,43 \\
de 21 a 30 & 643 & 23,87 \\
de 31 a 40 & 334 & 12,40 \\
mais de 40 & 482 & 17,88 \\
\hline Total & 2694 & 100,00 \\
\hline Brancos e nulos & 143 & \\
\hline
\end{tabular}


5.2 Informações e atitudes sobre o uso de drogas

A maioria dos estudantes que já experimentou alguma droga ilicitamente (exceto álcool e tabaco), o fez por curiosidade ou por diversão e prazer (tabela 21).

\section{Tabela 21 - Distribuição dos questionários válidos pelos motivos para o uso de drogas (exceto álcool e tabaco) pela primeira vez.}

\begin{tabular}{lrr}
\hline Motivos para o uso de drogas pela primeira vez & № & $\%$ \\
\hline Nunca experimentei drogas & 1546 & 57,84 \\
Não sei & 54 & 2,02 \\
Prática religiosa & 4 & 0,15 \\
Para me relacionar melhor com outras pessoas & 19 & 0,71 \\
Diversão ou prazer & 352 & 13,17 \\
Porque meus amigos/namorada(o) usam & 15 & 0,56 \\
Por curiosidade & 577 & 21,59 \\
Alívio de tensão psicológica & 53 & 1,98 \\
Aumentar o desempenho no estudo & 2 & 0,07 \\
Outro & 51 & 1,91 \\
\hline Total & 2673 & 100,00 \\
\hline Brancos e nulos & 164 & \\
\hline
\end{tabular}

\section{A maior parte dos alunos fez o primeiro uso}

\section{de drogas (exceto álcool e tabaco) com amigos}

$$
\text { ou companheiros (tabela 22). }
$$

Tabela 22 - Distribuição dos questionários válidos pelo tipo de pessoa que introduziu no uso de drogas (exceto álcool e tabaco).

\begin{tabular}{lrr}
\hline Tipo de pessoa & № & $\%$ \\
\hline Não fiz uso & 1588 & 58,68 \\
Familiares & 47 & 1,74 \\
Colegas de faculdade/amigos/conhecidos & 888 & 32,82 \\
Namorado(a)/companheiro(a) & 38 & 1,40 \\
Profissionais de saúde & 24 & 0,89 \\
Outros & 121 & 4,47 \\
\hline Total & 2706 & 100,00 \\
\hline
\end{tabular}


Foi calculado que $28,09 \%$ dos estudantes experimentou algum tipo de droga ilícita antes de entrar na USP (tabela 23). A proporção de alunos que usou drogas na vida foi de 38\% (ANDRADE et al., 1997). Estima-se então que 10\% dos estudantes que já experimentaram algum tipo de droga na vida o fizeram depois de ter ingressado na universidade, no entanto, a maioria experimentou antes de entrar na USP.

\section{Tabela 23 - Distribuição dos questionários válidos por ter experimentado drogas (exceto álcool e tabaco) sem prescrição médica antes de entrar na universidade.}

\begin{tabular}{lrr}
\hline $\begin{array}{lrr}\text { Você experimentou drogas antes de entrar } \\
\text { na USP }\end{array}$ & № & $\%$ \\
\hline Sim & 771 & 28.09 \\
Não & 1974 & 71.91 \\
\hline Total & 2745 & 100.00 \\
\hline Brancos e nulos & 92 & \\
\hline
\end{tabular}

As drogas mais experimentadas antes de entrar na universidade foram a maconha, os inalantes, os alucinógenos e a cocaína (tabela 24).

\section{Tabela 24 - Distribuição dos questionários válidos por tipo de drogas experimentado (exceto álcool e tabaco) sem prescrição médica antes de entrar na universidade}

\begin{tabular}{lrrrrrr}
\hline & Sim & $\%$ & Não & $\%$ & Total & $\begin{array}{r}\text { Brancos e } \\
\text { nulos }\end{array}$ \\
\hline Maconha & 656 & 83,78 & 127 & 16,22 & 783 & 2054 \\
Alucinógenos & 143 & 18,29 & 639 & 81,71 & 782 & 2055 \\
Cocaína & 110 & 14,07 & 672 & 85,93 & 782 & 2055 \\
Crack & 22 & 2,82 & 759 & 97,18 & 781 & 2056 \\
Anfetamina & 70 & 8,95 & 712 & 91,05 & 782 & 2055 \\
Anti-colinérgico & 22 & 2,82 & 759 & 97,18 & 781 & 2056 \\
Solventes & 341 & 43,66 & 440 & 56,34 & 781 & 2056 \\
Tranqüilizantes & 63 & 8,07 & 718 & 91,93 & 781 & 2056 \\
Opiáceos & 17 & 2,18 & 764 & 97,82 & 781 & 2056 \\
Sedativos & 23 & 2,94 & 758 & 97,06 & 781 & 2056
\end{tabular}


Dos que fazem uso freqüente de drogas, a maior parte o faz para curtir seus

efeitos (tabela 25).

\section{Tabela 25 - Distribuição dos questionários válidos por motivos para o uso freqüente de drogas.}

\begin{tabular}{lrr}
\hline Motivos para o uso freqüente de drogas & № & $\%$ \\
\hline Não faço & 2279 & 85,07 \\
Para participar de grupo de amigos e/ou colegas da faculdade & 63 & 2,35 \\
Para quebrar a rotina & 75 & 2,80 \\
Para curtir os efeitos da droga & 162 & 6,05 \\
Para diminuir a ansiedade ou aliviar o estresse e relaxar & 97 & 3,62 \\
Para evitar ou aliviar os sintomas de abstinência & 3 & 0,11 \\
\hline Total & 2679 & 100,00 \\
\hline Brancos e nulos & 158 & \\
\hline
\end{tabular}

A maior parte dos alunos que usam drogas, o faz com os amigos de faculdade (tabela 26).

\section{Tabela 26 - Distribuição dos questionários válidos por tipo de pessoa com quem usa com mais freqüência drogas.}

\begin{tabular}{lrr}
\hline Com quem usa com mais freqüência drogas & № & $\%$ \\
\hline Não uso & 2245 & 84,58 \\
Sozinho & 43 & 1,62 \\
Com amigos/colegas de faculdade & 307 & 11,57 \\
Com irmãos, primos, outros familiares & 15 & 0,57 \\
Com o meu companheiro(a) & 34 & 1,28 \\
Com estranhos & 2 & 0,08 \\
Outros & 8 & 0,30 \\
\hline Total & 2654 & 100,00 \\
\hline Brancos e nulos & 183 & \\
\hline
\end{tabular}


Dos alunos que usam com freqüência drogas, a maioria percebe interferências no sono, nos estudos e na prática esportiva (tabela 27).

\section{Tabela 27 - Distribuição dos questionários válidos pelo tipo de interferência que o uso freqüente de drogas causa.}

\begin{tabular}{lrrrrrr}
\hline & Sim & $\%$ & Não & $\%$ & Total & $\begin{array}{r}\text { Brancos e } \\
\text { nulos }\end{array}$ \\
\hline Não faço & 2239 & 83,39 & 446 & 16,61 & 2685 & 152 \\
Na sua alimentação & 111 & 4,13 & 2577 & 95,87 & 2688 & 149 \\
No seu sono & 145 & 5,39 & 2543 & 94,61 & 2688 & 149 \\
Nos seus estudos & 138 & 5,13 & 2550 & 94,87 & 2688 & 149 \\
No seu desempenho & & & & & & \\
sexual & 62 & 2,31 & 2626 & 97,69 & 2688 & 149 \\
No seu trabalho & 67 & 2,49 & 2621 & 97,51 & 2688 & 149 \\
Nas suas relações & & & & & & \\
sociais/afetivas & 99 & 3,68 & 2589 & 96,32 & 2688 & 149 \\
Na sua prática esportiva & 110 & 4,09 & 2578 & 95,91 & 2688 & 149 \\
Outros & 35 & 1,30 & 2653 & 98,70 & 2688 & 149 \\
Não interfere & 179 & 6,66 & 2509 & 93,34 & 2688 & 149 \\
\hline
\end{tabular}

A maioria nunca se envolveu em acidentes de automóvel após o uso de algum tipo de droga (tabela 28).

Tabela 28 - Distribuição dos questionários válidos por envolvimento em algum acidente de carro após o consumo de álcool e drogas, nos últimos 12 meses.

\begin{tabular}{lrr}
\hline Envolvimento em acidentes de automóvel & № & $\%$ \\
\hline Sim & 70 & 2,51 \\
Não & 2724 & 97,49 \\
\hline Total & 2794 & 100,00 \\
\hline Brancos e nulos & 43 & \\
\hline
\end{tabular}


A maior parte dos alunos não possui algum membro da família com problemas de álcool (tabela 29).

\section{Tabela 29 - Distribuição dos questionários válidos por uso de álcool por algum membro da família com prejuízos ao convívio social, familiar e profissional nos últimos 12 meses.}

\begin{tabular}{lrr}
\hline $\begin{array}{lrr}\text { Uso prejudicial de álcool por algum membro } \\
\text { da família }\end{array}$ & № & $\%$ \\
\hline Sim & 367 & 13,09 \\
Não & 2437 & 86,91 \\
\hline Total & 2804 & 100,00 \\
\hline Brancos e nulos & 33 & \\
\hline
\end{tabular}

As pessoas da convivência social dos alunos que mais fazem uso freqüente de drogas são os amigos. E as drogas mais utilizadas são o tabaco, álcool e a maconha (tabela 30).

\section{Tabela 30 - Distribuição dos questionários válidos por uso freqüente de drogas por algum membro da família ou amigos.}

\begin{tabular}{lrrrrrrrrrr}
\hline & & & & & & & & \multicolumn{3}{c}{ Nenhum } \\
& Pai & $\%$ & Mãe & $\%$ & Irmão & $\%$ & Amigos & $\%$ & deles & $\%$ \\
Álcool & 559 & 23,01 & 147 & 6,04 & 293 & 12,05 & 1197 & 49,24 & 961 & 39,56 \\
Tabaco & 388 & 16,17 & 322 & 13,42 & 306 & 12,74 & 1296 & 53,98 & 772 & 32,18 \\
Maconha & 10 & 0,44 & 6 & 0,26 & 123 & 5,37 & 918 & 40,03 & 1322 & 57,70 \\
Anfetaminas & 1 & 0,05 & 5 & 0,24 & 9 & 0,43 & 114 & 5,44 & 1951 & 93,22 \\
Cocaína & 2 & 0,09 & 0 & 0,00 & 8 & 0,38 & 144 & 6,81 & 1946 & 91,97 \\
Crack & 0 & 0,00 & 0 & 0,00 & 0 & 0,00 & 32 & 1,54 & 2024 & 97,54 \\
Inalantes & 0 & 0,00 & 0 & 0,00 & 16 & 0,75 & 250 & 11,78 & 1852 & 87,28 \\
Tranqüilizantes & 16 & 0,76 & 36 & 1,71 & 11 & 0,52 & 88 & 4,18 & 1949 & 92,68 \\
Ecstasy & 0 & 0,00 & 1 & 0,05 & 5 & 0,24 & 135 & 6,42 & 1945 & 92,49 \\
\hline
\end{tabular}


5.3 Uso de drogas entre os estudantes

Observa-se que as principais drogas de consumo na vida pelos estudantes da USP são: álcool, tabaco, maconha, inalantes e alucinógenos.

\section{Tabela 31 - Distribuição dos questionários válidos por tipo de droga utilizada na vida.}

\begin{tabular}{lrrrrrr}
\hline \multicolumn{9}{c}{ NA VIDA } \\
\hline DROGA & USOU & $\%$ & NÃO USOU & BRANCOS NULOS TOTAL \\
\hline Álcool & 2626 & 91,90 & 203 & 34 & 2 & 2837 \\
Tabaco & 1392 & 50,50 & 1437 & 34 & 2 & 2837 \\
Maconha & 940 & 35,30 & 1892 & 32 & 1 & 2837 \\
Alucinógenos & 306 & 11,40 & 2521 & 37 & 1 & 2837 \\
Cocaina & 169 & 5,90 & 2664 & 31 & 1 & 2837 \\
Crack & 27 & 0,90 & 2803 & 33 & 2 & 2837 \\
Anfetaminas & 258 & 9,00 & 2564 & 42 & 1 & 2837 \\
Anticolinérgico & 73 & 2,90 & 2750 & 41 & 1 & 2837 \\
Tranquilizantes & 179 & 6,31 & 2635 & 49 & 2 & 2837 \\
Opiáceos & 36 & 1,27 & 2787 & 41 & 1 & 2837 \\
Sedativos & 44 & 1,55 & 2781 & 39 & 1 & 2837 \\
Anabolizantes & 12 & 0,40 & 2815 & 37 & 1 & 2837 \\
Inalantes & 696 & 24,50 & 2111 & 58 & 0 & 2837 \\
Ecstasy & 90 & 3,17 & 2715 & 60 & 0 & 2837 \\
\hline
\end{tabular}


Na tabela abaixo se observa que nos últimos 12 meses as drogas mais consumidas pelos estudantes foram: álcool, tabaco, maconha, inalantes, anfetaminas e alucinógenos.

\section{Tabela 32 - Distribuição dos questionários válidos por tipo de droga utilizada nos últimos 12 meses.}

\begin{tabular}{lrrrrrr}
\hline \multicolumn{7}{c}{ ÚLTIMOS 12 MESES } \\
\hline DROGA & USOU & $\%$ & NÃO USOU & BRANCOS NULOS TOTAL \\
\hline Álcool & 2292 & 80,70 & 533 & 37 & 3 & 2837 \\
Tabaco & 698 & 24,60 & 2105 & 61 & 1 & 2837 \\
Maconha & 600 & 22,80 & 2201 & 63 & 1 & 2837 \\
Alucinógenos & 141 & 4,90 & 2651 & 72 & 1 & 2837 \\
Cocaina & 68 & 2,40 & 2720 & 76 & 1 & 2837 \\
Crack & 5 & 0,18 & 2780 & 79 & 1 & 2837 \\
Anfetaminas & 151 & 5,30 & 2633 & 80 & 1 & 2837 \\
Anticolinérgico & 18 & 0,63 & 2760 & 86 & 1 & 2837 \\
Tranquilizantes & 98 & 3,45 & 2680 & 86 & 1 & 2837 \\
Opiáceos & 15 & 0,53 & 2763 & 86 & 1 & 2837 \\
Sedativos & 20 & 0,70 & 2757 & 87 & 1 & 2837 \\
Anabolizantes & 9 & 0,32 & 2769 & 86 & 1 & 2837 \\
Inalantes & 385 & 13,49 & 2391 & 89 & 0 & 2837 \\
Ecstasy & 46 & 1,62 & 2713 & 105 & 1 & 2837 \\
\hline & & & & & &
\end{tabular}


$\mathrm{Na}$ tabela 33, podemos observar que as drogas mais consumidas nos últimos 30 dias foram: álcool, tabaco, maconha, inalantes e anfetaminas.

\section{Tabela 33 - Distribuição dos questionários válidos por tipo de droga utilizada nos últimos 30 dias.}

\begin{tabular}{lrrrrrr}
\hline \multicolumn{7}{c}{ ÚLTIMOS 30 DIAS } \\
\hline DROGA & USOU & $\%$ & NÃO USOU & BRANCOS & NULOS & TOTAL \\
\hline Álcool & 1987 & 70,04 & 810 & 65 & 3 & 2837 \\
Tabaco & 572 & 20,16 & 2164 & 128 & 1 & 2837 \\
Maconha & 430 & 16,91 & 2317 & 112 & 6 & 2837 \\
Alucinógenos & 72 & 2,54 & 2682 & 110 & 1 & 2837 \\
Cocaína & 35 & 1,23 & 2720 & 109 & 1 & 2837 \\
Crack & 5 & 0,18 & 2754 & 105 & 1 & 2837 \\
Anfetaminas & 93 & 3,41 & 2656 & 114 & 2 & 2837 \\
Anticolinérgico & 10 & 0,35 & 2744 & 110 & 1 & 2837 \\
Tranquilizantes & 64 & 2,26 & 2685 & 115 & 1 & 2837 \\
Opiáceos & 11 & 0,39 & 2745 & 108 & 1 & 2837 \\
Sedativos & 14 & 0,49 & 2743 & 107 & 1 & 2837 \\
Anabolizantes & 4 & 0,14 & 2755 & 105 & 1 & 2837 \\
Inalantes & 191 & 6,51 & 2527 & 147 & 0 & 2837 \\
Ecstasy & 27 & 0,95 & 2704 & 134 & 0 & 2837 \\
\hline
\end{tabular}

\subsubsection{Resultados comparando as áreas de}

\section{Biológicas e Humanas (Tabela anexo D)}

Têm prevalências iguais:

Na Vida: Crack, Anfetamina, Opiáceos, Anabolizantes, Inalantes

Nos últimos 12 meses: Alucinógenos, Crack, Anfetaminas, Tranqüilizantes, Opiáceos, Sedativos, Anabolizantes, Inalantes, Ecstasy.

Nos últimos 30 dias: Alucinógenos, Cocaína, Crack, Anfetaminas, Anticolinérgicos, Tranqüilizantes, Opiáceos, Anabolizantes, Ecstasy.

Biológicas consomem mais do que Humanas

Na Vida: Álcool

Nos últimos 12 meses: Álcool

Nos últimos 30 dias: Álcool e Inalantes 


\section{Humanas consomem mais do que Biológicas}

Na vida: Tabaco, Maconha, Alucinógenos, Cocaína, Anti - colinérgicos, Tranqüilizantes, Sedativos, Ecstasy.

Nos Últimos 12 meses: Tabaco, Maconha, Cocaína, Anti-colinérgicos,

Nos últimos 30 dias: Tabaco, Maconha, sedativos.

\subsubsection{Resultados comparando as áreas de Humanas e Exatas (Tabela anexo D)}

Têm prevalências iguais:

Na vida: Álcool, Crack, Anfetaminas, Sedativos, Anabolizantes.

Nos últimos 12 meses: Álcool, Alucinógenos, Crack, Anti-colinérgicos, Opiáceos, Sedativos, Anabolizantes.

Nos últimos 30 dias: Álcool, Alucinógenos, Crack, Anfetaminas, Anticolinérgicos, Opiáceos, Anabolizantes, Inalantes.

Exatas consomem mais do que Humanas

Nenhuma droga

Humanas consomem mais do que Exatas

Na vida: Tabaco, Maconha, Alucinógenos, Cocaína, Anti-colinérgico, Tranqüilizantes, Opiáceos, Inalantes, Ecstasy.

Nos últimos 12 meses: Tabaco, Maconha, Cocaína, Anfetaminas,

Tranqüilizantes, Inalantes, Ecstasy.

Nos últimos 30 dias: Tabaco, Maconha, Cocaína, Tranqüilizantes, Sedativos, Ecstasy.

\subsubsection{Resultados comparando as áreas de Biológicas e Exatas (Tabela anexo D)}

Têm prevalências iguais

Na vida: Álcool, Tabaco, Maconha, Alucinógenos, Cocaína, Crack, Anticolinérgico, Tranqüilizantes, Opiáceos, Sedativos, Anabolizantes, Ecstasy,

Nos últimos 12 meses: Álcool, Tabaco, Maconha, Alucinógenos, Cocaína, Crack, 
Anti-colinérgicos, Tranqüilizantes, Opiáceos, Sedativos, Anabolizantes, Ecstasy.

Nos últimos 30 dias: Tabaco, Maconha, Alucinógenos, Cocaína, Crack, Anfetaminas, Anti-colinérgicos, Tranqüilizantes, Opiáceos, Sedativos, Anabolizantes, Ecstasy.

Biológicas consomem mais do que Exatas

\section{Na vida: Inalantes, Anfetaminas.}

Nos últimos 12 meses: Inalantes, Anfetaminas.

Nos últimos 30 dias: Inalantes, Álcool

Exatas consomem mais do que biológicas

Nenhuma droga

\subsubsection{Resultados comparando Homens e Mulheres (Tabela anexo E)}

Têm prevalências iguais

Na vida:Tabaco, Anti-colinérgico, Tranqüilizantes, Opiáceos, Sedativos, Ecstasy.

Nos últimos 12 meses: Tabaco, Crack, Anfetaminas, Anti-colinérgicos, Sedativos, Anabolibantes, Ecstasy.

Nos últimos 30 dias: Tabaco, Cocaína, Crack, Anfetaminas, Anti-colinérgicos, Opiáceos, Sedativos, Anabolibantes, Ecstasy.

Homens consomem mais do que mulheres

Na vida: Álcool, Inalantes, Anabolizantes, Crack, Cocaína, Alucinógenos, Maconha.

Nos últimos 12 meses: Álcool, Inalantes, Cocaína, Alucinógenos, Maconha.

Nos últimos 30 dias: Álcool, Inalantes, Alucinógenos, Maconha.

Mulheres consomem mais do que homens

Na vida: Anfetaminas

Nos últimos 12 meses: Tranqüilizantes, Opiáceos.

Nos últimos 30 dias: Tranqüilizantes. 


\title{
5.3.5 Resultados comparando os períodos Noturno e Diurno (Tabela anexo F)
}

Têm prevalências iguais

Na vida: Álcool, Tabaco, Alucinógeno, Crack, Anfetaminas, Anti-colinérgicos, Tranqüilizantes, Opiáceos, Sedativos, Anabolizantes, Inalantes, Ecstasy.

Nos últimos 12 meses: Álcool, Tabaco, Maconha, Alucinógenos, Cocaína, Anfetaminas, Anti-colinérgico, Tranqüilizantes, Opiáceos, Sedativos, Anabolizantes, Ecstasy.

Nos últimos 30 dias: Álcool, Tabaco, Alucinógeno s, Maconha, Cocaína, Crack, Anfetaminas, Anti-colinérgicos, Tranqüilizantes, Sedativos, Anabolizantes, Ecstasy.

Alunos do período Diurno consomem mais do que os do Noturno

Nos últimos 12 meses: Inalantes, Crack.

Nos últimos 30 dias: Inalantes, Opiáceos.

Alunos do período Noturno consomem mais do que os do Diurno

Na vida: Cocaína, Maconha.

\subsubsection{Comparação entre a pesquisas realizadas em}

\section{6 e 2001.}

As tabelas 34, 35 e 36 indicam as drogas que apresentaram aumento significativo com relação à primeira pesquisa realizada em 1996. As outras drogas investigadas em nossa pesquisa não apresentaram alteração significativa em seu consumo. Nenhuma droga apresentou diminuição significativa de consumo entre os dois momentos investigados.

\section{Podemos ver que as drogas que}

\section{apresentaram aumento significativo de}

\author{
consumo na vida foram: álcool, tabaco,
}


colinérgicos, inalantes, barbitúricos e ilegais

(tabela 34). 
Tabela 34 - Drogas que apresentaram diferença estatisticamente significante a partir da comparação entre a proporções de alunos que fizeram uso de alguma droga na vida por tipo de droga, área de estudo e total das pesquisas realizadas em 1996 e 2001. (Intervalo de confiança $95 \%$ ).

\begin{tabular}{|c|c|c|c|c|c|c|c|c|}
\hline & & \multicolumn{7}{|c|}{ Uso na vida } \\
\hline & & \multicolumn{2}{|c|}{1996} & \multicolumn{2}{|c|}{2001} & \multirow{2}{*}{$\frac{\text { Diferença }}{\text { total USP }}$} & \multicolumn{2}{|c|}{$\begin{array}{c}\text { Intervalo para a } \\
\text { diferença }\end{array}$} \\
\hline & & total & total USP & total & total USP & & & \\
\hline \multirow[t]{3}{*}{ Álcool } & Humanas & 0,870 & 0,885 & 0,904 & 0,919 & 0,034 & 0,009 & 0,057 \\
\hline & Exatas & 0,902 & & 0,931 & & & & \\
\hline & Biológicas & 0,911 & & 0,948 & & & & \\
\hline \multirow[t]{3}{*}{ Tabaco } & Humanas & 0,440 & 0,428 & 0,541 & 0,505 & 0,077 & 0,049 & 0,104 \\
\hline & Exatas & 0,395 & & 0,442 & & & & \\
\hline & Biológicas & 0,445 & & 0,482 & & & & \\
\hline \multirow[t]{3}{*}{ Maconha } & Humanas & 0,327 & 0,311 & 0,399 & 0,353 & 0,042 & 0,016 & 0,067 \\
\hline & Exatas & 0,268 & & 0,286 & & & & \\
\hline & Biológicas & 0,328 & & 0,301 & & & & \\
\hline \multirow[t]{3}{*}{ Alucinógenos } & s Humanas & 0,074 & 0,061 & 0,132 & 0,114 & 0,053 & 0,039 & 0,066 \\
\hline & Exatas & 0,040 & & 0,090 & & & & \\
\hline & Biológicas & 0,056 & & 0,092 & & & & \\
\hline \multirow[t]{3}{*}{ Anfetaminas } & Humanas & 0,054 & 0,048 & 0,096 & 0,090 & 0,042 & 0,030 & 0,053 \\
\hline & Exatas & 0,026 & & 0,069 & & & & \\
\hline & Biológicas & 0,066 & & 0,102 & & & & \\
\hline \multirow{3}{*}{$\begin{array}{l}\text { Anti- } \\
\text { colinérgicos }\end{array}$} & & & & & & & & \\
\hline & $\begin{array}{l}\text { Humanas } \\
\text { Exatas }\end{array}$ & $\begin{array}{l}0,011 \\
0.011\end{array}$ & 0,011 & $\begin{array}{l}0,039 \\
0,017\end{array}$ & 0,029 & 0,018 & 0,012 & 0,023 \\
\hline & Biológicas & 0,013 & & 0,016 & & & & \\
\hline \multirow[t]{3}{*}{ Inalantes } & Humanas & 0,179 & 0,179 & 0,254 & 0,245 & 0,066 & 0,045 & 0,086 \\
\hline & Exatas & 0,168 & & 0,193 & & & & \\
\hline & Biológicas & 0,200 & & 0,291 & & & & \\
\hline \multirow[t]{3}{*}{ Barbitúricos } & Humanas & 0,011 & 0,010 & 0,022 & 0,017 & 0,007 & 0,001 & 0,012 \\
\hline & Exatas & 0,009 & & 0,010 & & & & \\
\hline & Biológicas & 0,011 & & 0,008 & & & & \\
\hline \multirow[t]{3}{*}{ llegais } & Humanas & 0,410 & 0,394 & 0,488 & 0,451 & 0,057 & 0,027 & 0,087 \\
\hline & Exatas & 0,343 & & 0,367 & & & & \\
\hline & Biológicas & 0,421 & & 0,456 & & & & \\
\hline
\end{tabular}


$\mathrm{Na}$ tabela abaixo, podemos observar que as drogas que apresentaram aumento significativo nos últimos 12 meses foram: maconha, alucinógenos, anfetaminas, inalantes e ilegais.

\section{Tabela 35 - Drogas que apresentaram diferença estatisticamente significante a partir da comparação entre a proporções de alunos que fizeram uso de alguma droga nos últimos 12 meses por tipo de droga, área de estudo e total das pesquisas realizadas em 1996 e 2001. (Intervalo de confiança 95\%).}

\begin{tabular}{|c|c|c|c|c|c|c|c|c|}
\hline & & \multicolumn{7}{|c|}{ Uso nos últimos 12 meses } \\
\hline & & \multicolumn{2}{|c|}{1996} & \multicolumn{2}{|r|}{2001} & \multirow{2}{*}{$\begin{array}{l}\text { Diferença } \\
\text { total USP }\end{array}$} & \multicolumn{2}{|c|}{ Intervalo para a diferença } \\
\hline & & total & total USP & total & total USP & & & \\
\hline \multirow[t]{3}{*}{ Maconha } & Humanas & 0,212 & 0,199 & 0,261 & 0,228 & 0,029 & 0,007 & 0,050 \\
\hline & Exatas & 0,157 & & 0,174 & & & & \\
\hline & Biológicas & 0,224 & & 0,198 & & & & \\
\hline \multirow[t]{3}{*}{ Alucinógenos } & Humanas & 0,042 & 0,035 & 0,054 & 0,050 & 0,015 & 0,005 & 0,025 \\
\hline & Exatas & 0,021 & & 0,039 & & & & \\
\hline & Biológicas & 0,032 & & 0,052 & & & & \\
\hline \multirow[t]{3}{*}{ Anfetaminas } & Humanas & 0,030 & 0,027 & 0,057 & 0,053 & 0,026 & 0,018 & 0,035 \\
\hline & Exatas & 0,012 & & 0,034 & & & & \\
\hline & Biológicas & 0,038 & & 0,068 & & & & \\
\hline \multirow[t]{3}{*}{ Inalantes } & Humanas & 0,080 & 0,088 & 0,137 & 0,135 & 0,047 & 0,032 & 0,061 \\
\hline & Exatas & 0,080 & & 0,102 & & & & \\
\hline & Biológicas & 0,125 & & 0,173 & & & & \\
\hline \multirow[t]{3}{*}{ llegais } & Humanas & 0,285 & 0,280 & 0,339 & 0,312 & 0,032 & 0,003 & 0,060 \\
\hline & Exatas & 0,237 & & 0,240 & & & & \\
\hline & Biológicas & 0,329 & & 0,326 & & & & \\
\hline
\end{tabular}




\section{As drogas que apresentaram aumento}

significativo de consumo nos últimos 30 dias foram: maconha, anfetaminas, inalantes e ilegais.

Tabela 36 - Drogas que apresentaram diferença estatisticamente significante a partir da comparação entre a proporções de alunos que fizeram uso de alguma droga nos últimos 30 dias por tipo de droga, área de estudo e total das pesquisas realizadas em 1996 e 2001. (Intervalo de confiança $95 \%$ ).

\begin{tabular}{|c|c|c|c|c|c|c|c|c|}
\hline & & \multicolumn{7}{|c|}{ Uso nos últimos 30 dias } \\
\hline & & \multicolumn{2}{|c|}{1996} & \multicolumn{2}{|c|}{2001} & \multirow{2}{*}{$\begin{array}{l}\text { Diferença } \\
\text { total USP }\end{array}$} & \multicolumn{2}{|c|}{ Intervalo para a diferença } \\
\hline & & total & total USP & total & total USP & & & \\
\hline \multirow[t]{3}{*}{ Maconha } & Humanas & 0,155 & 0,149 & 0,199 & 0,169 & 0,020 & 0,001 & 0,039 \\
\hline & Exatas & 0,126 & & 0,125 & & & & \\
\hline & Biológicas & 0,164 & & 0,137 & & & & \\
\hline \multirow[t]{3}{*}{ Anfetaminas } & Humanas & 0,024 & 0,022 & 0,039 & 0,034 & 0,012 & 0,005 & 0,020 \\
\hline & Exatas & 0,011 & & 0,023 & & & & \\
\hline & Biológicas & 0,030 & & 0,035 & & & & \\
\hline \multirow[t]{3}{*}{ Inalantes } & Humanas & 0,032 & 0,041 & 0,063 & 0,065 & 0,024 & 0,014 & 0,034 \\
\hline & Exatas & 0,042 & & 0,046 & & & & \\
\hline & Biológicas & 0,068 & & 0,097 & & & & \\
\hline \multirow[t]{3}{*}{ Ilegais } & Humanas & 0,170 & 0,173 & 0,240 & 0,218 & 0,045 & 0,018 & 0,070 \\
\hline & Exatas & 0,151 & & 0,162 & & & & \\
\hline & Biológicas & 0,212 & & 0,225 & & & & \\
\hline
\end{tabular}




\section{Tabela 37 - Prevalências do uso de drogas na}

vida, nos últimos 12 meses e nos últimos 30 dias

por alunos universitários da USP e da UNESP.

\begin{tabular}{|c|c|c|c|c|c|c|c|c|c|}
\hline \multirow[t]{2}{*}{ Suhstâncias } & \multicolumn{3}{|c|}{ I Jso na vida (\%) } & \multicolumn{3}{|c|}{ Íltimos 12 meses } & \multicolumn{3}{|c|}{ Íltimos 30 dias (\%) } \\
\hline & Unesp & $\begin{array}{l}\text { Usp- } \\
96\end{array}$ & $\begin{array}{l}\text { Usp- } \\
01\end{array}$ & Unesp & $\begin{array}{l}\text { Usp- } \\
\text { 96- }\end{array}$ & Usp -01 & Unesp & $\begin{array}{l}\text { Usp- } \\
\text { 96 }\end{array}$ & $\begin{array}{l}\text { Usp- } \\
01\end{array}$ \\
\hline ÁLCOOL & 93,5 & 88,6 & 92 & $\mathbf{7 8 , 8}$ & 79,1 & 79,7 & $\mathbf{7 4 , 4}$ & $\mathbf{7 1 , 4}$ & 69,7 \\
\hline Tabaco & 43,1 & 42,9 & 50,6 & 27,8 & 24,0 & 26,3 & 25,2 & 21,0 & 22,6 \\
\hline Maconha & 25,8 & 31,1 & 35,3 & 16,9 & 19,9 & 22,8 & 14,9 & 14,9 & 16,9 \\
\hline Solventes & 26,4 & 18 & 24,6 & 13,6 & 8,8 & 13,5 & 11,3 & 4,1 & 6,5 \\
\hline Anfetaminas & 8,5 & 4,9 & 9,1 & $\mathbf{4 , 4}$ & 2,7 & 5,3 & 4,0 & 2,2 & 3,4 \\
\hline Cocaína & 6,2 & 6,8 & 6,5 & 3,5 & 3,4 & 2,8 & 2,9 & 1,9 & 1,5 \\
\hline Alucinógenos & 6,2 & 6,2 & 11,5 & 3,4 & 3,5 & $\mathbf{5 , 0}$ & 2,7 & 1,9 & 2,5 \\
\hline Sedativos & 3,5 & 5,9 & 7,2 & 1,8 & 2,9 & $\mathbf{3 , 8}$ & 1,8 & 2,6 & 2,4 \\
\hline Anticolinérgicos & 2.1 & 1.1 & 3.0 & 1.2 & 0.5 & 0.8 & 1.2 & 0.6 & 0.4 \\
\hline Anabolizantes & 1,3 & 0,5 & 0,4 & 0,7 & 0,3 & 0,3 & 0,6 & 0,3 & 0,1 \\
\hline Crack & 1,1 & 0,8 & 1,0 & 0,6 & 0,6 & 0,1 & 0,5 & 0,3 & 0,0 \\
\hline Ecstasy & 1,0 & - & 2,3 & 0,6 & - & 1,4 & 0,6 & - & 0,8 \\
\hline
\end{tabular}




\section{Tabela 38 - Comparação entre as pesquisas de}

1996 e 2001 sobre as opiniões sobre uso regular de diversas drogas. (Intervalo de confiança $95 \%)$.

\begin{tabular}{lcccc} 
& $\mathbf{p}^{\boldsymbol{\wedge} \mathbf{1}}-\mathbf{p}^{\wedge \mathbf{2}}$ & $\operatorname{Var}\left(\mathbf{p}^{\wedge}\right)^{\mathbf{1}}+\operatorname{Var}\left(\mathbf{p}^{\wedge}\right)^{\mathbf{2}}$ & inferior & superior \\
\hline ALCOOL & 0,049 & 0,00024 & 0,018 & 0,079 \\
MACONHA & $-0,057$ & 0,00017 & $-0,084$ & $-0,031$ \\
COCAINA & $-0,165$ & $8,75627 \mathrm{E}-05$ & $-0,183$ & $-0,147$ \\
CRACK & $-0,014$ & $2,13524 \mathrm{E}-05$ & $-0,023$ & $-0,005$ \\
TRANQUILIZANTES & 0,0280 & $3,73021 \mathrm{E}-05$ & 0,0161 & 0,040 \\
ANFETAMINAS & $-0,029$ & $4,65433 E-05$ & $-0,042$ & $-0,016$ \\
INALANTES & $-0,015$ & $3,44141 \mathrm{E}-05$ & $-0,026$ & $-0,003$ \\
\hline
\end{tabular}

Tabela 39 - Comparação entre as pesquisas de 1996 e 2001 sobre as opiniões sobre experimentar diversas drogas. (Intervalo de confiança 95\%)

\begin{tabular}{lcccc} 
& $\mathbf{p}^{\wedge 1} \mathbf{-} \mathbf{p}^{\wedge \mathbf{2}}$ & $\operatorname{Var}\left(\mathbf{p}^{\wedge}\right)^{\mathbf{1}}+\operatorname{Var}\left(\mathbf{p}^{\wedge}\right)^{\mathbf{2}}$ & inferior & superior \\
\hline ALCOOL & 0,067 & 0,000164422 & 0,042 & 0,092 \\
MACONHA & 0,023 & 0,000255816 & $-\mathbf{0 , 0 0 7}$ & $\mathbf{0 , 0 5 5}$ \\
COCAINA & $-0,276$ & 0,000177224 & $-0,302$ & $-0,249$ \\
CRACK & $-0,055$ & $7,39407 \mathrm{E}-05$ & $-0,072$ & $-0,038$ \\
TRANQUILIZANTES & 0,175 & 0,000128655 & 0,153 & 0,197 \\
ANFETAMINAS & $-0,076$ & 0,000145193 & $-0,100$ & $-0,052$ \\
INALANTES & $-0,038$ & 0,000153004 & $-0,062$ & $-0,014$ \\
\hline
\end{tabular}




\subsubsection{Modelos de regressão logística}

\subsubsection{Uso corrente de álcool (últimos 30 dias)}

Modelo para Perfil do aluno

- excluídas pelo qui-quadrado: estado civil, atividade remunerada

- excluídas no modelo de logística, nessa ordem: faixa etária, condições de moradia

- mantidas no modelo: sexo, praticar religião

Modelo para Ambiente familiar

- excluídas pelo qui-quadrado: problemas causados pela bebida por algum familiar, pai faz uso freqüente de drogas e mãe faz uso freqüente de drogas

- excluídas no modelo de logística, nessa ordem: escolaridade do pai, escolaridade da mãe, mãe faz uso freqüente de álcool, pai faz uso freqüente de álcool, pais vivem

- mantidas no modelo: renda familiar, irmão faz uso de álcool, irmão faz uso de drogas

Modelo para Curso universitário

- excluídas pelo qui-quadrado: período

- excluídas no modelo de logística, nessa ordem: unidade, ano de ingresso, ano do curso

- mantidas no modelo: área 
- excluídas pelo qui-quadrado: satisfação com a escolha profissional, ano em que pensou em abandonar o curso, desempenho escolar

- excluídas no modelo de logística, nessa ordem: deixa de fazer trabalhos acadêmicos, aprovação no último semestre, pensou em abandonar o curso

- mantidas no modelo: lugares que frequenta na universidade, perspectivas de trabalho e financeiras após formatura, atividade quando falta às aulas

Modelo para Grupo de amigos

- excluídas pelo qui-quadrado: dificuldades em fazer novos amigos, sentir-se rejeitado pelos amigos

- excluídas no modelo de logística, nessa ordem: amigos fazem uso freqüente de álcool

- mantidas no modelo: julgar-se facilmente influenciável pelo amigos, amigos fazem uso freqüente de drogas

Modelo para Lazer

- excluídas pelo qui-quadrado: horas livres nos dias úteis, dedica às atividades tempo satisfatório

- excluídas no modelo de logística, nessa ordem: nenhuma

- mantidas no modelo: horas livres nos fins de semana, atividades nas horas livres

Modelo para Uso pessoal de drogas

- excluídas pelo qui-quadrado: nenhuma

- excluídas no modelo de logística, nessa ordem: nenhuma 
- mantidas no modelo: usou drogas nos últimos 12 meses, usou tabaco nos últimos 12 meses, experimentou drogas antes de entrar na universidade, envolveu-se em acidente de carro após uso de drogas e/ou álcool

Modelo para Atitudes relacionadas às drogas (o que pensa a respeito de uma pessoa que)

- excluídas pelo qui-quadrado: experimentar crack, usar regularmente tranqüilizantes

- excluídas no modelo de logística, nessa ordem: usar regularmente anfetaminas, usar regularmente crack, usar regularmente inalantes, experimenta inalantes, experimentar tranqüilizantes, usar regularmente cocaína

- mantidas no modelo: experimentar álcool, experimentar maconha, experimentar cocaína, experimentar anfetaminas, usar regularmente álcool, usar regularmente maconha

No modelo final, as variáveis foram excluídas na seguinte ordem: perspectivas de trabalho e financeiras após formatura, atividades nas horas livres, o que pensa a respeito de uma pessoa experimentar maconha, o que pensa a respeito de uma pessoa experimentar anfetaminas, praticar religião, sexo, área, irmão faz uso freqüente de drogas, o que pensa a respeito de uma pessoa usar regularmente maconha, lugares que freqüenta na universidade, julgar-se facilmente influenciável pelos amigos, envolveu-se em acidente de carro após uso de drogas e/ou álcool, irmão faz uso freqüente de álcool, horas livres nos fins de semana, o que pensa a respeito de uma pessoa experimentar cocaína. 
Tabela 40 - Modelo de regressão logística final para uso de álcool no último mês.

\begin{tabular}{|c|c|c|c|c|}
\hline Variáveis & $\begin{array}{l}\text { Odds } \\
\text { Ratio }\end{array}$ & $\begin{array}{l}\text { 95\%lC } \\
\text { Inferior }\end{array}$ & $\begin{array}{l}95 \% \text { IC } \\
\text { Super. }\end{array}$ & $\mathbf{p}$ \\
\hline \multicolumn{5}{|c|}{ Renda familiar (em salários mínimos) } \\
\hline 11 to 20 & 1,23 & 0,85 & 1,76 & 0,268 \\
\hline 21 to 30 & 1,54 & 1,06 & 2,24 & 0,025 \\
\hline 31 to 40 & 1,49 & 0,94 & 2,37 & 0,088 \\
\hline 40 or + & 2,00 & 1,29 & 3,08 & 0,002 \\
\hline \multicolumn{5}{|l|}{ Atividades de lazer } \\
\hline Teatro, cinema & 1,70 & 0,73 & 3,99 & 0,221 \\
\hline Estuda em casa & 1,72 & 1,14 & 2,60 & 0,010 \\
\hline Trabalha & 2,21 & 1,32 & 3,69 & 0,003 \\
\hline Dorme ou descança & 2,00 & 1,35 & 2,95 & 0,001 \\
\hline Frequenta DA/CA* & 2,57 & 1,32 & 5,02 & 0,006 \\
\hline \multicolumn{5}{|c|}{ Aprova algúem exp.álcool } \\
\hline & 5,74 & 4,30 & 7,67 & 0,000 \\
\hline \multicolumn{5}{|c|}{ Aprova alguém usar reg. Álcool } \\
\hline & 1,94 & 1,42 & 2,66 & 0,000 \\
\hline \multicolumn{5}{|c|}{ Usou tabaco nos últimos 12 meses } \\
\hline & 2,21 & 1,46 & 3,36 & 0,000 \\
\hline \multicolumn{5}{|c|}{ Experimentou drogas ileg. antes da Univ. } \\
\hline & 1,59 & 1,07 & 2,36 & 0,021 \\
\hline \multicolumn{5}{|c|}{ Amigos usam freq. drogas ilegais } \\
\hline & 1,65 & 1,22 & 2,23 & 0,001 \\
\hline \multicolumn{5}{|c|}{ Usou drogas ilegais nos últimos 12 meses } \\
\hline & 2,86 & 1,92 & 4,27 & 0,000 \\
\hline
\end{tabular}

5.3.7.2 Uso recente de drogas ilegais (últimos 12 meses)

Modelo para Perfil do aluno

- excluídas pelo qui-quadrado: estado civil, condições de moradia, atividade remunerada

- excluídas no modelo de logística, nessa ordem: nenhuma

- mantidas no modelo: sexo, faixa etária, ter religião, praticar religião 
Modelo para Ambiente familiar

- excluídas pelo qui-quadrado: problemas causados pela bebida por algum familiar,pai faz uso freqüente de drogas, mãe faz uso freqüente de drogas

- excluídas no modelo de logística, nessa ordem: escolaridade do pai, escolaridade da mãe,pai faz uso freqüente de álcool, mãe faz uso freqüente de álcool

- mantidas no modelo: renda familiar, pais vivem juntos, irmão faz uso freqüente de álcool, irmão faz uso freqüente de drogas

Modelo para Curso universitário

- excluídas pelo qui-quadrado: ano de ingresso, ano do curso, período

- excluídas no modelo de logística, nessa ordem: unidade

- mantidas no modelo: área

Modelo para Vida acadêmica

- excluídas pelo qui-quadrado: satisfação com a escolha profissional, ano em que pensou em abandonar o curso, perspectivas de trabalho e financeiras após formatura

- excluídas no modelo de logística, nessa ordem: deixa de fazer trabalhos acadêmicos, desempenho escolar

- mantidas no modelo: lugares que freqüenta na universidade, pensou em abandonar o curso, aprovação no último semestre, atividade quando falta às aulas

Modelo para Grupo de amigos

- excluídas pelo qui-quadrado: sentir-se rejeitado pelo amigos 
- excluídas no modelo de logística, nessa ordem: dificuldade em fazer novos amigos, amigos fazem uso freqüente de álcool

- mantidas no modelo: julgar-se facilmente influenciável pelos amigos, amigos fazem uso freqüente de drogas

\section{Modelo para Lazer}

- excluídas pelo qui-quadrado: dedica às atividades tempo satisfatório

- excluídas no modelo de logística, nessa ordem: horas livres nos dias úteis, horas livres nos fins de semana

- mantidas no modelo: atividades nas horas livres

Modelo para Uso pessoal de drogas

- excluídas pelo qui-quadrado: nenhuma

- excluídas no modelo de logística, nessa ordem: nenhuma

- mantidas no modelo: todas

Modelo para Atitudes relacionadas às drogas (o que pensa a respeito de uma pessoa

- excluídas pelo qui-quadrado: nenhuma

- excluídas no modelo de logística, nessa ordem: usar regularmente tranqüilizantes, experimentar tranqüilizantes, usar regularmente crack, usar regularmente anfetaminas, experimenta álcool, usar regularmente álcool, usar regularmente cocaína, experimentar cocaína

- mantidas no modelo: experimentar maconha, experimentar crack, experimentar anfetaminas, experimentar inalantes, usar regularmente maconha, usar regularmente inalantes 
No modelo final, as variáveis foram excluídas na seguinte ordem: pensou em abandonar o curso, irmão faz uso freqüente de álcool, praticar religião, aprovação no último semestre, sexo, julgar-se facilmente influenciável pelos amigos, atividade quando falta às aulas, atividades nas horas livres, ter religião, renda familiar, lugares que freqüenta na universidade, pais vivem, o que pensa a respeito de uma pessoa usar regularmente inalantes, o que pensa a respeito de uma pessoa experimenta crack, o que pensa a respeito de uma pessoa experimentar anfetaminas 
Tabela 41 - Modelo de regressão logística final para o uso de drogas ilegais nos últimos 12 meses.

\begin{tabular}{|c|c|c|c|c|}
\hline Variáveis & $\begin{array}{l}\text { Odds } \\
\text { Ratio }\end{array}$ & $\begin{array}{l}95 \% \text { IC } \\
\text { Inferior }\end{array}$ & $\begin{array}{l}95 \% \text { IC } \\
\text { Super. }\end{array}$ & $\mathbf{p}$ \\
\hline \multicolumn{5}{|l|}{ Área } \\
\hline Humanas & 1,38 & 1,00 & 1,89 & 0,048 \\
\hline Biológicas & 1,38 & 1,01 & 1,89 & 0,046 \\
\hline \multicolumn{5}{|l|}{ Faixa etária } \\
\hline $15-19$ & 2,16 & 1,10 & 4,24 & 0,025 \\
\hline $20-24$ & 1,90 & 1,03 & 3,49 & 0,039 \\
\hline $25-29$ & 1,59 & 0,79 & 3,23 & 0,195 \\
\hline \multicolumn{5}{|c|}{ Aprova algúem exp. maconha } \\
\hline & 1,50 & 1,10 & 2,04 & 0,011 \\
\hline \multicolumn{5}{|c|}{ Aprova alguém exp. inalantes } \\
\hline & 2,40 & 1,71 & 3,37 & 0,000 \\
\hline \multicolumn{5}{|c|}{ Aprova alguém usar reg. maconha } \\
\hline & 2,48 & 1,73 & 3,55 & 0,000 \\
\hline \multicolumn{5}{|c|}{ Usou álcool nos últ. 12 meses } \\
\hline & 2,03 & 1,28 & 3,22 & 0,003 \\
\hline \multicolumn{5}{|c|}{ Usou tabaco nos últ. 12 meses } \\
\hline & 3,05 & 2,30 & 4,05 & 0,000 \\
\hline \multicolumn{5}{|c|}{ Exp. drogas ileg. antes da univ. } \\
\hline & 3,51 & 2,64 & 4,66 & 0,000 \\
\hline \multicolumn{5}{|c|}{ Acid. carro após uso drogas/álcool } \\
\hline & 3,19 & 1,47 & 6,90 & 0,003 \\
\hline \multicolumn{5}{|c|}{ Irmão faz uso freq. drogas ilegais } \\
\hline & 2,58 & 1,43 & 4,68 & 0,002 \\
\hline \multicolumn{5}{|c|}{ Amigos fazem uso freq. drogas ilegais } \\
\hline & 2,00 & 1,54 & 2,60 & 0,000 \\
\hline
\end{tabular}




\section{DISCUSSÃO DOS RESULTADOS.}

O GREA, através do apoio da FAPESP e do estabelecimento de outras parcerias, tem contribuído para tornar mais clara a visão do uso de drogas entre estudantes universitários da cidade e do estado de São Paulo (ANDRADE et al., 1995, 1996, 1997). Esta pesquisa visou contribuir para a complementação deste quadro através do levantamento de dados atuais sobre o uso de drogas entre parcela importante de estudantes universitários da cidade de São Paulo.

O questionário utilizado nesta pesquisa foi estruturado de modo a levantar o uso de substâncias psicoativas e outros aspectos da vida dos estudantes que, tradicionalmente vêm apresentando, associação com este uso. A partir dos dados coletados através desta pesquisa foi possível avaliar o padrão de uso de álcool e outras drogas pelos alunos de graduação da USP, no Campus São Paulo, comparar o padrão de uso e das atitudes frente ao uso de álcool e outras drogas com o último levantamento realizado em 1996 (ANDRADE et al., 1997), identificar os grupos específicos mais expostos ao problema e as drogas mais utilizadas e fornecer subsídios para futuras ações preventivas com esta população. Estas informações foram apresentadas em blocos de acordo com o tema específico a que se referiam (vide item resultados desta Tese).

Nesta discussão pretende-se refletir sobre seis blocos de variáveis que foram também objeto da análise estatística: perfil sócio-demográfico; opinião e conseqüências do uso de drogas; comparação do uso de drogas entre os anos de 1996 e 2001; comparação do uso de drogas entre os estudantes das áreas de Humanas, Exatas e Biológicas; comparação do uso de drogas entre estudantes do sexo masculino e feminino e variáveis ambientais do modelo 
final de regressão logística para o uso corrente de álcool. A discussão do modelo de regressão logística final para o uso recente de drogas ilegais será realizada dentro destes mesmos blocos.

$\mathrm{O}$ aumento de consumo de diversas substâncias psicoativas e as relativamente altas prevalências encontradas fazem com que uma preocupação quanto às conseqüências deste uso surja como uma questão legítima. O paradigma metodológico que orientou esta pesquisa parte do pressuposto de que o risco a ser inferido dos cruzamentos associativos das variáveis dependentes e independentes conduzirá aos fatores que merecem uma maior atenção ao se pensar a atuação preventiva quanto ao uso ou as conseqüências dele entre jovens universitários. Além disso, a pesquisa forneceu um retrato deste uso, as drogas mais utilizadas e seus padrões de uso, dentre outras informações. Estas são as possibilidades e os limites deste trabalho. Nesta discussão, pretende-se também incluir as limitações desta pesquisa, pois elas são os desafios dos cientistas, os pontos que precisam ser desenvolvidos de modo a aprimorar os métodos de investigação científica e promover uma melhor sintonia entre a reflexão acadêmica e a práxis em saúde coletiva.

\subsection{Dados sócio-demográficos}

A maior parte dos questionários foi respondida por alunos que ingressaram na USP entre os anos de 1997 e 2000, ou seja, cursando entre o primeiro e o quarto ano de algum dos 21 cursos de graduação investigados. $57,78 \%$ dos respondentes eram do sexo masculino e $42,22 \%$ do sexo feminino, o que aproximadamente corresponde à proporção entre homens e mulheres da população de estudantes de graduação da USP, 
respectivamente $57.30 \%$ e $42.69 \%$, segundo o Anuário Estatístico da USP (2000).

O principal problema encontrado para obter-se uma maior proporção de respostas aos questionários foi a dificuldade em contatar os alunos. Esta dificuldade, que acabou por exigir um longo período de coleta de dados para ser contornada, impediu a realização da abordagem de uma amostragem dos alunos não-respondentes, como inicialmente previsto. O tempo e os recursos tornaram-se insuficientes para a implementação desta fase da pesquisa inicialmente planejada. A importância deste passo residia na possibilidade de investigar se o perfil dos $16,39 \%$ dos alunos que não participaram da pesquisa diferiria significativamente do perfil de quem participou.

A maior parte da nossa amostra estava cursando o período diurno (matutino e integral) e pertencia à faixa etária entre 20 e 24 anos. A variável idade é de especial importância, pois apresenta associação com os tipos e as formas do uso de drogas e é uma das mais importantes na descrição do fenômeno. Kandel e Logan (1984), em seu clássico estudo de coorte de estudantes de Nova York encontraram este período de vida como o de maior risco para o consumo de álcool, maconha e cigarros. Shall et al. (1992) citam Clarck e Midanik (1982), que demonstraram que este período de desenvolvimento é o de maior prevalência de consumo pesado de bebidas alcoólicas.

Kerr-Correa et al. (2001) encontrou que entre estudantes universitários e colegiais da UNESP, o uso de maconha atinge seus picos de prevalência entre os 17 e 28 anos, diferentemente do álcool e do tabaco. Dados semelhantes aos encontrados nesta pesquisa. As faixas etárias que permanceram significativas para um maior risco de uso de drogas ilegais nos últimos 12 meses foram as entre 15 e 29 anos. Strote et al. (2002), analisando os dados obtidos através de pesquisas com amostras nacionais de estudantes de graduação de 140 universidades americanas, 
concluiu que, para o uso de ecstasy, estudantes com mais de 24 anos, não apresentaram aumento de consumo desta substância como ocorreu entre estudantes mais jovens. Estes estudos mostraram que após este período observa-se com mais freqüência uma diminuição destas prevalências. Para o caso da maconha Chen e Kandel (1998), observaram que variáveis sociais, fenomenológicas, assim como o sexo e a saúde, são responsáveis pela redução e abandono do consumo de maconha em momentos posteriores da vida.

No entanto, para o uso da cocaína, este período se alonga mais, nesta faixa etária, dos 20 aos 24 anos, não se observa o uso mais freqüente desta substância, uma vez que prevalências maiores de uso de cocaína são observadas em períodos posteriores da vida (KANDEL AND LOGAN, 1984). No I Levantamento Domiciliar sobre o Uso de Drogas Psicotrópicas no Brasil (CARLINI et. al., 2001), nota-se que, para o álcool, ocorre fenômeno semelhante, os picos de uso regular desta substância ocorrem na faixa etária superior aos 35 anos. O período de vida dos indivíduos participantes desta pesquisa pode, portanto, ser considerado intermediário para um uso mais intenso de álcool e cocaína. Por essas razões este período de vida é extremamente importante para a prevenção do abuso destas substâncias em fases posteriores da vida. Apesar de outros fatores se associarem ao longo da vida com o uso de drogas e influenciarem seu aumento, manutenção ou diminuição, o período universitário propicia importante oportunidade para a adoção de comportamentos mais saudáveis e protetores de futuras conseqüências adversas decorrentes do abuso destas substâncias.

Quanto aos aspectos familiares, a maioria possuía pai e mãe com diploma de curso superior e vivendo juntos. Apesar de a renda familiar ser bem distribuída entre as diversas faixas investigadas, a maior parte das famílias dos alunos concentrou-se nas faixas entre 11 e 30 salários mínimos. Um dado interessante foi a parcela de estudantes com renda familiar acima 
de 40 salários mínimos e abaixo de 10 salários mínimos, respectivamente $20,42 \%$ e $17,88 \%$ da amostra. Estes dados são importantes na medida em que revelam que, na USP, estão representados principalmente indivíduos provenientes das classes média e média alta, pois os dados do Censo 2000 (IBGE, 2002) indicam que apenas $8.2 \%$ da população brasileira recebem mais do que 10 salários mínimos mensais. Observando-se o critério escolaridade, há o predomínio de alunos cujos pais possuem nível superior. Segundo o Censo 2000, apenas $4.1 \%$ da população possui curso superior completo. Um aspecto relevante deste estudo está no fato de os resultados serem válidos para os alunos da USP e indicarem como age e pensa importante parcela de jovens de classe média e média superior da nossa sociedade. 


\subsection{Dados sobre opinião quanto ao uso de drogas e suas conseqüências}

Os maiores índices de aprovação para experimentar drogas são para as drogas lícitas (álcool e tabaco) e para a maconha. Os maiores índices de desaprovação referem-se ao crack e a cocaína. Os maiores índices de aprovação para o uso regular de drogas referem-se ao álcool, tabaco e maconha. E os maiores índices de desaprovação referem-se às drogas ilícitas exceto maconha. Esses dados são extremamente importantes. Queiroz (2000), encontrou correlação positiva entre aprovar o uso experimental e regular de maconha e usar algum tipo de droga ilícita. Calculou respectivamente Odds Ratio de 2,7 e 3,2 para quem aprovava o uso experimental e regular de maconha. Nesta pesquisa, para estas mesmas variáveis, foram calculadas Odds Ratio de 1,5 e 2,48. Para os alunos que apresentaram opinião favorável de experimentar inalantes a Odds Ratio calculado foi de 2,4 .

Comparando as pesquisas de 1996 e 2001 quanto a opinião de usar regularmente certa substância psicoativa, observa-se, na tabela 38, que em 1996 havia mais aprovações quanto ao uso regular de álcool e tranqüilizantes; enquanto que em 2001 havia mais aprovações quanto ao uso regular de maconha, cocaína, crack, anfetaminas e inalantes. Estes dados são extremamente intrigantes, pois indicam uma mudança de opinião no sentido de uma maior liberalidade quanto ao uso de substâncias ilícitas e traz consigo necessariamente o questionamento de que fenômeno é este que se observa entre os jovens universitários. Em conjunto com os dados indicativos de aumento de consumo, está-se percebendo um quadro realmente preocupante, formado por este par de variáveis: aumento de consumo e aumento da opinião favorável quanto ao uso de substâncias psicoativas ilícitas. 
Um terceiro conjunto de variáveis que associada a estas duas, poderia esclarecer ainda mais o sentido destes dados, são as percepções das conseqüências adversas decorrentes do uso freqüente de drogas. Na tabela 27, pode-se observar que a maioria dos estudantes que faz uso freqüente de drogas acha que este uso não interfere em nenhuma das esferas das suas vidas, 6,66\%. Dos que percebem algum tipo de interferência, as de maior prevalência são no sono (5,39\%), nos estudos (5,13\%) e na alimentação (4,13\%). Yu (2001), investigando as conseqüências negativas do uso de álcool entre estudantes universitários, demonstrou que estas conseqüências são diretamente associadas à intensidade desse uso e se estende aos outros estudantes, companheiros de universidade. Outras conseqüências importantes podem ser levantadas, como as da ordem das relações entre os estudantes o que inclui violência física e sexual. A hipótese deste autor é que as conseqüências negativas podem se melhor compreendidas como um fenômeno decorrente de um processo grupal do que circunstâncias individuais. Uma futura pesquisa poderia detalhar os possíveis danos em cada uma destas esferas da vida apontadas como prejudicadas. Pretende-se, brevemente, testar a hipótese de associação entre o relato de danos e o consumo freqüente de alguma substância psicoativa. Seria importante também saber mais sobre as variadas formas de consumo, pois os danos podem decorrer não só da freqüência mas muitas vezes da forma e situações de uso. Entre as conseqüências decorrentes do abuso de álcool, Lanier et al. (2001), identificou perda de aulas, dirigir sob o efeito da bebida e fazer alguma coisa de que depois se arrependa, como esferas de prevalência expressiva de danos entre estudantes universitários. No modelo final de regressão logística para o uso recente de drogas ilegais, ter se envolvido em algum acidente de carro após o uso de drogas/álcool demonstrou ser um fator de risco com Odds Ratio de 3.19 e $p=0,003$. 
Quanto aos motivos alegados para o uso de drogas, Lanier et al. (2001), estudaram a associação entre a busca de sensação de bem estar e o uso de drogas. Descobriram que o índice de estresse está associado ao uso de álcool e drogas, reforçando a hipótese de que este uso muitas vezes tem como finalidade a busca de uma sensação bem-estar geral. Outro dado interessante é o de que alunos que participam de atividades esportivas tendem a reduzir seus níveis de estresse de outras formas que não o uso de drogas, reduzindo, portanto seu consumo. Como os dados desta pesquisa revelam que uma das principais áreas atingidas pelo uso de drogas é a da prática esportiva, parece mesmo existir uma associação entre estas duas variáveis. Estes autores citam Perkins (1999), que encontrou resultado semelhante: o uso de álcool para a redução do stress foi o principal motivo para a utilização desta substância entre estudantes de graduação.

No entanto, nesta pesquisa, verificou-se que a maioria dos estudantes que já experimentou alguma droga ilícita, o fez por curiosidade ou por diversão e prazer. Dos que fazem uso freqüente de drogas, a maior parte 0 faz para "curtir" seus efeitos. A redução do estresse aparece como o segundo motivo mais alegado para o consumo freqüente de drogas ilícitas. Novos estudos necessitam ser feitos para se entender melhor estas diferenças. Mas um detalhamento destas variáveis poderia ser de utilidade para compreenderse melhor quais as sensações buscadas no uso de determinada substância e se indireta ou diretamente não estariam associadas a busca de uma sensação de bem estar para inclusive aliviar o estresse da situação acadêmica.

$\mathrm{Na}$ tabela 39, observa-se a mesma comparação para a opinião sobre a experimentação de alguma substância psicoativa. Em 1996, havia mais aprovações quanto ao ato de experimentar as substâncias álcool e tranqüilizantes. Em 2001, havia mais aprovações quanto ao ato de experimentar as substancias cocaína, crack, 
anfetaminas e inalantes. Não houve diferença entre as opiniões quanto a experimentar maconha. Não deixa de ser interessante observar a aparente contradição que estes dados revelam. Apesar do aumento da aprovação do uso experimental e regular de crack e cocaína, não foi encontrado aumento significativo do uso destas substâncias entre os anos de 1996 e 2001.

Os quadros comparativos revelam aumento na aprovação de várias drogas. Como Queiroz demonstrou em seu estudo, há associação da opinião favorável ao uso de drogas com seu efetivo uso (QUEIROZ, 2000). Este dado em parte corrobora os resultados que demonstraram aumento do consumo de diversas substâncias. No entanto, não ajuda a compreender a estabilização do consumo encontrada com relação ao crack e à cocaína, do que se encontrou aumento de aprovação entre os dois períodos. Outros estudos são necessários para esclarecer esta questão. Outra hipótese possível é que tenha havido uma sub-notificação do uso de cocaína e crack. Comparando os resultados desta pesquisa para a variável - consumo nos últimos 30 dias de cocaína - com aqueles obtidos por Kerr-Corrêa et al. (2001), entre os estudantes da Universidade do Estado de São Paulo - UNESP. Obsena-se uma prevalência maior entre os alunos da UNESP: $2,9 \%$ contra 1,23\% para uso de cocaína e 0,5\% contra 0,18\% para o uso de crack.

\subsection{Dados sobre o consumo de drogas e comparações entre 1996 e 2001}

A maior parte dos estudantes que usaram drogas ilícitas antes de entrar na USP, usaram, em ordem da maior para a menor prevalência, maconha, inalantes, alucinógenos e cocaína. Esta é uma outra variável que mostrou associação com o uso atual de alguma droga ilícita. Segundo Queiroz (2000), quem utilizou drogas antes de entrar na USP, apresentou Odds Ratio 5.0 para o uso nos últimos 12 meses de qualquer droga ilícita, 
com relação a quem não usou. Nesta pesquisa, para esta mesma variável foi calculada Odds Ratio de 3,51. Estes dados podem ser colocados em conjunto com as varáveis opinião favorável sobre o uso de drogas ilegais e o uso frequente de drogas ilegais por irmãos e amigos como fatores. Estas variáveis, se presentes, aumentam os riscos para o uso corrente de álcool e recente de drogas ilegais e paracem formar um conjunto extremamente importante de fatores. Este conjunto de variáveis constitui as normas sociais compartilhadas sobre o uso de substâncias psicoativas entre os estudantes da Universidade de São Paulo em maior situação de risco para o abuso de álcool e drogas ilegais.

Outro aspecto que merece uma análise mais aprofundada é que a cocaína é apontada como a quarta droga ilícita mais utilizada antes de entrar na universidade. Enquanto que as prevalências atuais de uso de cocaína são menores do que as prevalências de uso de anfetaminas e tranqüilizantes nos três momentos investigados, ocupando a sexta posição. Mais uma vez, os fatores faixa etária e características sociais parecem influenciar a transformação do padrão de uso no tempo. A ordem das prevalências atuais das drogas ilícitas utilizadas pelo estudante de Graduação USP é muito semelhante a ordem encontrada por Galduróz et al. (1997), entre estudantes de primeiro e segundo graus, que é: solventes, maconha, ansiolíticos, anfetamínicos e cocaína. Este estudo foi realizado com estudantes pertencentes a faixa etária em que se deu o uso anterior ao ingresso na USP. O que aconteceu neste período de tempo que fez com que os tranqüilizantes e as anfetaminas passassem a ter uso mais prevalente do que o de cocaína. É necessário enfatizar que os estudantes da USP procedem predominantemente de escolas privadas enquanto que o estudo de Galduróz et al. (1997), foi realizado com estudantes de escolas públicas. Talvez o 
maior poder aquisitivo maior destes jovens e seus valores culturais tornaramnos mais vulneráveis ao uso da cocaína quando eram mais jovens. Outro fator que pode ser importante é que tranqüilizantes e anfetaminas são as drogas mais utilizadas por estudantes do sexo feminino e é possível inferir que a vida universitária e idade atuem vulnerabilizando, principalmente as mulheres, para o uso destas drogas.

Comparando os dados desta pesquisa com os da pesquisa de 1996, pode-se observar (Tabelas 34, 35 e 36) que, nestes últimos 6 anos, houve um aumento significativo de consumo. a) na vida: álcool, tabaco, maconha, alucinógenos, anfetaminas, anti-colinérgicos, inalantes, barbitúricos e ilegais; b) nos últimos 12 meses: maconha, alucinógenos, anfetaminas, inalantes e ilegais; c) nos últimos $\mathbf{3 0}$ dias: maconha, anfetaminas, inalantes e ilegais.

Os resultados obtidos através da pesquisa "Álcool e Drogas: Pesquisa sobre Atitudes e Uso em Alunos da Universidade de São Paulo - Campus São Paulo" (1995-96), indicavam as prevalências de 38,1\% de uso na vida, 26,3\% nos últimos 12 meses e 18,9\% nos últimos 30 dias de drogas ilícitas na vida (ANDRADE et al., 1997), resultados superiores aos encontrados por Galduróz et al. (1997), com estudantes de $1^{\circ}$ e $2^{\circ}$ graus e superiores também aos de MAGALHÃES et al. (1991), com estudantes universitários da cidade de São Paulo.

Outro dado relevante, é que os diversos subgrupos em que a amostra foi dividida (áreas de estudo; sexo e período de curso) apresentavam padrões diferentes de consumo de drogas. Identificou-se que as drogas lícitas - álcool e tabaco - são as mais consumidas, enquanto que o uso de drogas ilícitas é maior entre os alunos da área de Ciências Humanas e maior ainda entre os que moram sem a família. È importante não esquecer também que a relação entre o uso de drogas lícitas e ilícitas. O modelos finais de regressão logística para o uso corrente de álcool e recente de drogas ilegais apresentam claramente esta relação. O uso de drogas 
ilegais esta relacionado a um maior risco para o uso de álcool e o uso de tabaco e álcool esta relacionado a uma maior risco para o uso de drogas ilegais.

Os parâmetros disponíveis para a comparação dos dados desta pesquisa e para a compreensão do sentido destes aumentos das prevalências, provêm dos dados relativos à evolução do consumo de drogas em termos da população em geral e em populações específicas semelhantes no mundo e no Brasil.

O estudo de Galduróz et al. (1997), demonstrou algumas tendências de aumento de uso de drogas nos últimos 10 anos entre os estudantes de primeiro e segundo graus brasileiros. Na cidade de São Paulo, este aumento foi observado para o uso na vida de maconha, cocaína e tabaco, aumento de uso freqüente de maconha, cocaína e álcool e aumento de uso pesado de maconha, cocaína e álcool.

Estes resultados parecem estar em concordância com as tendências mundiais de crescimento do consumo destas substâncias na população em geral (GLOBAL ILLICIT DRUG TRENDS, 2002), com o agravante de que neste estudo, outras drogas também apresentaram um aumento. A boa notícia fica por conta da cocaína cujas prevalências entre alunos da USP permaneceu estável nestes últimos 6 anos.

Já a pesquisa MONITORING THE FUTURE (2001), que vem sendo realizada há 27 anos com uma amostra nacional de estudantes dos $8^{\circ}, 10^{\circ}$ e $12^{\circ}$ anos de estudo nos Estados Unidos, demonstrou que, há 4 anos, observa-se uma estabilização nos índices de uso de drogas ilícitas e um aumento na desaprovação da experimentação de maconha. Dados que podem representar o início de um movimento de diminuição de consumo de certas drogas.

A maconha aparece como a droga ilícita de maior uso na vida, no ano e nos últimos $\mathbf{3 0}$ dias entre os alunos da USP, dados coincidentes com os de estudantes brasileiros e americanos (GALDUROZ et al., 1997, 
MONITORING THE FUTURE, 2001), e outras populações universitárias (MAGALHÃES et al. 1991, KERR-CORREA et al., 2001, WEBB, 1997, MOURÃO, 2002) em muitos países do mundo (BAUMAN, 1999). É também a droga de maior aprovação para uso regular e experimental dentro da Universidade de São Paulo, o que demonstrou ser um fator de risco para o uso de outras substâncias drogas ilícitas ( QUEIROZ, 2000).

Quanto à cocaína, tanto os dados do IV Levantamento sobre o Uso de Drogas entre Estudantes de $1^{\circ}$ e $2^{\circ}$ graus em 10 Capitais Brasileiras (GALDUROZ et al, 1997) quanto os dados mundiais (GLOBAL ILLICIT DRUG TRENDS, 2002) apontam para um crescimento de seu uso. Já nos EUA o estudo MONITORING THE FUTURE (2001) detectou uma redução do uso de cocaína e crack entre os anos de 2000 e 2001. Na opinião do estudante da USP, a cocaína e crack foram as drogas que apresentaram maior desaprovação (QUEIROZ, 2000), o que pode explicar a estabilização da prevalência de seu uso. No entanto, como já discutido anteriormente, esta pesquisa indicou um aumento dessa aprovação com relação à de 1996. Talvez se esteja presenciando uma mudança lenta de opinião do estudante universitário ainda não refletida pelos dados epidemiológicos, mas já indicada na prevalência de uso numa população imediatamente mais nova, os estudantes de primeiro e segundo graus. Um dado preocupante é que a cocaína é o segundo principal motivo para a procura de tratamento para a dependência de drogas entre estudantes da USP (PRODUSP, 2003), ou seja, apesar de seu consumo não atingir alta prevalência e permanecer estabilizado nestes últimos 6 anos, induz a padrões de uso disfuncionais e geradores de grandes danos. É um outro fator que merece uma investigação mais aprofundada. 
Foram incluídas, neste segundo questionário, questões sobre o uso do ecstasy, que tem apresentado aumento entre estudantes americanos (MONITORING THE FUTURE, 2001) e em países da Europa e em desenvolvimento (GLOBAL ILLICIT DRUG TRENDS, 2002). Foram encontradas prevalências de 2,3\% para uso na vida, 1,4\% nos últimos 12 meses e $0,8 \%$ nos últimos $\mathbf{3 0}$ dias para esta droga, dados que indicam o seu uso entre os estudantes da USP supera o de outras drogas mais conhecidas e há mais tempo no mercado, como crack, anticolinérgicos e opiáceos. Dados como estes revelam um perfil epidemiológico muito específico, cujo fator classe social parece ser importante na determinação de quais drogas são mais aprovadas e utilizadas. Ao contrário, drogas como crack e anticolinérgicos, são mais prevalentes em populações mais vulneráveis, como jovens em situação de rua (NOTO et al, 1997) ou internos na FEBEM - Fundação do Bem Estar do Menor do Estado de São Paulo (SILVA, 1997).

Os inalantes e as anfetaminas apresentaram aumento nos três momentos de consumo levantados - na vida, nos últimos 12 meses e nos últimos $\mathbf{3 0}$ dias. Enquanto as anfetaminas têm tido seu consumo aumentado também em outros países do mundo (GLOBAL ILLICIT DRUG TRENDS, 2002), os inalantes parecem ser uma droga consumida em altas prevalências principalmente no Brasil.

$\mathrm{Na}$ tabela 37 , pode-se observar a comparação das prevalências dos usos de diversas drogas entre os estudantes da USP e da UNESP, que constituem populações semelhantes em diversos aspectos. Nota-se que as prevalências de diversas drogas tendem a ser parecidas, embora algumas diferenças também sejam observadas. Tanto as tendências convergentes 
quanto as diferenças demandam uma análise estatística mais apurada para determinar sua significância.

\subsection{Comparações do uso de drogas entre alunos das três áreas de estudo}

Os resultados encontrados (itens 5.3.1, 5.3.2 e 5.3.3 dos resultados) indicam que os alunos das três áreas de estudo fazem consumo de todas as drogas, mas que, em temos gerais, os alunos de Exatas tendem a fazer um uso significativamente menor do que os de Biológicas e Humanas. Os alunos da área de Humanas continuam a ser os que apresentam maiores prevalências de uso de drogas lícitas e ilícitas, como observado no estudo realizado por Andrade et al. (1997), em 1996. Kerr-Correa et al. (2000), encontrou estes mesmos resultados para a área de Biológicas e não a de Humanas, que supera a de Biológicas quando excluídas a maconha e os inalantes. Esta divisão por áreas é raramente encontrada em trabalhos epidemiológicos com universitários, que em geral utilizam como unidade amostral as faculdades e não as áreas. Nesta outra linha de pesquisa, dados aparentemente semelhantes foram encontrados entre universitários britânicos (WEBB, 1997): os mais baixos índices de uso de tabaco, álcool e drogas ilícitas foram encontrados entre os estudantes de engenharia.

\subsection{Comparações do uso de drogas entre alunos do sexo masculino e feminino}

Quanto ao sexo, as prevalências entre homens e mulheres são iguais para várias drogas, no entanto, os homens consomem mais do que mulheres as seguintes drogas: álcool, inalantes, anabolizantes, crack, cocaína, alucinógenos e maconha. As mulheres consomem mais que os homens as anfetaminas, os tranqüilizantes e os opiáceos, ou seja, substâncias ingeridas como componentes de medicamentos. Esta 
diferença determinada pela diferença de gênero vem sendo observada em praticamente todos os estudos epidemiológicos em todos os países do mundo (WEBB, 1997, BAUMAN, 1999, MONITORING THE FUTURE, 2001, GLOBAL ILLICIT DRUG TRENDS, 2002, CARLINI et al, 2002), apesar de essas mesmas pesquisas informarem que estas diferenças de consumo entre homens e mulheres tendem a se reduzir. Não deixa de ser interessante, no entanto, os dados encontrados por Carlini et al. (2002), que indicam que as mulheres brasileiras consomem mais benzodiazepínicos, estimulantes, orexígenos, codeína, opiáceos, barbitúricos do que os homens. Corroborando estes dados, entre estudantes universitários da UNESP, Kerr-Correa et al. (2000), encontrou prevalências maiores para as mulheres do que para os homens para analgésicos e anfetaminas.

Alguns pesquisadores têm optado por controlar mais precisamente os efeitos diferenciados do consumo de determinada quantidade de álcool por homens e mulheres utilizando a informação sobre o peso corporal (SCHALL, KEMENY e MALTZMAN, 1992). Mesmo assim as diferenças associadas ao gênero permanecem importantes, mas parecem variar segundo a raça. "Estudantes latinos apresentaram as maiores diferenças de uso de álcool entre homens e mulheres do que estudantes brancos. Todos os estudantes latinos de sexo masculino bebiam contra 88,4\% dos estudantes brancos" (SCHALL, KEMENY e MALTZMAN, 1992). Outros estudos mostraram que diferenças de gênero são importantes para explicar não apenas a etiologia, mas também as conseqüências do uso de álcool (NEWCOMB, 1997). Wechsler et al. (1999), investigando o consumo excessivo de álcool entre estudantes de 140 universidades dos EUA em 1993 (pesquisa CAS College Alcohol Study - Escola de Saúde Pública de Harvard), encontraram que homens tendem a usar excessivamente álcool com mais freqüência do que as mulheres e listaram algumas das conseqüências adversas desta forma de uso: falta à aulas, quedas, esquecimento, danos à propriedade, manter relações sexuais sem 
proteção, envolvimento em brigas, etc (WECHSLER et al., 1999). Estes tipos de conseqüências são importantes para pensar a redução de danos decorrentes do uso de álcool. Apesar das mulheres usarem menos álcool e com menos freqüência, observa-se uma tendência de aproximação aos padrões masculinos. Principalmente nas conseqüências as semelhanças são importantes, já que muitas vezes com menos quantidades de álcool ingerido as conseqüências para as mulheres já são adversas. Estes mesmos autores concluem: "para a maioria dos problemas observados as evidências sugerem que mulheres que bebem cinco ou mais doses apresentam maior probabilidade de apresentar alguma destas conseqüências do que homens que bebem a mesma quantidade" (WECHSLER ET AL., 1995).

Uma outra forma de pensar estas diferenças entre as drogas de uso entre homens e mulheres é tentar entender a maior prevalência de uso de medicamentos por estudantes do sexo feminino do que por do sexo masculino. Duas questões são importantes de serem pensadas. A primeira é o fato de que apesar de serem substâncias psicoativas com potencial de abuso, os medicamentos, principalmente as anfetaminas, tranquilizantes e opiáceos investigados nesta pesquisa, pressupoem uma dinâmica de iniciação, aquisição e uso bem diversa das chamadas drogas ilegais. A segunda é o porque parece mais atrativo para as mulheres fazerem uso destas substâncias do que para os homens.

Alguns estudos podem ajudar a esclarecer estes dois pontos que estão interrelacionados. Kauffman, Silver e Poulin (1997) estudando as diferenças de atitude entre mulheres e homens com relação ao uso e abuso de drogas enfatizam que o estigma social com relação ao abuso de drogas pelas mulheres pode ser um fator importante para que estas prefiram fazer uso de substâncias mais "socialmente aceitas" como é o caso dos medicamentos. Segundo Simoni-Wastila (2000) as mulheres por suas características de gênero possuem uma maneira diferente de lidar e expressar ansiedade e streess, buscar tratamento médico e perceber suas 
doenças. Ao mesmo tempo os médicos tendem a tratar diferentemente as mulheres do que os homens. Estes fatores parecem contribuir para uma prescrição mais fácil de alguns tipos de medicamentos para as mulheres e em parte é responsável por uma maior exposição destas a iniciação do seu uso. Esta autora utilizou os dados da pesquisa nacional sobre gastos com tratamento médico realizada em 1987 nos EUA (1987 National Medical Expenditures Survey) e através da análise de regressão logística estimou as probabilidades de abuso de substâncias psicoativas com prescrição médica. As mulheres reportam mais freqüentemente distúrbios mentais e físicos e tendem a usar mais medicamentos em geral do que os homens (SimoniWastila, 2000). Com relação as medicações psicoativas, os opióides e os anxiolíticos foram os que as mulheres apresentaram signifacativamente maior risco de uso do que os homens (Simoni-Wastila, 2000).

Quanto ao período, as prevalências do diurno e do noturno são semelhantes para a maioria das drogas. Percebe-se, no entanto, que os alunos do diurno usam mais inalantes, crack e opiáceos e os do noturno fazem mais uso de cocaína e maconha. No modelo multivariado criado por Queiroz et al. (2000), o período não demonstrou possuir associação estatisticamente significativa com o uso de droga.

6.6 Variáveis ambientais dos modelos de regressão logística para o uso corrente de álcool

Um possível modelo teórico que pode ser utilizado para compreender o conjunto de variáveis (fatores familiares, grupo de amigos, locais que freqüenta dentro e fora da universidade) que compoem o modelo de regressão logística é a teoria das redes sociais (BERKMAN e GLASS, 2000). De acordo com esta abordagem teórica, o uso de álcool e drogas por estudantes universitários pode ser visto como um fenômeno de grupo onde o conjunto de fatores pessoal, ambiental e estrutural torna esta população mais 
exposta ou menos exposta ao risco de usar drogas e suas conseqüências. Para se compreender como estes fatores estão influenciando o uso corrente de álcool destes estudantes é necessário entender os mecanismos psicossociais em ação e a relação destes estudantes com suas redes sociais. "O poder da teoria das redes sociais baseia-se na hipótese testável de que a estrutura da rede social por si só é amplamente responsável por determinar os comportamentos e as atitudes individuais moldando o fluxo de recursos que determinam as oportunidades e os constrangimentos para a expressão de certo comportamento" (BERKMAN e GLASS, 2000). Esta ação das redes sociais se realiza através dos seguintes mecanismos: apoio e sustentação social (emocional, instrumental, avaliação e informação), influência social (normas, regras, valores culturais), participação e engajamento em atividades sociais e acesso a recursos materiais, educacionais, de saúde e de assistência social.

No modelo final de regressão logística para o uso corrente de álcool e também nos modelos ambiente familiar, grupo de amigos, vida acadêmica e atividades nas horas livres, mostraram algumas variáveis relacionadas a um consumo mais freqüente de álcool. Destacaremos três delas para discussão: ambiente familiar, influência dos amigos e estilo de vida. Estes fatores estão presentes nas interações sociais dos estudantes e podem ser vistos como importantes mecanismos na determinação do que é considerado aceitável e valorizado socialmente em termos do comportamento do uso de álcool.

Investigando a influência dos fatores familiares com relação ao abuso e dependência de álcool. Patton (1995) cita Cloninger et al. (1988) "Fatores genéticos são operativos em pelo menos uma forma de abuso de álcool, mas eles nunca são os únicos mecanismos em ação”. Este tipo de afirmação está de acordo com a visão geral acerca da etiologia da dependência de drogas, 
que enfatiza o caráter multifatorial da gênese deste tipo de desordem. No entanto, parece não haver dúvidas de que a família exerce principalmente dois tipos de influência sobre seus membros com relação a dependência ou mesmo o uso de álcool: genética e psicossocial. Patton, citando novamente Cloninger et al. (1981,) afirma: "O alcoolismo tipo II, ou o que possui o padrão de transmissão limitado aos filhos de sexo masculino, é responsável por $25 \%$ dos casos de alcoolismo entre homens e é fortemente relacionado a fatores genéticos". Aquele mesmo autor cita Sher (1991) que descreve que "pelo menos $25 \%$ dos alcoolistas possuem pais alcoolistas e $5 \%$ mães alcoolistas. Se um membro da família é alcoolista há $82 \%$ de chance de haver um outro alcoolista nesta mesma família".

Sobre os fatores psicossociais Patton (1995) afirma: "viver em uma residência onde há um alto nível de conflito entre os membros da família parece aumentar o risco para o uso álcool. O grau de conflito parece ser mais importante do que a estrutura familiar". A qualidade do relacionamento familiar representada pelo estilo de comunicação entre seus membros e pela habilidade de resolver os problemas familiares são fatores relacionados à etiologia do abuso de álcool. Patton (1995) sugere que "o uso de drogas por um adulto que tenha importante influencia sobre um adolescente é um potente fator de risco para o uso de drogas por este adolescente". Os resultados de sua revisão mostram que "adolescentes que dizem ter presenciado o uso de drogas por algum adulto importante para eles apresentam mais chances de vir a experimentar drogas". A presente pesquisa mostra que os estudantes que fazem uso corrente de álcool vêm de famílias com maior renda e onde algum dos irmãos faz uso freqüente de álcool ou drogas. Parece que estes estudantes experimentam em suas famílias um sistema social que reforça o comportamento do uso de álcool. Ao 
mesmo tempo, dentro da universidade, estes estudantes tendem a formar suas redes sociais com outros estudantes que apresentam os mesmos comportamentos e atitudes com relação ao uso de álcool e drogas.

Outra categoria de fatores muito importante e extensivamente estudada é a influência dos amigos com relação iniciação e manutenção do uso de álcool e drogas (MUSHER-EIZENMAN et al., 2003, BORSARI E CAREY, 2001; KAVHARI, 1993; KANDEL, 1985). Esta influência pode ser direta, através da oferta, compra e encorajamento para o uso de bebida ou drogas, ou indireta através do compartilhamento de normas que valorizam e reforçam o comportamento de usar alguma substância. Shilts (1991) afirma que " $88 \%$ das pessoas que abusam de drogas possuem amigos que também abusam de drogas". No entanto, sobre o poder desta influência afirma: "adolescentes que usam drogas em respostas à pressão dos amigos ou em situações de interação social possuem mais facilidade de parar de usá-las que aqueles que as usam por razões psicológicas“. Parece ser esse o caso muitas vezes do uso de álcool e drogas pelos estudantes universitários. A influência do grupo de amigos e as situações de interação social como festas, viagens ou passar o tempo livre dentro da universidade muitas vezes inclui e valoriza o uso de álcool e outras drogas. Uma parcela destes estudantes, ao serem expostos a estas experiências, vai encontrar recompensas psicológicas que farão com que este consumo se intensifique aumentando os riscos para conseqüências adversas.

Trice and Beyer (1977) utilizam a expressão "Propriedades sociológicas das drogas" para se referir a esta pressão dos amigos que compõem a rede social dos estudantes. Estes autores defendem a idéia de que "estas propriedades podem contribuir para a dependência através do suporte coletivo para o uso de drogas que é extremamente forte e reforçador, 
pois se relaciona a aceitação do indivíduo no grupo". Analisando dados obtidos entre estudantes de graduação os autores mostram que "estudantes tendem a aceitar mais usuário de álcool moderado ou "social" do que o abstêmio ou bebedor pesado". Aparentemente durante o curso universitário abster-se do uso de álcool é uma difícil decisão, pois vai contra as normas compartilhadas pelos estudantes e implica em algum grau de exclusão social. A partir destas reflexões talvez fique mais claro entender o porque freqüentar os centros acadêmicos é um fator de risco para o uso corrente de álcool. Basicamente pelas normas sociais compartilhadas onde beber é um comportamento aceito e valorizado dentro daquele ambiente de lazer.

Outro dado interessante é que os estudantes que aparentemente possuem menos tempo livre, pois trabalham ou se dedicam a outras atividades que fazem com que o tempo de lazer em casa também seja ocupado com o estudo ou descanso, apresentam maior risco para o uso corrente de álcool. Talvez se esteja falando aqui de um perfil de estudante cujo estilo de vida seja de maior independência financeira com relação à família. O comportamento do uso do álcool pode ser parte deste estilo e estar associado a uma maneira de lidar com o stress e com o cansaço nas horas livres, que o maior poder aquisitivo e a maior independência da família podem facilitar.

\section{CONCLUSÕES}

7.1 Ao comparar os padrões de uso de drogas entre os alunos de graduação da USP entre 1996 e 2001, observou-se aumento estatisticamente significativo de: uso na vida de: álcool, de 88,5\% para 91,9\%; tabaco, de 42,8\% para 50,5\%; maconha, de $31,1 \%$ para $35,3 \%$; alucinógenos, de $6,1 \%$ para $11,4 \%$; anfetaminas, $4,8 \%$ para 
9,0\%; anticolinérgicos, de 1,1\% para 2,9\%; inalantes, de $17,9 \%$ para $24,5 \%$; barbitúricos, de 1,0\% para 1,7\% e ilegais de 39,4\% para 45,1\%; uso nos últimos 12 meses de: maconha, de 19,9\% para 22,8\%; alucinógenos, de 3,5\% para 5,0\%; anfetaminas, de 2,7\% para 5,3\%; inalantes, de $8,8 \%$ para $13,5 \%$ e ilegais de $28 \%$ para $31,2 \%$; uso nos últimos 30 dias de: maconha, de 14,9\% para 16,9\%; anfetaminas, de 2,2\% para 3,4\%; inalantes, de 4,1\% para 6,5\% e ilegais de $17,3 \%$ para $21,8 \%$.

As prevalências de drogas entre alunos da graduação da USP continuam altas se comparadas às encontradas na população em geral e estudantes de primeiro e segundo graus brasileiros. No entanto, são semelhantes às encontradas entre estudantes de outras universidades brasileiras.

7.2 Ao comparar as atitudes dos alunos com relação a experimentar e fazer uso regular de drogas entre 1996 e 2001, observou-se que em 2001 aumentou a aprovação para o uso experimental de: cocaína, crack, anfetaminas e inalantes; e para o uso regular de: maconha, cocaína, crack, anfetaminas e inalantes.

Apesar deste aumento, as maiores prevalências de aprovação para o uso experimental, em 2001, são para álcool, tabaco e maconha. Os maiores índices de desaprovação referem-se ao crack e a cocaína. Os maiores índices de aprovação para o uso regular de drogas referem-se ao álcool, tabaco e maconha. E os maiores índices de desaprovação referem-se às drogas ilícitas exceto maconha.

7.3 Comparando-se o uso de drogas entre os alunos das três áreas de estudo: Biológicas, Exatas e Humanas, observa-se que as maiores prevalências para a maioria das drogas foram encontradas entre os alunos da área de Humanas; os alunos da área de Biológicas apresentam maior consumo recente de álcool e 
inalantes do que os alunos das outras duas áreas e os alunos da área de Exatas foram os que apresentaram menores prevalências para a maioria das drogas.

Comparando-se o uso de drogas entre os alunos do sexo masculino e feminino, observa-se que os homens fazem mais uso de: álcool, inalantes, anabolizantes, crack, cocaína, alucinógenos e maconha. As mulheres fazem mais uso de: tranqüilizantes, anfetaminas e opiáceos.

7.4 Aspectos familiares, normas favoráveis ao uso de álcool e drogas compartilhadas com as redes sociais que os estudantes formam dentro da universidade e uso pessoal e dos amigos de álcool e drogas são variáveis que mostraram associação positiva com o uso corrente de álcool e recente de drogas ilegais.

Uma possível forma de prevenção é atuar nos espaços de interação social dos estudantes de forma a minimizar o uso excessivo de bebidas alcoólicas e as conseqüências adversas deste uso através de estratégias de redução de danos. Outro aspecto importante é o investimento na transformação das normas sociais com relação ao consumo regular principalmente de álcool, tabaco, maconha e inalantes que são as drogas mais consumidas e mais aceitas dentro do ambiente universitário. Estudantes com mais fracos suportes sociais, menos engajamentos e vínculos a atividades coletivas dentro da universidade são os que apresentam maiores riscos para o desenvolvimento do abuso e dependência de álcool e drogas. Estudantes pertencentes a redes sociais onde o uso de álcool e drogas são mais valorizados são os que possuem mais riscos para episódios de intoxicação aguda e envolvimento em acidentes de automóvel e outras formas de injúria. 


\section{REFERÊNCIAS BIBLIOGRÁFICAS}

ANDRADE, A.G.; BASSIT, A.Z; MESQUITA, A.M. et al. Prevalência do uso de drogas entre alunos da Faculdade de Medicina da Universidade de São Paulo. Revista ABP-APAL, v. 17, n. 2, pp. 41-46, 1995.

ANDRADE, A.G.; BASSIT A.Z.; KERR-CORREAA, F. et al. Fatores de risco associados ao uso de álcool e drogas na vida, entre estudantes de Medicina do Estado de São Paulo. Revista ABP-APAL, v. 19, n. 4, pp. 117-126, 1996.

ANDRADE, A. G.; QUEIROZ, S.; VILLABOIM, R. C. M. et al. Uso de álcool e drogas em alunos de graduação da Universidade de São Paulo. Revista ABP-APAL, v. 19, n. 2, pp. 53-59, 1997.

ANDRADE, A. G. Consumo de drogas entre alunos da Universidade de São Paulo. Tese apresentada à Faculdade de Medicina da Universidade de São Paulo para obtenção do Título de Professor Livre-Docente junto ao Departamento de Psiquiatria. São Paulo, 1997.

ARAP S.S., SCHULTZ R.R., DUALIBI K. Estudo Epidemiológico do Uso de Drogas por Estudantes Universitários em Faculdades da Zona Sul de São Paulo. XIII Congresso Acadêmico Médico da Faculdade de Medicina de Santo Amaro, 1992.

BAUDELAIRE, C. Os Paraísos Artificiais. O ópio e Poema do haxixe. Porto Alegre. L\&Pm Editores Ltda, 1982.

BACHMAN, J.G., JOHNSTON, L.D., O'MALLEY, P.M. Explaining recent increases in students' marijuana use: impacts of perceived risks and disapproval, 1976 through 1996. American Journal of Public Health, v. 88 n. 6 pp. 887-892, 1998.

BATES, M.E., LABOUVIE, E.W. Adolescent risk factors and the prediction of persistent alcohol and drug use into adulthood. Alcohol Clin Exp Res, v. 21, n. 5, pp. 944-958, 1997.

BAUMAN, A., PHONGSAVAN, P. Epidemiology of substance use in adolescence: prevalence, trends and policy implications. Drug and Alcohol Dependence, v. 55, pp. 187-207, 1999.

BENJAMÍN, W. Haxixe. São Paulo. Editora Brasiliense, S. A., 1984.

BERKMAN LF, GLASS T. Social integration, social networks, social support, and health. In Berkman LF, Kawachi I. Social Epidemiology. New York: Oxford University Press, 391p., 2000.

BERTOLOTE, J.M. Glossário de Termos de Psiquiatria e Saúde Mental da CID10 e seus derivados. Porto Alegre, Artes Médicas, 1997.

BORSARI, B., CAREY, K.B. Peer influences on college drinking: a review of the research. Journal of Substance Abuse, v. 13, pp. 391-424, 2001. 
BOSKOWITZ, E.P. ET AL. Uso de Drogas Psicoativas em Estudantes Universitários de São José do Rio Preto - São Paulo. (mimeo),1990.

BRAU, J.L. Historia de las Drogas. Barcelona. Editorial Bruguera S.A., 1974.

BRENES, L.F.V. et al. Drogas llícitas entre Universitários. Revista da Associação Médica do Rio Grande do Sul, v. 30, pp. 140-143,1986.

BUCHER, R. e TOTUGUI, M.L. Conocimiento y Uso de Drogas entre Alunos de Brasília. Acta Psiquiatrica y Psicologica de la America Latina, v. 34, pp. 113-126, 1988.

CARLINI, E. A.; GALDURÓZ, J. C.; NOTO, A. R.; NAPPO, S.A. I Levantamento Domiciliar sobre o Uso de Drogas Psicotrópicas no Brasil: Estudo envolvendo as 107 Maiores Cidades do País - Centro Brasileiro de Informações sobre Drogas Psicotrópicas (CEBRID). Departamento de Psicobiologia da Universidade Federal de São Paulo, 2001.

CARVALHO, F.V. Drug Use Among University Students in the State of São Paulo, Brazil. Bulletin on Narcotics, v. 38, pp. 37-39, 1986.

CHEN, K. AND KANDEL, D.B. Predictors of cessation of marijuana use: an event history analysis. Drug and Alcohol Dependence, v. 50, pp. 109-121, 1998.

CLARCK, W.B. E MIDANIK, L. Alcohol use and alcohol problems among, U. S. adults: Results of the 1979 National Survey, 1982. In: SCHALL, M. KEMENY, A. AND MALTZMAN, I. Factors Associated with Alcohol Use in University Students. Journal of Studies on Alcohol, v. 53, n. 2, 1992.

Classificação de Transtornos Mentais e de Comportamento da CID-10: Descrições Clínicas e Diretrizes Diagnósticas. OMS. Tradução Dorgival Caetano - Porto Alegre: Artes Médicas, 1993.

CLONINGER, C. R., SIGVARDSSON, S. BOHMAN, M. Inheritance of alcohol abuse. Arch Gen Psychiatry, v. 38, pp. 861-868, 1981. In PATTON, L..H. Adolescent substance abuse. Risk factors and protective factors. Pediatr Clin North Am, v. 42, n. 2, pp. 283-93, April,1995.

DSM-IV - Manual diagnóstico e estatístico de transtornos mentais. Tradução: Dayse Batista. 4 ed. - Porto Alegre: Artes Médicas, 1995.

ELIADE, M. O Xamanismo e as Técnicas Arcaicas do Êxtase. São Paulo, Martins Fontes, 1998a.

ELIADE, M. Tratado de História das Religiões. São Paulo. Martins Fontes, 1998b.

GALDURÓZ, J.C.F. ; NOTO A.R.; CARLINI, E.A. - IV Levantamento sobre o Uso de Drogas entre Estudantes de $1^{\circ}$ e $2^{\circ}$ graus em 10 Capitais Brasileiras -1997 . Centro Brasileiro de Informações sobre Drogas Psicotrópicas (CEBRID). Departamento de Psicobiologia da Universidade Federal de São Paulo.1997. 
GLOBAL DRUG ABUSE PATTERNS AND TRENDS, 1999. Disponível: em http://www.undcp.org/reasearch.html. Site acessado em 05/02/02

GLOBAL ILLICIT DRUG TRENDS, 2002. Disponível em

http://www.undcp.org/reasearch.html. Site acessado em 05/02/02

GLOBAL ILLICIT DRUG TRENDS, 2003. Disponível em

http://www.undcp.org/reasearch.html. Site acessado em 05/11/03.

GOLD, M. S. The Neurobiology of Addictive Disorders. The Role of Dopamine, Endorphin, and Serotonin. In: MILLER, N.S. The Principles and Practice of Addictions in Psychiatry. Pennsylvania. W.B. Saunders Company, 1997.

GORDIS, L. Epidemiology. W.B. Saunders Company, Pennsylvania, 2nd ed., pp. 155; 2000.

GORENSTEIN, C. Uso de Psicoestimulantes e Energizantes por Universitários. Revista da Associação Médica Brasileira, v. 29, pp. 45-46,1983.

GRISSO, J. A . Making Comparisons. The Lancet, 342, July 17. 1993

IBGE, INSTITUTO BRASILEIRO DE GEOGRAFIA E ESTATístiCA. Censo Demográfico - 2000: Primeiros Resultados da Amostra. Disponível em http://www.ibge.gov.br/. Site acessado em março de 2002.

KANDEL, D.B. e LOGAN, J.A. Patterns of Drug Use from Adolescence to Young Adulthood: 1. Periods of Risk for Initiation, Continued Use, and Discontinuation. American Journal of Public Health, v. 74, n. 7, pp. 660 - 666, 1984.

KANDEL, D.B. On processes of peer influences in adolescent drug use: a developmental perspective. Advances in Alcohol and Substance abuse, v. 4 n.3-4, pp. 139-163. 1985.

KAUFFMAN, S.E.; SILVER, P; POULIN, J. Gender differences in attitudes toward alcohol, tobacco, and other drugs. Social Work, v. 42, n. 3, pp. 231-241, May, 1997.

KELSEY, J. et Al. "Cross-Sectional and Other Types of Studies" in Epidemiology and Biostatistics, 1996.

KERR-CORRÊA, F.; DALBEN, I.; TRINCA, L.A .; SIMÃO, M.O.; MATTOS, P.F.; RAMOS-CERQUEIRA, A.T.; MENDES, A.A. I Levantamento do Uso de Álcool e de Drogas e das Condições Gerais de Vida dos Estudantes da Unesp (1998). Fundação VUNESP - 2001.

KHAVARI, K. A. Interpesonal influence in college students' initial use of alcohol and drugs - the role of friends, self, parents, doctors and dealers. The International Journal of the Addictions, v. 28, n. 4, pp. 377-388, 1993.

KILPATRICK, D.G., ACIERNO, R., SAUNDERS, B., RESNICK, H.S., BEST, C.L. Risk factors for adolescent substance abuse and dependence: data from a national sample. Journal of Consulting and Clinical Psychology, v. 68, n. 1, pp. 19-30, 2000. 
KNIGHT, J.R., WECHSLER, H., KUO, M., SEIBRING, M., WEITZMAN E.R., SCHUCKIT, M. Alcohol abuse and dependence among U.S. college students. Journal of Studies of Alcohol, v. 63, n 3 pp. 263-270, 2002.

LANIER, C.A.; NICHOLSON, T.; DUNCAN, D. Drug use and mental well being among a sample of undergraduate and graduate college students. Journal of Drug Education, v. 31, n. 1. pp. 239-248, 2001.

LEEMAN, R. F. WAPNER, S. Some factors involved in alcohol consumption of firstyear undergraduates. Journal of Drug Education, v. 31, n. 3. pp. 249-262, 2001.

MAGALHÃES, M.P.; BARROS, R.S.; SILVA, M.T.A. Uso de Drogas entre Universitários: A Experiência com Maconha como Fator Delimitante. Revista ABPAPAL, v. 13, n. 3: pp. 97-104, 1991.

MESQUITA, A.M.; ANDRADE AG; ANTHONY, J.C.(1992). Alcohol and Drug Use Among Medical Students at the University of São Paulo, Brazil, apresentado na Association for Medical Education and Research in Substance Abuse National Conference, Bethesda-Md, Novembro 13, 1992.

MESQUITA, A.M., LARANJEIRA, R. AND DUNN, J. Psychoative drug use by medical students: a review of the national and international literature. São Paulo Medical Journal/RPM. v. 115, n. 1, pp. 1356-1365, 1997.

MONITORING THE FUTURE, 2001.Tracking Trends in Teen Drug Abuse over the years. NIDA Notes, v.14, n. 1. Disponível em www.nida.nih.gov/drugpages/stats.html. Acessado em 05/01/02.

MOURÃO, L. N. G. Uso de drogas entre alunos de quatro faculdades da UFMG: prevalência e comparação com amostra da USP. Dissertação apresentada à Faculdade de Medicina da Universidade de São Paulo para a obtenção do Título de Mestre em Medicina. São Paulo, 2001.

MURAD, J.E. Drug Abuse among Students in the State of Minas Gerais, Brazil. Bulletin on Narcotics, v. 31, pp. 49-58, 1979.

MUSHER-EIZENMAN, D., HOLUB, S., ARNETT, M. Attitude and peer influences on adolescent substance use: the moderating effect of age, sex, and substance. J. Drug Education, v. 33, n. 1, pp. 1-23, 2003.

NETER, J., WASSERMAN, W., KUTNER, M.H. Applied linear statistical models: regression analysis of variance experimental design. 4ed. Homewood: Richard D. Irwing, 1408p. 1996.

NEWCOMB, M.D. Psychosocial Predictors and consequences of drug use: a developmental prospective within a prospective study. Journal of Addictive Diseases, v. 16, n. 1, pp. 51-89, 1997.

NOTO A.R., NAIPO S., GALDURÓZ J.C.F., MATTEI R., CARLINI E.A. IV Levantamento sobre o uso de drogas entre crianças e adolescentes em situação de rua de seis capitais brasileiras - CEBRID - UNIFESP, São Paulo, 1997. 
O'MALLEY, P.M., JOHNSTON, L.D. Epidemiology of alcohol and other drug use among American college students. J Stud Alcohol Suppl, v. 14 pp. 23-39, 2002.

PERKINS, H. Stress-Motivated Drinking in Collegiate and Poscollegiate: Young Adulthood: Life Course and Gender Patterns. Journal of Student Alcohol, v. 60 n. 2, pp. 219-227, 1999. In: LANIER, C.A.; NICHOLSON,T.; DUNCAN, D. Drug use and mental well being among a sample of undergraduate and graduate college students. Journal of Drug Education, v. 31, n. 1. pp. 239-248, 2001.

PLOTNIK, R. Utilização de Psicotrópicos por Estudantes Universitários. Revista Pesquisa Médica v. 20, pp 109-113, 1986.

POLO, M. O livro das Maravilhas. Porto Alegre. L\&PM /editores Ltda, 1999.

POPE, H.G., IONESCU-PIOGGIA, M., POPE, K.W. Drug use and life style among college undergraduates: a 30-year longitudinal study. Am J Psychiatry, v. 158 pp. 1519-1521, 2001.

PRENDERGAST ML. Substance use and abuse among college students: a review of recent literature. Journal of American College Health, v. 43, 1994.

PRODUSP - Programa de Prevenção e Tratamento ao Uso de Drogas entre Alunos, Funcionário e Professores da USP. Relatório de Atividades, 2003. GREA - Grupo Interdisciplinar de Estudos de Álcool e Drogas. Departamento de Psiquiatria da Faculdade de Medicina da USP.

QUEIROZ, S., Fatores Relacionados ao Uso de Drogas e Condições de Risco entre Alunos de Graduação da Universidade de São Paulo. Tese de Doutorado Apresentada ao Departamento de Saúde Materno-Infantil da Faculdade de saúde Pública da Universidade de São Paulo para obtenção do grau de Doutor em Saúde Pública. São Paulo, 2000.

QUINCEY, T. Confissões de um comedor de Ópio. Porto Alegre. L\&PM Editores Ltda, 1982.

RAY, O.S. Drugs, society \& human behavior. Oakley Ray and Charles Ksir org. $5^{\text {th }}$ Ed. Times Mirror/ mosby - College Publishing, 1990.

READ, J.P., WOOD, M.K., DAVIDOFF, O.J., MCLACKEN, J., CAMPBELL, J.F. Making the transition from high school to college: the role of alcohol-related social influence factors in students ' drinking. Substance Abuse, v. 23 pp. 53-65, 2002.

SCHALL, M., KEMENY, A., MALTZMAN, I. Factors associated with alcohol use in university students. Journal of Studies on Alcohol, v. 53, n. 2, pp. 122-136, 1992.

SCHULTES, R. E. , HOFMANN, A . Plantas de los Dioses - Orígenes del uso de los alucinógenos. México. Fundo de Cultura Econômica, 2000.

SHER, K. J., WAILTZER, K. S., WOOD, P. K. et al. Characteristics of children of alcoholics: putative risk factors, substance use and abuse, and psychopatology. $J$ Abnorm Psychol, v. 100, n. 4. pp. 427 -448, 1991. In PATTON, L..H. Adolescent substance abuse. Risk factors and protective factors. Pediatr Clin North Am, v. 42 , n. 2, pp. 283-93, April,1995. 
SHILTS, L. The relationship of early adolescent substance use to extracurricular activities, peer influence, and personal attitudes. Adolescence, v. 26, n. 103, pp. 613617. In PATTON, L..H. Adolescent substance abuse. Risk factors and protective factors. Pediatr Clin North Am, v. 42, n. 2, pp. 283-93, April,1995.

SILVA, R. Caracterização das Famílias de Jovens Infratores da FEBEM/SP. Documento disponível na própria instituição -coordenadoria de pesquisa, 1997.

SIMONI-WASTILA, L. The use of abusable prescription drugs: the role of gender. Journal of Women's Health \& Gender-Based Medicine, v. 9, n. 3, pp. 289-97, 2000.

STROTE, J. LEE, J.E. AND WECHSLER, H. Increasing MDMA Use Among College Students: Results of a National Survey. Journal of Adolescent Health, v. 20, pp. 6472, 2002.

SWADI, H. Individual risk factors for adolescent substance use. Drug and Alcohol Dependence, v. 55, pp. 209-224, 1999.

SZALAY, L.B., INN, A., DOHERTY, K.T. Social influences: effects of the social environment on the use of alcohol and other drugs. Substance Use \& Misuse, v. 31 n. 3, pp. 343-373, 1996.

SZEGO, T. et al. Levantamento Epidemiológico sobre o Vício de Fumar entre Estudantes de Medicina no Estado de São Paulo. Revista da Associação Médica Brasileira 31, pp 13-16, 1985.

TRACI, H.M., BEYER, J.M. A sociological property of drugs. Acceptance of users of alcohol and other drugs among university undergraduates. Journal of Studies on Alcohol, v. 38, n. 1, pp. 58-74, 1977.

UNODC. Demand Reduction - A Glossary of Terms. OMS, New York, 2000. http://www.undcp.org/pdf/report_2000-11-30_1.pdf. Site acessado em 05/08/2002.

UNODC. Global Illicit Drug Trends 2002. OMS, New York, 2002. http://www.undcp.org/global_illicit_drug_trends.html. Site acessado em 27/07/2002.

UNODC. Comission on Narcotic Drugs of the Economic and Social Council of the United Nations Single Convention on Narcotic Drugs, 1961. http://www.unodc.org/pdt/convention_1961_en.pdf. Site acessado em 20/05/2004.

VEGA, W. A., AGUILAR-GAXIOLA S., ANDRADE, L., BIJL R., BORGES G., CARAVEO-ANDUAGA, J. J., DEWIT, D. J., HEERINGA, S. G., KESSLER R. C., KOLODY B., MERIKANGAS, K. R., MOLNAR, B. E., WALTERS, E. E., WARNER L. A., WITTCHEN, H.U. Prevalence and age of onset for drug use in seven international sites: results from the international consortium of psychiatric epidemiology. Drug and Alcohol Dependence, v.68, pp. 285-297. 2002. 
VELHO, G. A dimensão cultural e política dos mundos das drogas. In ZALUAR, A . Drogas e Cidadania, Redução ou Redução de Riscos; São Paulo. Editora Brasilense., 1994.

WEBB, E., ASHTON, H., KELLY, P. KAMALI, F. Patterns of alcohol consumption, smoking and illicit drug use in British university students: interfaculty comparisons. Drug and Alcohol Dependence, v. 47, pp. 145-153, 1997.

WECHSLER, H., DOWDALL, G.W., DAVEMPORT, A., RIMM, E.B. A Genderspecific measure of binge drinking among college students. American Journal of Public Health, v. 85, n. 7, pp. 982-985, 1995.

WECHSLER, H., MOLNAR, B.E., DAVENPORT, A.E., BAER, J.S. College alcohol use: a full or empty glass? College Alcohol Use, v. 47, May, 1999.

WORLD DRUG REPORT. OMS, New York, 2002. http://www.undcp.org/world_drug_report.html. Site acessado em 27/07/2002.

YU, J. Negative consequences of alcohol use among college students: victims of victimizers? Journal of Drug Education, v. 31, n. 3, pp. 271-287, 2001.

ZANINI, A.C. et al. Concepts and Use of Psychoactive Drugs by University Students in the São Paulo Area. Drug Forum, v. 6, pp. 85-99, 1977-78. 